No.1732

December 2020

\title{
Heterogeneity in criminal behavior after child birth: the role of ethnicity
}

Kabir Dasgupta

André Diegmann

Tom Kirchmaier

Alexander Plum 


\begin{abstract}
This paper documents behavioral differences in parental criminality between majority and minority ethnic groups after child birth. The particular effect we exploit is that of the gender of the first-born child on fathers' convictions rates. Based on detailed judicial and demographic data from New Zealand, we first show that the previously documented inverse relationship between having a son and father's criminal behaviour holds across the average of the population. However, when splitting the fathers' sample by ethnicity, the effect appears to be entirely driven by the white part of the population and that there is no effect on the native Māori. The strong ethnic divide is observed along many dimensions and challenges the implicitly made assumption in the economics of crime literature that findings are universally applicable across cultures and race.
\end{abstract}

Key words: crime research, racial bias

JEL codes: K42; K49; L38

This paper was produced as part of the Centre's Community Wellbeing Programme. The Centre for Economic Performance is financed by the Economic and Social Research Council.

\title{
Acknowledgements
}

We are grateful to Jeff Grogger for very helpful comments and discussions. Many thanks to Savannah Kochinke for excellent research assistance. All errors are our own.

Kabir Dasgupta, Auckland University of Technology. André Diegmann, Halle Institute for Economic Research, Centre for European Economic Research. Tom Kirchmaier, Centre for Economic Performance, London School of Economics and Copenhagen Business School. Alexander Plum, Auckland University of Technology.

Published by

Centre for Economic Performance

London School of Economics and Political Science

Houghton Street

London WC2A 2AE

All rights reserved. No part of this publication may be reproduced, stored in a retrieval system or transmitted in any form or by any means without the prior permission in writing of the publisher nor be issued to the public or circulated in any form other than that in which it is published.

Requests for permission to reproduce any article or part of the Working Paper should be sent to the editor at the above address.

(c) K. Dasgupta, A. Diegmann, T. Kirchmaier and A. Plum, submitted 2020. 


\section{Introduction}

Karl Popper who worked on the philosophy of science has taught us that a theory can be disproved by a counter-example (Popper 2013). Following Popper, we aim to show that ethnicity is an important differentiator in behaviour, with implications for the external validity of research. In our example, we document strong behavioral differences in criminal behavior between majority and minority ethnic groups, something that is typically ignored in the literature. This paper is based on detailed administrative data from New Zealand, and exploits a novel empirical design proposed by Dustmann and Landers $\varnothing$ (2018) by using the random variation in the gender of the first child.

Our study builds on earlier research that has shown that important events in a man's life, such as marriage or fatherhood, could lead them to refrain from or even take-up criminal activities (Sampson and Laub 1990, Corman et al. 2011). Trying to causally interpret the effect of these so called 'turning points' can be challenging as these events aren't random. A turning point can be jointly correlated with the same unobserved characteristics that provoke people to commit crimes. This can result in selection bias or simultaneity concerns when trying to analyse criminal behavior decisions.

The age-crime curve peaks for men in their late-teens and early-twenties, making young men one of the highest offending cohorts (Farrington 1986, Loeber 2012). Having a criminal record at a young age in the form of arrest or conviction can have a long-term scarring impact on future labor market prospects. The stigma of conviction can negatively affect employment opportunities and can undermine the acquisition of human and social capital (Western et al. 2001). Following rational choice theory, individuals who face adverse labor market opportunities that restrict access to legitimate ways of earning wage are more likely turn to crime (Becker 1968), thereby creating a vicious cycle that can be difficult to exit.

Therefore, it is important to understand the mechanisms that drive criminal behaviour among the youth population so that communities can more effectively design intervention strategies to deter crime. In this paper, we aim to show that these initiatives might be ineffective if they are not sufficiently tailored to account for ethnic sub-groups, especially in societies where ethnic minorities constitute a sizeable share of the overall population.

Young fathers are susceptible to various socio-economic risks that can adversely affect their ability to provide for their families. For instance, not only are young fathers more likely to drop out of school and face poorer employment prospects (Weinman et al. 2002), they are also at a greater risk of being involved in illegal 
activities (Larson et al. 1996, Weinman et al. 2002, Weinmann et al. 2006). As such, young fathers often represent a socially vulnerable group for whom early crime prevention strategies can have the potential to reap long-term gains, both at the individual as well as at the family-level. Grogger (1992) finds that an arrest record can contribute to persistent joblessness, and that it explains up to two-thirds of the employment differential between young white and black men. Incarceration and prison sentences also negatively affect post-release earnings (Grogger 1995). However, Bhuller et al. (2020) show that incarceration can improve employability and discourage criminal behavior for individuals who tend to have low labor market aspirations.

Previously employed incarcerated individuals experience lasting detrimental effects on employment. These adverse labor market outcomes along with the associated risk factors for young fathers can translate to their children as well. However, the intergenerational spillovers of adverse socio-economic consequences can vary across societies with different cultures and legislative framework. Farrington et al. (1996) document the inter-generational persistence of crime in a study of Londonbased males. Their study finds that for fathers with previous convictions, $63 \%$ of their sons also held a conviction, while the corresponding figure was only $30 \%$ for those with no prior conviction. Drawing evidence from Sweden, Dobbie et al. (2018) show that parental incarceration leads to a $17 \%$ points increase in teen crime, $7 \%$ points increase in teen pregnancy and a $27 \%$ points decrease in employment for their offspring's. These effects are concentrated amongst disadvantaged families. However using Norwegian data, Bhuller et al. (2018) find that paternal incarceration does not affect a child's criminal activity or school performance. Finally, contrary to the popular belief, in a recent study based on evidence from the state of Ohio, Norris et al. (2020) show that parental incarceration leads to a reduction in children's involvement in criminal activities. The contrasting finding is quantified by a decrease in a child's likelihood of being incarcerated by $4.9 \%$ points and the effects seem to be more prominent among children from poor neighborhoods who are usually at a greater risk of witnessing maternal incarceration. Importantly, the observed heterogeneity in the estimated relationships between parental incarceration and child outcomes highlights the potential existence of institutional differences and variation in public attitude across geographic regions.

A growing literature examines how child gender affects parental treatments and thereby contributes to differences in children's long-term outcomes. ${ }^{1}$ There have been several prominent papers in this literature that derive conclusions based on

\footnotetext{
${ }^{1}$ For an overview, see Lundberg (2005).
} 
pooled regressions, which account for the relevance of individuals' demographic identity such as race or ethnicity by treating those characteristics only as a control. Our study demonstrates that there can be important behavioral differences across different demographic and cultural groups that may often be disregarded in population-based pooled analyses. For instance, Dahl and Moretti (2008) and Mammen (2008) conclude that women with first-born girls are less likely to marry and more likely to divorce. Heterogeneous estimates by race, however, show that the marriage effect is driven by black women, whereas the divorce effect comes from the white part of the population. Dustmann and Landers $\varnothing$ (2018) show that young fathers reduce their criminal activity if the first-born child is a boy and this has implications on criminality of the fathers' peers as well. The sample in Dustmann and Landersø (2018)'s study consists of $14.2 \%$ of non-native fathers. Even though sample size restrictions renders a causal analysis unfeasible, non-native fathers are likely to adjust their behavior differently. In fact, we show that ethnic groups adjust differently suggesting different possible channels and implications to design policies. We argue that behavioral differences by ethnicity should be considered with more caution.

We contribute to the literature by looking into the varying effects of ethnicity, based on data from New Zealand (NZ). Ethnicity is an important consideration when designing policy, one that is particularly salient given the current Black Lives Matter (BLM) debate. Our findings that the effects differ by ethnicity imply that there cannot be a 'one-size-fits-all' policy response and therefore question the efficacy of several existing crime reduction programs in place.

In New Zealand, the majority (70\%) of the population is of European descent while Māori makes up the largest minority population at 16.5\% (StatsNZ 2019). Yet, Māori youth face an "overrepresentation in negative social statistics" (Elkington 2017, Karena 2012, Pihama et al. 2014, Kingi 2011, Quince 2007) and are often portrayed as "deviant and unable to help themselves" (Elkington 2017, Groot 2006, Johnston and Pihama 1994, Wall 1997). The literature attributes these stereotypes to "systemic disadvantages" and risk factors that Māoris are disproportionately exposed to compared to the non-Māori groups (Elkington 2017, Durie 1994, Dyall 1997). These stereotypes also contribute to what some describe as 'ethnic toxicity' in New Zealand's criminal justice system. Despite being a minority group, Māori represents almost $56 \%$ of the prison population (Pratt 2006, McIntosh and Workman 2017). This is even more pronounced than in the U.S., where AfricanAmericans represent $33 \%$ of the prison population and approximately $13 \%$ of the overall population (BJS 2019). 
This paper is structured as follows: In Section 2, we describe our data, sample, and the criminal justice setting in New Zealand. In Section 3, we present the descriptive statistics for crime and young fatherhood in New Zealand, by type of conviction and ethnic group. We then discuss our empirical strategy to identify the effects of the gender of the first child on criminal and labor market outcomes in Section 4. We present our results for convictions on the gender of the child in Section 5 and discuss further labor market and social outcomes in Section 6 . And finally, in Section 7, we discuss the broader implications of accounting for racial and ethnic disparities in research.

\section{Data and sample selection}

Our study of the effect of the child's gender on criminal behaviour of the father is based on various administrative datasets that are all hosted on the Integrated Data Infrastructure (IDI). Administered by Statistics New Zealand (Stats NZ), the IDI is a large research database that holds complete datasets from various public agencies and organisations. The individuals are linked across all datasets by a unique confidentialised individual identifier.

The Department of Internal Affairs (DIA) hosts the birth register of the entire New Zealand population (dating back to the $19^{\text {th }}$ century). The birth register provides birth date information of individuals at the monthly level, but more importantly enables us to link parents to their children. ${ }^{2}$ We define our main sample of young fathers as all males who father their first child between the age of 18 and 21 . We choose 18 as the lower age threshold because we evaluate the criminal trajectories of young fathers, which requires us to observe at least two years of pre-birth crime outcomes. In addition, the youth justice system is responsible for offenders aged 14-16 years for whom data access is restricted. ${ }^{3}$

Most importantly, our crime data comes from the Ministry of Justice's (MoJ) register of court charges that contains records of all charges processed by criminal courts in New Zealand since 1992. Each charge includes information on the offence type, the date of the offence, when the charge was filed, and when the outcome of the criminal proceedings was declared. A criminal charge may be filed by the

\footnotetext{
${ }^{2}$ One caveat is that we are not able to differentiate between biological and adopted children. However, in contrast to other countries, adoptions in New Zealand where there is a legal transfer of parenting rights and responsibilities from birth to adoptive parents are very rare. For example, in 2010 there were almost 64 thousand life births (StatsNZ 2020) and only 193 adoptions (MoJ $2020 a$ ).

${ }^{3}$ Depending on the seriousness of offence, 17 year old either go through the youth (less serious) or the adult (more serious) criminal justice system (MoJ 2020b).
} 
Police, the Corrections, local authorities, or other government agencies. Usually, each charge refers to one offence. To give an example, an individual may attend court on one occasion for three charges of burglary and one of assault, which would result in a total of four charges. In addition, the dataset holds information on the outcome of the charge, e.g. whether the individual was convicted or acquitted. As a conviction can receive multiple sentences, the dataset also holds information on the five most serious sentences. The seriousness ranking follows from the Australian and New Zealand Society of Criminology (ANZSOC) code, which allows us to identify the most serious sentence imposed. These charges includes (hierarchically ranked) imprisonment, home detention, community detention, intensive supervision, community work, supervision, monetary fines, deferment, and others. ${ }^{4}$

Based on the seriousness of a conviction, we classify our sample into the following two groups:

- Serious sentence: Most serious sentence is imprisonment, home or community detention, community work, supervision.

- Non-serious sentence: Most serious sentence is a fine, deferment or other.

For additional individual-level information required for our analysis, we link our sample of young fathers to several administrative datasets. First, we derive the fathers' ethnicity information ${ }^{5}$ from the Stats NZ-generated Personal Details file, which incorporates demographic characteristics of all individuals present in the IDI. Next we include monthly information on wages and benefits by linking our sample to the Inland Revenue's tax records that document employment-related information of the whole of New Zealand's work force. To ensure that a person is physically present inside New Zealand and is not deceased during the period of our analysis, we utilize the border movement data provided by the Ministry of Business, Innovation and Employment and DIA's death register, respectively. The DIA data further provides important family formation indicators such as the date of marriage or civil union. For information on educational background, we link our sample to the tertiary education data provided by the Ministry of Education. This allows us to construct individual-level indicators of enrollment in tertiary qualifications. Finally,

\footnotetext{
${ }^{4}$ Individuals with no sentence recorded as highest sentence are dropped from the sample.

${ }^{5}$ The ethnicity variable is derived from multiple sources within the IDI using a set of specific rules. Ethnicity variables are an 'ever-indicator' that shows all ethnicity an identity has recorded across data collections over time. It is possible that an individual states up to six different ethnic groups (NZ European, Māori, Pacific, Asian, Middle Eastern/Latin American/African (MELAA), and other). For our study, we restrict the sample to those men with a single ethnicity on either NZ European or Māori.
} 
we link our sample with the address notification data ${ }^{6}$ to track fathers' locational information pre- and post-child birth.

The sample period covers the years between 2003 and $2019 .{ }^{7}$ In our analysis, we restrict the sample to live-born singleton first child births by excluding observations pertaining to fathers who had twins (or multiple births) or fathers whose first child was stillborn or if the child's gender is not identified. Furthermore, we allow the fathers' data to be observed for a minimum of two consecutive years before the child was born and up to ten years post-child birth. Following this criteria, we focus on fathers whose first child was born between January 2005 and June 2009 (court charges data are available until June 2019). In our final sample, we observe 8085 individuals who became a father at the age of 21 or younger, of whom 4404 individuals are NZ Europeans and 3681 are solely of Māori descent. The sample represents $11 \%$ of all new fathers during the aforementioned five-year period.

\section{Descriptive statistics}

\subsection{Crime and fatherhood in New Zealand}

Figure 1 shows the monthly share of individuals with a conviction in the age range 16 to 44 by Māori and NZ European ethnicity. The figure illustrates that convictions peak at the age of 18 for both the groups and decrease gradually afterwards. We find similar pattern for serious sentences as well.

The graphs in Figure 1 clearly illustrates that criminal activity is concentrated among younger individuals. The differences in conviction rates across the two ethnic groups are particularly interesting. To be specific, at any point in the life cycle, Māori men are about three times more likely to have convictions than NZ Europeans.

Figure 2 relates the age of a father to the first child birth for both the ethnic groups. The visual plot suggests that the two groups behave quite differently in terms of onset of fatherhood. To explain, we find that by the age of 21 , while only $6.9 \%$ of all NZ Europeans have fathered their first child, the equivalent figure stands at $37 \%$ for Māori males.

\footnotetext{
${ }^{6}$ The address notification data is the best-guess list of a person's residential address, which is constructed based on the information received from the most likely public agencies with whom a New Zealander has to be usually registered (e.g. Inland Revenue, Ministry of Social Development, Ministry of Health, Census, etc.).

${ }^{7}$ The Sentencing Act 2002 let to a "a number of substantive and procedural changes to sentencing policy and procedure" (Roberts 2003, p. 254), including the type of sentence for juvenile offenders.
} 
Figure 1: Monthly share of individuals with a conviction (January 2005 - June 2009)

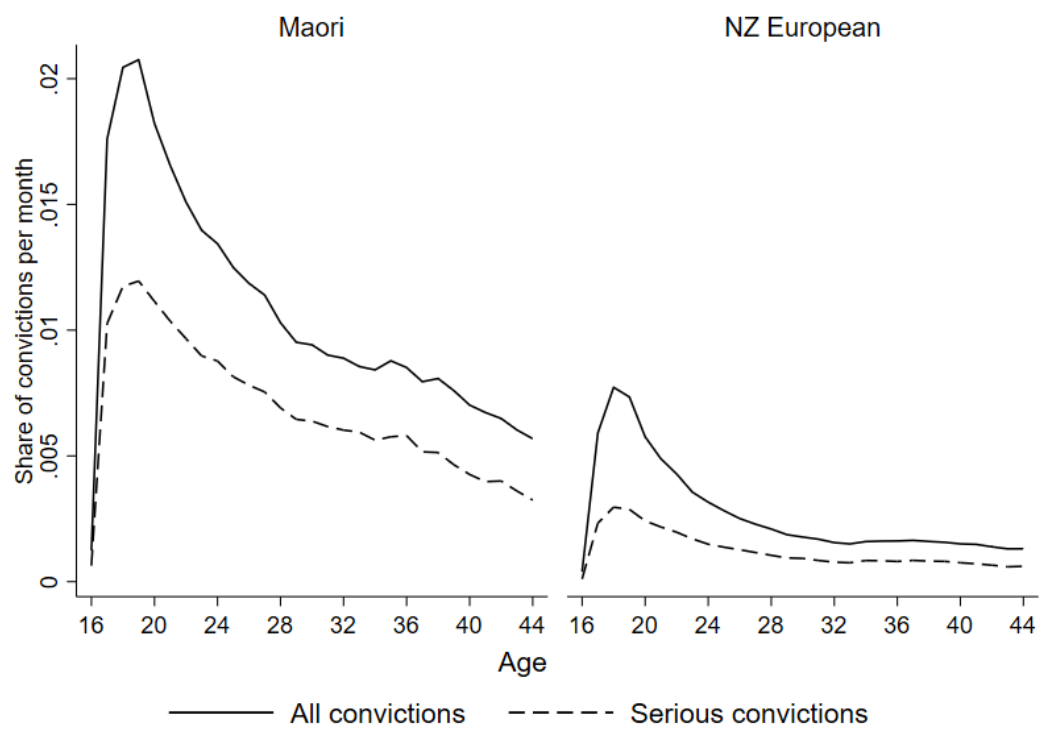

Notes: The graph shows for all Māori (left panel) and NZ European (right panel) men between 16 and 44 the number of convictions and serious convictions per month divided by population in that age bracket.

Figure 2: Age when first child was born (January 2005 - June 2009)

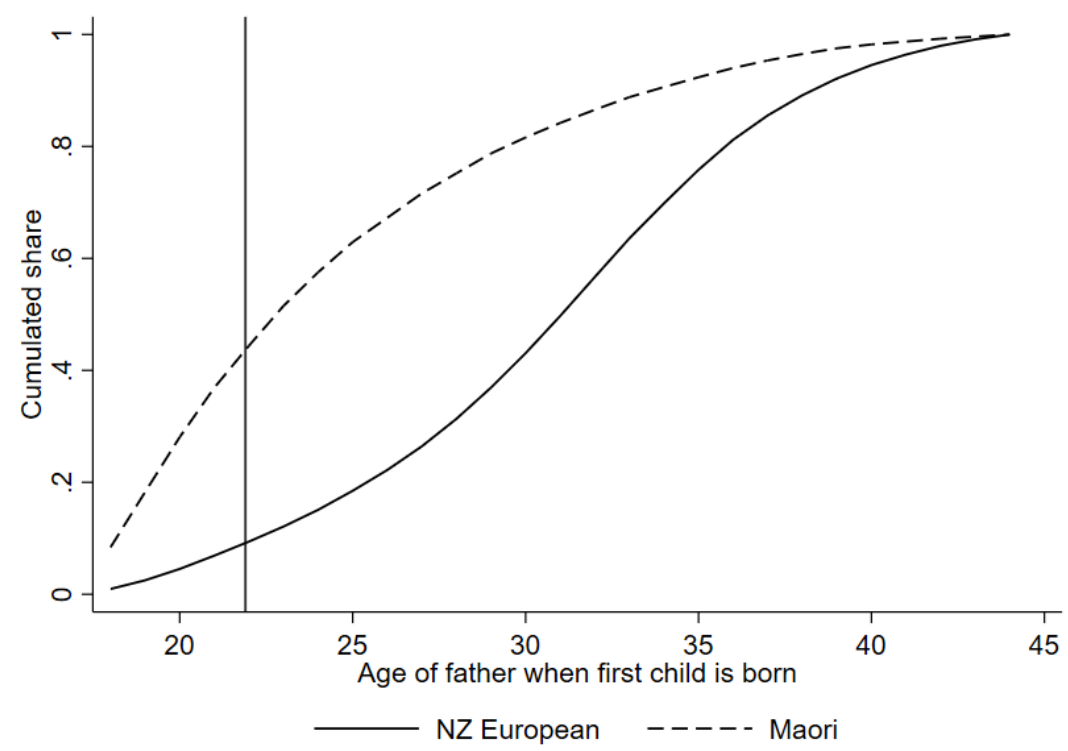

Notes: The graph shows the age for all NZ European and Māori men between 18 and 44 when their first child was born. The vertical line corresponds to the month before turning 22 . 


\subsection{The sample}

To explore the relevance of ethnicity in explaining criminal behaviour, we exploit the randomness of the gender of a child to study its impact on paternal crime after birth. Table 1 presents summary statistics of our main sample for periods prior to child birth (column (1)). The descriptive information is based on the sample of all individuals pooled together from both the ethnic groups, as is commonly done in the literature that relies on empirical evidence drawn from pooled regressions. Panel A depicts baseline characteristics, whereas Panel B provides information on criminal activity measured during the year before birth. To put these numbers into perspective, column (3) presents the same information using all first-time fathers of the full population, aged from 18 to 44 . Our sample of young fathers are different in many aspects. Compared to the full population, our sample is characterized by younger individuals with lower marriage rates and lower average wages. Young fathers also spend more time receiving benefits and fewer months in employment the year before their first child birth. In line with our expectation, individuals in our sample have higher conviction rates compared to the full population of all first-time fathers. Overall, this comparison provides supportive evidence that our sample of young fathers belong to economically disadvantaged groups.

Table 2 provides summary statistics stratified by the two ethnic groups of NZ Europeans and Māori. Columns (5) and (6) show the ethnicity-specific information using all first-time fathers drawn from the full population. The differences between our sample and the full population observed in Table 1 also holds within each respective ethnic group as well (column (1) vs column (5), and column (3) vs column (6)). The table further documents interesting differences between NZ European and Māori men. Compared to the full population of NZ Europeans, the full population of Māori fathers have poorer labor market outcomes in terms of employment spells and earnings. Moreover, the proportion of married Māori males in the full population group is $32 \%$ points lower than the comparable NZ European group. Ethnic differences in criminal records for the overall population groups also appear to be quite pronounced. While among NZ European fathers, about $4 \%$ have any type of conviction before birth, with a share of $21 \%$, the prevalence of having any type of conviction is five times more likely among Māori fathers. The large gap between the two groups is also observed for serious convictions. Referring to our main sample, interestingly, the share of individuals with serious convictions conditional on having any conviction is $12 \%$ among NZ Europeans. Compared to the full population, the difference amounts to $10 \%$ points. For Māori, this difference is much smaller (only 4\%). Within each group, the difference in conviction rates 
Table 1: Summary statistics prior to child birth (pooled sample)

\begin{tabular}{|c|c|c|c|}
\hline & \multicolumn{2}{|c|}{ Main sample } & \multirow{2}{*}{$\begin{array}{c}\text { Population }^{\dagger} \\
\text { mean } \\
(3)\end{array}$} \\
\hline & $\begin{array}{c}\text { mean } \\
(1)\end{array}$ & $\begin{array}{c}p \text {-value } \\
\text { boy vs. girl } \\
(2)\end{array}$ & \\
\hline \multicolumn{4}{|c|}{ Panel A: baseline characteristics } \\
\hline Age & $\begin{array}{l}19.69 \\
(1.08)\end{array}$ & 0.629 & $\begin{array}{l}30.34 \\
(6.28)\end{array}$ \\
\hline Income & $\begin{array}{c}9.44 \\
(1.24)\end{array}$ & 0.657 & $\begin{array}{l}10.45 \\
(1.14)\end{array}$ \\
\hline Months employed & $\begin{array}{c}8.61 \\
(3.69)\end{array}$ & 0.633 & $\begin{array}{c}10.04 \\
(3.24)\end{array}$ \\
\hline Months benefits & $\begin{array}{c}1.61 \\
(3.24)\end{array}$ & 0.459 & $\begin{array}{c}0.60 \\
(2.20)\end{array}$ \\
\hline Married & $\begin{array}{c}0.03 \\
(0.03)\end{array}$ & 0.743 & $\begin{array}{c}0.38 \\
(0.24)\end{array}$ \\
\hline \multicolumn{4}{|c|}{ Panel B: convictions } \\
\hline Convictions & $\begin{array}{c}0.26 \\
(0.46)\end{array}$ & 0.921 & $\begin{array}{c}0.06 \\
(0.24)\end{array}$ \\
\hline Serious convictions & $\begin{array}{c}0.14 \\
(0.36)\end{array}$ & 0.673 & $\begin{array}{c}0.03 \\
(0.18)\end{array}$ \\
\hline
\end{tabular}

Notes: The table shows means and in parentheses standard deviations for the pooled sample of NZ Europeans and Māori. Age and marriage status refer to the time of birth of the child. Wage is measured as the log of the average monthly wage one year before birth. Employment and benefits are measured as the average number of months in the respective state the year before birth. Crime information refer to the share of individuals with convictions during the year before birth. ${ }^{\dagger}$ Accounts for all NZ European and Māori men who had their first child born between the age of 18 and 44. Statistics refer to first child.

is less pronounced for fathers of Māori descent, indicating higher overall conviction rates. The presumption that young fathers are more likely to have disadvantaged backgrounds also holds for each ethnic group, when our main sample is compared to the larger population of first-time fathers.

Panel A of Table 3 shows the distribution of convictions by age for fathers without a child, and our sample of young first-time fathers. We observe that conviction rates are substantially higher among young fathers, which holds for both NZ Europeans and Māori. The share of serious sentences conditional on having a conviction (Panel B) is, however, less pronounced among Māori, where the difference between individuals with and without a child is $4-5 \%$ points. Among NZ European, this difference is $14-18 \%$ points.

Important for our setup is that the gender of the child is unrelated to pre-birth observable characteristics of the father. Appendix Table A.1 shows that none of the observable characteristics including father's ethnicity, father's age at child birth, or birth year and month are related to first born child's gender. This suggests that selective abortion is unlikely to drive our results, which in any case should not be possible in New Zealand given that abortions are illegal once the gender of the 
Table 2: Summary statistics prior to child birth (by ethnicity)

\begin{tabular}{|c|c|c|c|c|c|c|}
\hline & \multicolumn{4}{|c|}{ Main sample } & \multicolumn{2}{|c|}{ Population $^{\dagger}$} \\
\hline & \multicolumn{2}{|c|}{ NZ European } & \multicolumn{2}{|c|}{ Māori } & \multirow{2}{*}{ 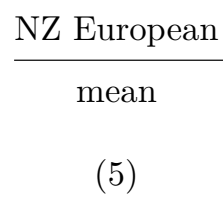 } & \multirow{2}{*}{$\begin{array}{c}\text { Māori } \\
\text { mean } \\
(6)\end{array}$} \\
\hline & $\begin{array}{l}\text { mean } \\
(1)\end{array}$ & $\begin{array}{l}p \text {-value } \\
\text { boy vs. girl } \\
(2)\end{array}$ & $\begin{array}{c}\text { mean } \\
(3)\end{array}$ & $\begin{array}{l}p \text {-value } \\
\text { boy vs. girl } \\
(4)\end{array}$ & & \\
\hline \multicolumn{7}{|c|}{ Panel A: baseline characteristics } \\
\hline Age & $\begin{array}{l}19.84 \\
(1.05)\end{array}$ & 0.989 & $\begin{array}{c}19.52 \\
(1.09)\end{array}$ & 0.364 & $\begin{array}{l}31.18 \\
(5.89)\end{array}$ & $\begin{array}{l}24.96 \\
(5.99)\end{array}$ \\
\hline Income & $\begin{array}{c}9.67 \\
(1.12)\end{array}$ & 0.791 & $\begin{array}{c}9.14 \\
(1.33)\end{array}$ & 0.539 & $\begin{array}{l}10.58 \\
(1.04)\end{array}$ & $\begin{array}{c}9.61 \\
(1.34)\end{array}$ \\
\hline Months employed & $\begin{array}{c}9.41 \\
(3.39)\end{array}$ & 0.488 & $\begin{array}{c}7.55 \\
(3.80)\end{array}$ & 0.282 & $\begin{array}{l}10.33 \\
(3.09)\end{array}$ & $\begin{array}{c}8.61 \\
(3.77)\end{array}$ \\
\hline Months benefits & $\begin{array}{c}1.30 \\
(2.96)\end{array}$ & 0.276 & $\begin{array}{c}1.99 \\
(3.50)\end{array}$ & 0.897 & $\begin{array}{c}0.38 \\
(1.78)\end{array}$ & $\begin{array}{c}1.98 \\
(3.65)\end{array}$ \\
\hline Married & $\begin{array}{c}0.05 \\
(0.05)\end{array}$ & 0.881 & $\begin{array}{c}0.01 \\
(0.01)\end{array}$ & 0.804 & $\begin{array}{c}0.43 \\
(0.25)\end{array}$ & $\begin{array}{c}0.09 \\
(0.08)\end{array}$ \\
\hline \multicolumn{7}{|c|}{ Panel B: convictions } \\
\hline Convictions & $\begin{array}{c}0.22 \\
(0.43)\end{array}$ & 0.715 & $\begin{array}{c}0.30 \\
(0.48)\end{array}$ & 0.749 & $\begin{array}{c}0.04 \\
(0.19)\end{array}$ & $\begin{array}{c}0.21 \\
(0.42)\end{array}$ \\
\hline Serious convictions & $\begin{array}{c}0.12 \\
(0.34)\end{array}$ & 0.696 & $\begin{array}{c}0.17 \\
(0.39)\end{array}$ & 0.301 & $\begin{array}{c}0.02 \\
(0.14)\end{array}$ & $\begin{array}{c}0.13 \\
(0.34)\end{array}$ \\
\hline
\end{tabular}

Notes: The table shows means and in parentheses standard deviations differentiating between NZ Europeans and Māori. Age and marriage status refer to the time of birth of the child. Wage information is measured as the log average monthly wage one year before birth. Employment and benefits are measured as the average number of months in the respective state one year before birth. Crime information refer to the share of individuals with convictions during the year before birth. ${ }^{\dagger}$ Accounts for all NZ European and Māori men who had their first child between the age of 18 and 44 . All statistics refer to the first-born child.

child is revealed (as long as the pregnancy does not bear substantial health risks). Columns (2) and (4) of Table 2 provide further $p$-values of simple $t$-tests between individuals who fathered a boy versus those who had a girl. Our sample appears to be well balanced with respect to the gender of the child, as none of the differences are significant.

\subsection{Conviction rates around birth}

Figure 3 provides descriptive differences in conviction rates for first-time fathers with a son compared to those with a daughter, before and after birth and that too by ethnicity. The upper panel (Panel A-1 and Panel B-1) of Figure 3 documents differences in the total accumulated convictions (red triangles) and conviction probabilities (blue $\mathrm{x}$ ) around birth of the child for all young fathers in our sample. On a descriptive basis, the difference in convictions for NZ Europeans is around 0.05 $\log$ points lower in post-birth years, indicating that young males who father a boy have a $5 \%$ points fewer convictions than those that father a daughter. There is a 
Table 3: Convictions and early fatherhood

\begin{tabular}{|c|c|c|c|c|c|c|}
\hline \multirow[t]{2}{*}{ Age } & \multicolumn{3}{|c|}{ NZ European } & \multicolumn{3}{|c|}{ Māori } \\
\hline & $\begin{array}{l}\text { No child } \\
\text { (1) }\end{array}$ & $\begin{array}{l}\text { child } \\
(2)\end{array}$ & p-value & $\begin{array}{l}\text { No child } \\
\text { (3) }\end{array}$ & $\begin{array}{l}\text { child } \\
(4)\end{array}$ & p-value \\
\hline \multicolumn{7}{|c|}{ Panel A: Distribution of convictions } \\
\hline 18 & 0.0070 & 0.0456 & 0.000 & 0.0162 & 0.0572 & 0.000 \\
\hline 19 & 0.0064 & 0.0394 & 0.000 & 0.0155 & 0.0555 & 0.000 \\
\hline 20 & 0.0049 & 0.0292 & 0.000 & 0.0127 & 0.0490 & 0.000 \\
\hline 21 & 0.0041 & 0.0241 & 0.000 & 0.0113 & 0.0430 & 0.000 \\
\hline \multicolumn{7}{|c|}{ Panel B: Share of serious sentences } \\
\hline 18 & 0.3657 & 0.4975 & 0.000 & 0.5590 & 0.5941 & 0.004 \\
\hline 19 & 0.3686 & 0.5062 & 0.000 & 0.5561 & 0.5983 & 0.000 \\
\hline 20 & 0.3865 & 0.5590 & 0.000 & 0.5859 & 0.6378 & 0.000 \\
\hline 21 & 0.4083 & 0.5813 & 0.000 & 0.6053 & 0.6438 & 0.003 \\
\hline
\end{tabular}

Notes: The table shows monthly conviction rates for young fathers between 18 and 21 years with and without a child. Panel A depicts the share of individuals with any convictions. Panel B shows the share of serious sentences conditional on having any conviction.

$3 \%$-points decline in the probability of having convictions over two years after birth and the likelihood is precisely zero at the end of the observation window. For the sample of Māori young fathers, we do not observe any differential behavior. ${ }^{8}$

The lower panel (Panel A-2 and Panel B-2) of Figure 3 show that the overall effect for NZ Europeans is likely driven by serious convictions. Three noteworthy inferences can be derived from this panel. First, accumulated serious convictions prior to birth are similar for young males who father a girl vs. those with a boy. This holds regardless of individuals' ethnicity. Second, among NZ Europeans, the accumulated numbers of serious convictions are persistently lower for young males whose first-born is a boy than those with a girl. This difference is continuously increasing and amounts to $8 \mathrm{log}$ points at $10^{\text {th }}$ year after birth. At the extensive margin, we find a persistent decrease in the probability of serious conviction by about $3 \%$ points. Third, for young Māori fathers, we do not see any discernible differences in serious convictions between the two child genders.

Appendix Table A.2 provides information on all conviction rates, including serious and non-serious sentence types. In terms of serious convictions, NZ Europeans who father a boy have on average 3.6 convictions ten years after birth, whereas those who father a girl have on average 4.1 convictions. In comparison regardless of the gender of their first child, Māori fathers have, on average, 7.0 serious convictions

\footnotetext{
${ }^{8}$ The figure further shows as a placebo test conviction rates two years up to six months before birth. We choose six month before birth because women usually take an ultrasound test during pregnancy that typically can reveal the sex of the baby very accurately by the $12^{\text {th }}-14^{\text {th }}$ week of pregnancy (Dahl and Moretti 2008). Descriptively, we do not observe differential effects with respect to the child's gender for either ethnic group prior to birth.
} 
accumulated over ten years after birth.

Figure 3: Child-gender related difference in conviction rates
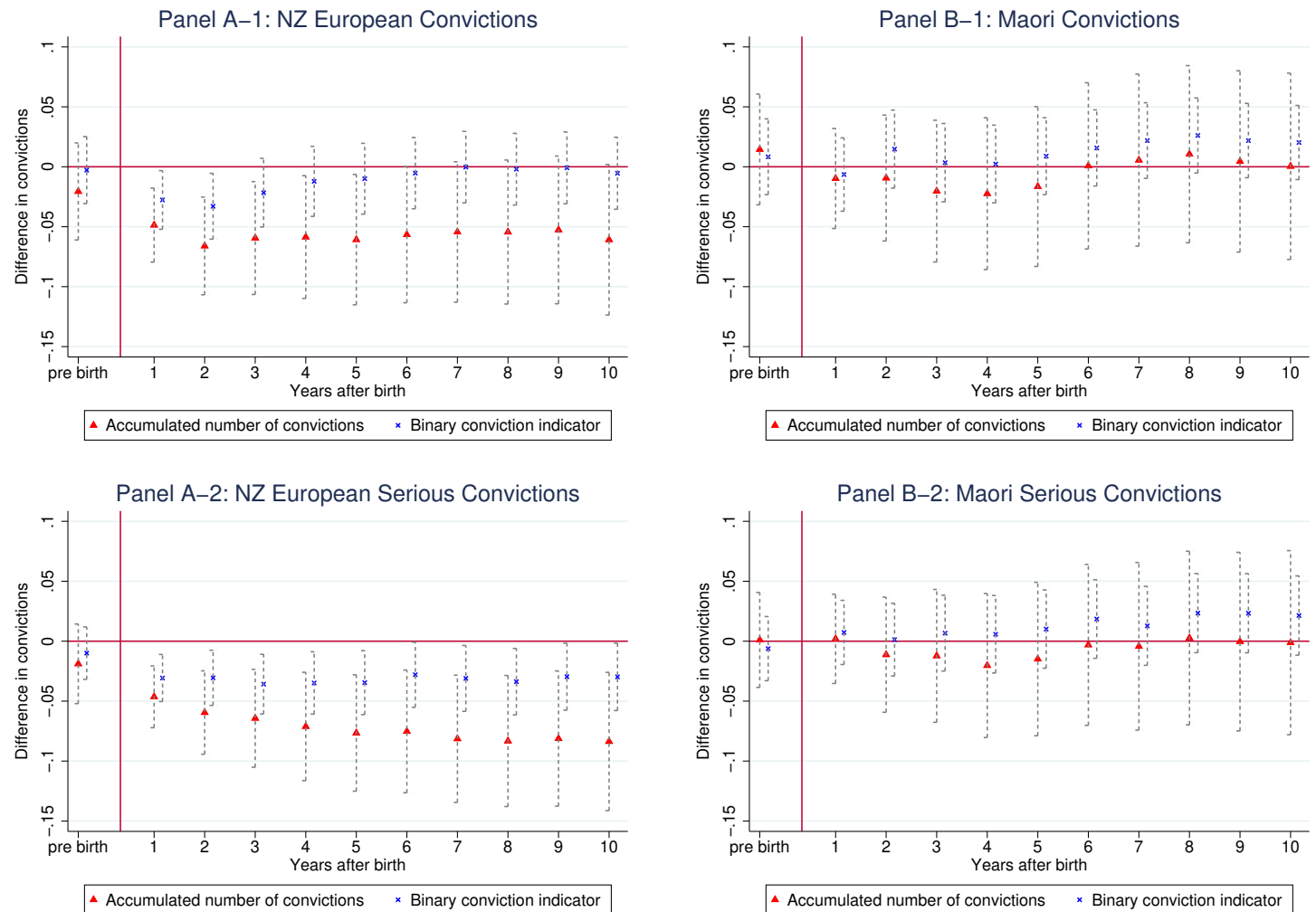

Notes: The graph shows the gender related difference (boy vs. girl) based on standard $t$-tests of the log of the accumulated number of convictions (red triangle) and a binary indicator of having received at least one conviction (blue X) before and after child birth. Each dot corresponds to a separate $t$-test. Panels A-1 and A-2 refer to NZ Europeans. Panels B-1 and B-2 refer to Māori. The pre-birth period refers to the time period from two years to six months prior to birth. At six months before birth the gender of the child can first be identified. Dotted lines around each point estimate correspond to the $95 \%$ confidence interval. Number of observations: 4404 NZ Europeans and 3681 Māori.

\section{Empirical strategy}

In our empirical analysis, we compare conviction-based outcomes among individuals who father a boy relative to those with a girl. Our outcome variable, $y_{i t}$, is measured either in terms of the accumulated number of convictions an individual $i$ receives after the birth of his first-born up to year $t$ or a dichotomous indicator of whether individual $i$ has committed any convicted offence after his first child birth up to $t$.

To estimate the effect of child gender on criminal activities, our model takes the following form:

$$
y_{i t}^{r}=\alpha+\beta \cdot \operatorname{Son}_{i}+X_{i}^{\prime} \gamma+u_{i t},
$$


where $\operatorname{son}_{i}$ is an indicator equal to 1 if the child is a boy, and zero otherwise. The coefficient of interest, $\beta$, measures the causal effect of the gender of the child on crime. As outlined before, we (i) count the number of convictions from birth and (ii) estimate probability models of having convictions $t$ years after birth. We follow each individual for ten years post-child birth. As for the accumulated number of convictions, we log the outcome variable up to time $t$ and add a value of 1 . In this case, our outcome variable is:

$$
y_{i t}^{r}=\log \left(\sum_{0}^{t} \text { convictions }_{i t}+1\right) \text {, }
$$

with $t \in\{0, \ldots, 10\}$. As described above, our observation period for the pre-birth period ranges from 24 months to six months prior birth and are used as a placebo exercise. When estimating the probability of having convictions $t$ years after birth, we transform Equation (2) as $y_{i t}^{r}=\mathbb{1}\left\{y_{i t}^{r}>1\right\}$. Superscript $r$ refers to the overall number of convictions, and serious and non-serious convictions.

The vector $X_{i}$ includes time-invariant information, including year and month of birth of the child, age of the father at child birth, log number of convictions in the pre-birth period and an indicator variable on being imprisoned in the prebirth period. Despite the exogenous nature of the child's gender, we include these pre-birth observable characteristics to increase the precision of our estimates. To this end, we also restrict the sample to two post-birth conditions, such that: (i) individual $i$ is not deceased at time $t$ and (ii) the individual has not spent more than $80 \%$ of the time since child birth up to year $t$ overseas. ${ }^{9}$

\section{Results}

\subsection{Baseline results}

Figure 4 provides point estimates of the impact of first-born's gender (indicator equals 1 if the child is a boy, 0 otherwise) on the total number of accumulated convictions before and after birth and the number of accumulated serious convictions using a pooled sample of NZ Europeans and Māori fathers. In this specification, we include a dummy variable equal to 1 if the individual is of Māori descent and 0 if the father is NZ European.

\footnotetext{
${ }^{9} 10$ years after the birth of the first child, 114 men were reported to be deceased in the DIA's death registers. Moreover, 198 men appeared to have spent at least $80 \%$ of the time since birth up to 10 years outside New Zealand. However, the results are not sensitive to the threshold and are robust for any proportion of time spent overseas.
} 
Figure 4: Child-gender related difference in conviction rates

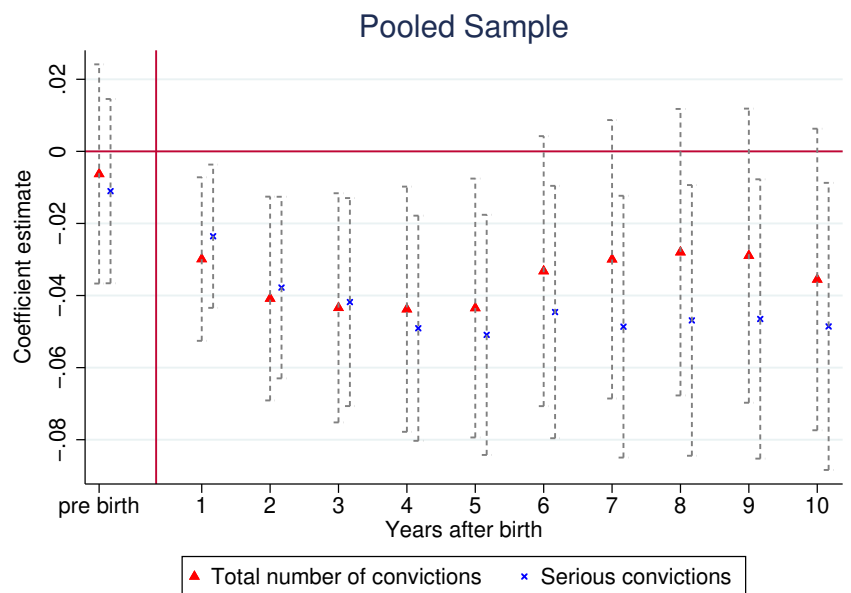

Notes: The graph shows the child-gender related difference (boy vs. girl) based on OLS regressions with robust standard errors of the log accumulated number of convictions (red triangle) and the log accumulated number of serious convictions (blue X) before and after birth. Each dot corresponds to a separate regression. The pre-birth period refers to the time period between two year to six months prior birth, at which time the gender of the child can first be identified. Dotted lines around each point estimate correspond to the $95 \%$ confidence interval. Number of observations: 8085 .

In line with Dustmann and Landers $\varnothing$ (2018), we find a statistically significant decrease in the number of total convictions by about $5 \%$ points for at least four years after birth if the first-born child is a boy. This effect is driven by serious convictions, for which the negative effect remains persistently significant throughout the ten-year period after birth. However, when splitting the sample by ethnicity, we find very different results for the two ethnic groups. While the raw descriptive differences were visually plotted in Figure 3, in Figure 5 we provide point estimates (along with 95\% confidence intervals) of the effect of first-born child's gender on convictions rates before and after birth. In line with the above results, total accumulated convictions drop persistently by $5 \%$ points for ten years after birth in case NZ European males have a son relative to having a daughter. This again is driven by serious convictions with the point estimate consistently hovering around $-8 \%$ points for ten years after birth. In contrast, the point estimates for Māori are not statistically significant and linger close to zero.

At the extensive margin, Table A.4 in the Appendix provides point estimates for the pooled sample regression results using as the outcome variable the binary indicator of having received any convictions or any serious convictions. This extensive margin estimate provides evidence for no effect of the gender of the child. This indicates that young fathers are becoming less criminal in terms of convictions but are not observed to stay out of the criminal justice system. In the Appendix, Table A.5 shows the results using the binary indicator differentiated by ethnicity. 
For NZ Europeans, at the extensive margin there is decrease in the probability of receiving any serious convictions by $2.4 \%$ points ten years after child birth. Importantly, pre-birth crime is not affected by the gender of the child, providing credibility for the exogeneity of our key explanatory variable.

Figure 5: Child-gender related difference in conviction rates by ethnicity
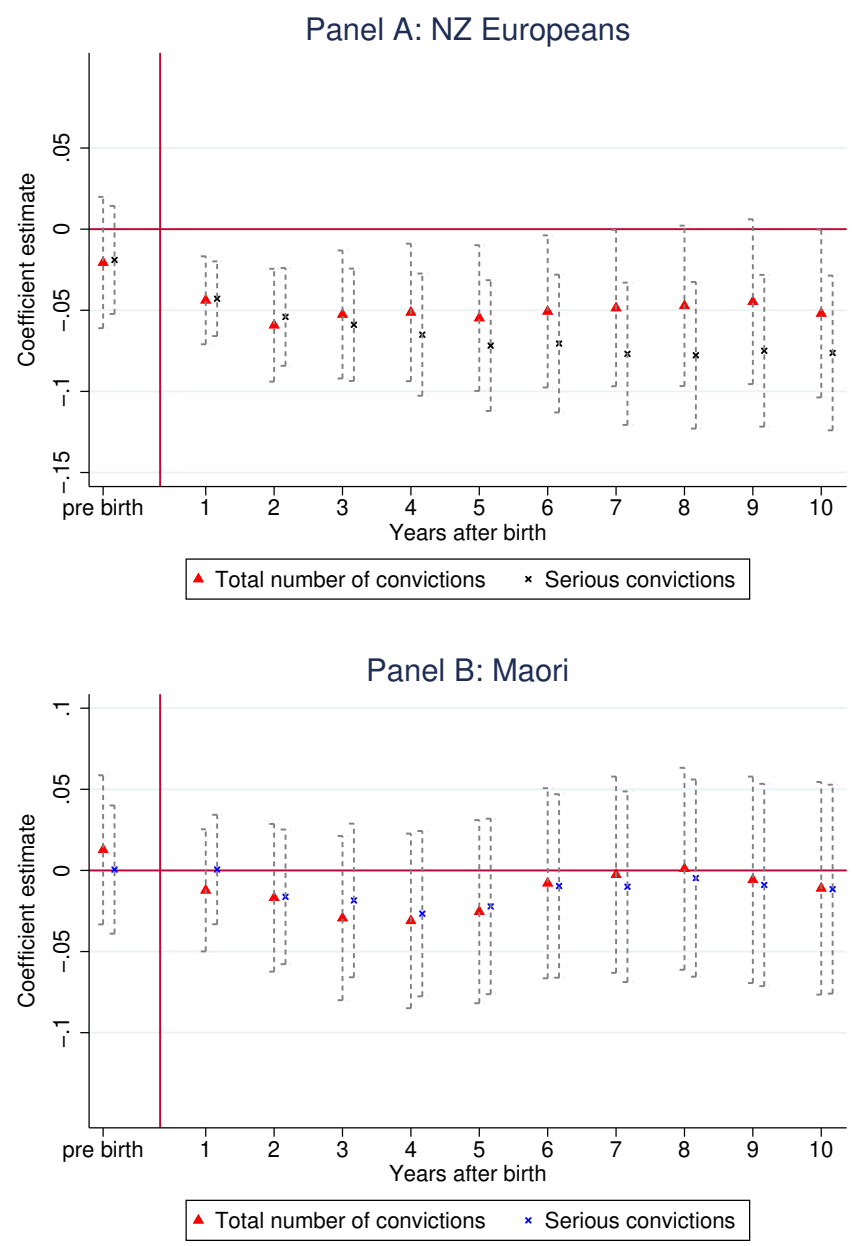

Notes: The graph shows the child-gender related difference (boy vs. girl) based on OLS regressions with robust standard errors of the log accumulated number of convictions (red triangle) and the log accumulated number of serious convictions (blue X) before and after child birth. Each dot corresponds to a separate regression. Panel A provides the results for NZ Europeans. Panel B provides the results for Māori. The pre-birth period refers to the time period between two year up to six months prior birth, which is when the gender of the child can first be identified. Dotted lines around each point estimate correspond to the $95 \%$ confidence interval. Number of observations: 4404 NZ Europeans and 3681 Māori.

The results so far point towards the importance of heterogeneous effects across ethnic groups. Māori do not seem to adjust their criminal behavior after child birth as a response to their first child's gender, whereas young European males who father a boy reduce their criminal behavior at the intensive and extensive margin relative 
to individuals who father a girl. The empirical results provide substantive insights into the perception that major life events which often represent key 'turning points' in a person's life can trigger different behavioral responses across ethnic groups.

\section{$5.2 \quad$ Stratifying by severity}

Next we stratify our sample by type of criminal convictions before birth of the firstborn child. For this, we define three groups for our period between 24 months and 6 months prior to child birth: the first consists of individuals with any criminal records, the second group includes those with serious sentences only, and the last category incorporates people with no prior convictions. As we had shown in Table 2 above, the overall pre-birth level of convictions for young fathers is high, with the share being $22 \%$ for NZ Europeans and 38\% for Māoris. The results for the first group are presented in Panels A-1 and B-1 of Figure $6 .^{10}$ The left hand side column of Figure 6 shows the results for the NZ Europeans, and the right hand side for Māori. Each panel then shows two results, one for all convictions, and one for the sub-category of serious convictions. In the first Panel we document a significant drop in criminal convictions for NZ Europeans if the first born was a boy (vs. a girl), while for Māori it declines slightly but remains insignificant. For NZ Europeans ten years after birth, the differential effect amounts to about $13 \%$ points.

Having said that, the differential effect between NZ Europeans and Māori is particularly strong for those with serious pre-birth convictions. For this group of individuals, the differential effect is about $25 \%$ points, with the improvements being entirely confined to the NZ Europeans. For Māori fathers, point estimates are around $-5 \%$ points but statistically insignificant. Finally, Panels A-3 and B-3 of Figure 6 provide the results for those with no prior criminal record. Again, we document ethnic differences. Focusing on Māoris, we observe an alternating - albeit insignificant - coefficient around zero, while for NZ Europeans, we continue to see a decline that is only significant for the serious convictions category.

Appendix Tables A.6 to A.9 provide estimates of the impact of son vs. daughter on the likelihood of fathers having criminal conviction. The effects for Māori are again insignificant with the point estimates being close to zero.

\footnotetext{
${ }^{10}$ We again show for each group the accumulated number of total convictions, as well as serious convictions and refer to the Appendix for the effects of gender-related conviction probabilities (extensive margin). Table A.3 provides information on actual conviction rates for individuals with different pre-birth criminal records. Conditional on having at least one conviction prior to birth, NZ Europeans with a daughter have on average 3.9 convictions 10 years after birth, whereas young fathers with a boy have on average 3.2 overall convictions. In comparison, Māori have accumulated around 7 convictions 10 years after birth.
} 
Figure 6: Child-gender related difference in conviction rates by ethnicity and prebirth criminal record
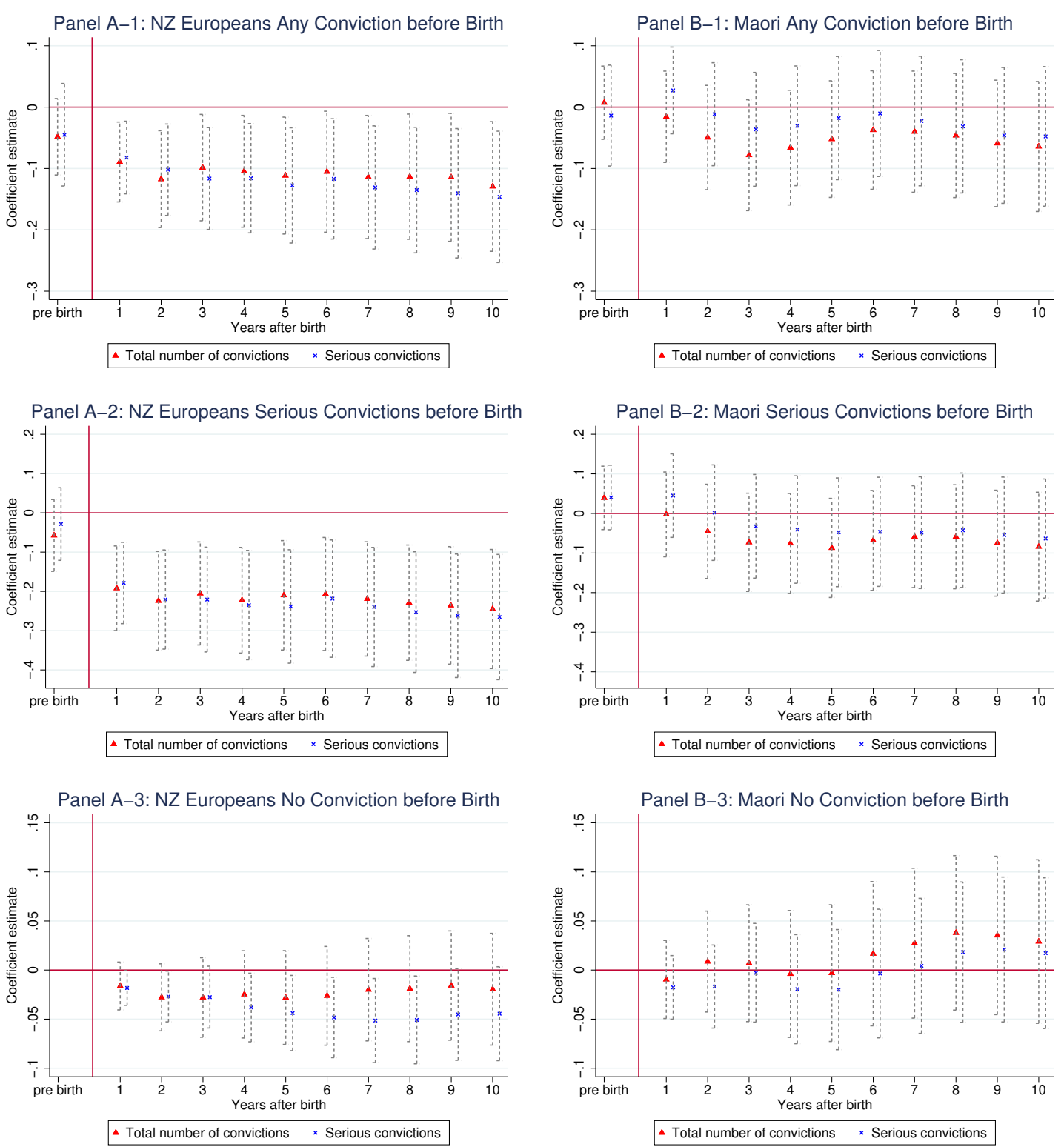

Notes: The graph shows the gender related difference (boy vs. girl) based on OLS regressions with robust standard errors of the log of the accumulated number of convictions (red triangle) and the log accumulated number of serious convictions (blue X) before and after child birth. Each dot corresponds to a separate regression. Panel A provides the results for NZ Europeans. Panel B provides the results for Māori. The pre-birth period refers to the time period between two year up to six months prior birth, which is the time when the gender of the child can first be identified. Dotted lines around each point estimate correspond to the $95 \%$ confidence interval. Number of observations: Panel A-1: 1473; Panel A-2: 717; Panel A-3: 2931; Panel B-1: 1443; Panel B-2: 807; Panel B-3: 2 238; .

In terms of extensive margin, NZ Europeans with a serious conviction before birth experience a decrease in the probability of having a serious conviction by almost $9 \%$ points over the ten years after birth. ${ }^{11}$

${ }^{11}$ In a separate specification, we additionally control for the criminal record of the mother of 


\subsection{Regional deprivation}

Our results so far provide evidence that young NZ European fathers reduce their criminal activity if the first child is a boy. This holds true in particular for individuals with serious criminal records before birth. To explore potential mechanisms underlying our key findings, an important heterogeneity to consider is the quality of the fathers' neighbourhood. Living in deprived neighbourhoods has negative implications on physical and subjective well-being, (Katz et al. 2001; Kling et al. 2007; Ludwig et al. 2012), criminal behaviour (Kling et al. 2005; Dustmann and Landers $\varnothing$ 2018), and labor market prospects (Chetty et al. 2016; Chetty and Hendren 2018).

In order to identify implications of neighbourhood quality, we link each individual to the geo-spatial information of the IDI's address notification data that further allows us to identify the socio-economic deprivation levels associated with the father's residential location. Stats NZ provides an identifier on the smallest geographic unit available, the so-called 'meshblock' which covered a median of about 81 individuals in 2013. Since 1991, information provided by the census ${ }^{12}$ is used to measure the socio-economic deprivation for each meshblock (Atkinson et al. 2014). It uses a range of variables and calculates for each meshblock a deprivation index with a mean of 1000 index points and a standard deviation of $100{ }^{13}$ Next, the continuous index-based measure is classified into deciles to generate an ordinal scale ranging from 1 to 10 with a higher score indicating a higher deprivation level. We make use of the address notification dataset within the IDI, which uses prioritised individuals' address history to identify the most accurate meshblock information.

Table 4 shows that Māori groups tend to reside in areas with a higher deprivation level, and this is independent of having any conviction before child birth. Importantly, a $t$-test on the equality of means between the first-born child's gender shows no significant differences even for father with any pre-birth serious conviction. This indicates that on average, the neighborhood quality of young fathers whose firstborn child is a boy does not vary with the locational quality of fathers who had a

the first-born child. Intra-household bargaining might lead to substitution of time and potentially criminal activity that might differ depending of the gender of the child. In terms of the number of convictions of the mother, independent of the father's ethnicity, the number of convictions as well as the level of seriousness is below the one of the fathers. Moreover, mothers who have not received any convictions before the birth of their child is with about $90 \%$ the largest group. As an unreported robustness check, we account for the mother's criminal record in the regression models and find that the coefficients of interest are unaltered.

${ }^{12}$ The census is conducted every five years, and in 2011 it was postponed to 2013 due to the 2011 Christchurch earthquake.

${ }^{13}$ The construction of the index-based measures account for several dimensions of deprivation indicated by outcomes including income, employment, qualification, ownership of house, health, safety, etc. 
daughter.

Table 4: Social Deprivation Index

\begin{tabular}{|c|c|c|c|c|}
\hline & \multicolumn{2}{|c|}{ NZ European } & \multicolumn{2}{|c|}{ Māori } \\
\hline & son & daughter & son & daughter \\
\hline Total sample & $\begin{array}{c}6.36 \\
(2.69)\end{array}$ & $\begin{array}{c}6.33 \\
(2.63)\end{array}$ & $\begin{array}{c}8.23 \\
(2.18)\end{array}$ & $\begin{array}{c}8.24 \\
(2.10)\end{array}$ \\
\hline Serious conviction before birth & $\begin{array}{c}6.90 \\
(2.62)\end{array}$ & $\begin{array}{c}6.79 \\
(2.58)\end{array}$ & $\begin{array}{c}8.43 \\
(2.11)\end{array}$ & $\begin{array}{c}8.38 \\
(2.01)\end{array}$ \\
\hline
\end{tabular}

Notes: The table shows mean and in parentheses standard deviation of the 2006 Social Deprivation Index for NZ Europeans and Māori on the meshblock level, differentiated according to the pre-birth conviction level.

Next, we split the sample into men who lived in highly deprived areas when their first child was born (scale of 9 or 10) and those who resided in relatively less deprived areas, and re-run the regression separately. ${ }^{14}$ Table 5 provides the point estimates of the effect of the first-born's gender on serious convictions 10 years after birth for fathers who lived in highly deprived areas. Appendix Table A.10 provides the results for each year after child birth and for fathers who lived in less deprived areas. In Table 5, columns (1) and (4) provide the effect on the accumulated number of serious convictions and in columns (2) and (5) the outcome variable is an indicator equal to 1 if father has any serious conviction following the 10 years post birth.

The results in Table 5 suggest that that Māori males who start off (i.e. pre-birth location) in highly deprived areas do not adjust their criminal activity depending on the gender of the first child. The documented negative point estimates among NZ Europeans in the baseline regression is slightly driven by individuals who live in areas with a high deprivation index (Appendix Table A.10 shows that this finding is stable over time). The effect, however, is also observed for individuals in less deprived areas. For NZ European fathers who lived in highly deprived areas and also had a serious conviction before birth, we find that the effect of a son is relatively stronger. The accumulated number of convictions drops by on average $32 \%$ points (compared to $26 \%$ points documented in Panel A-2 of Figure 6). The probability of having serious convictions drops by $13 \%$ points (column (2)). The size of the point estimates for NZ European men with a serious conviction before birth but who lived in areas with a lower deprivation scores is found to be lower in absolute terms, but remains statistically significant (see Columns (6) and (7) of Table A.10). Māori men who lived in highly deprived areas have point estimates close to zero. This holds true

\footnotetext{
${ }^{14}$ To put the separation into perspective, we use the 2013 Census and link it with the Inland Revenue tax data on wages and salaries for the Census month March 2013. Dividing the meshblocks into deprived and less deprived areas reveals stark differences: the mean earnings are at NZ $\$ 4,427$ for non-deprived areas and NZ\$3,521 for deprived areas.
} 
Table 5: Child-gender related difference in serious conviction rates and deprivation of neighborhood by ethnicity and pre-birth convictions, 10 years after birth and differentiated according to the 2006 Social Deprivation Index

\begin{tabular}{|c|c|c|c|c|c|c|}
\hline & \multicolumn{3}{|c|}{ NZ European } & \multicolumn{3}{|c|}{ Māori } \\
\hline & $\begin{array}{l}\text { \# conviction } \\
\text { (1) }\end{array}$ & $\begin{array}{c}\mathrm{P}(\text { conviction }) \\
(2)\end{array}$ & $\begin{array}{c}\Delta \text { (deprived) } \\
(3)\end{array}$ & $\begin{array}{c}\text { \# conviction } \\
(4)\end{array}$ & $\begin{array}{c}\mathrm{P}(\text { conviction }) \\
(5)\end{array}$ & $\begin{array}{c}\Delta(\text { deprived }) \\
(6)\end{array}$ \\
\hline \multicolumn{7}{|c|}{$\begin{array}{l}\text { Highly deprived areas (deprivation score: } 9 \text { or 10) } \\
\text { Full sample }\end{array}$} \\
\hline Son & $\begin{array}{c}-0.112^{* *} \\
(0.053)\end{array}$ & $\begin{array}{l}-0.041 \\
(0.025)\end{array}$ & $\begin{array}{c}-0.073^{* *} \\
(0.029)\end{array}$ & $\begin{array}{l}-0.031 \\
(0.042)\end{array}$ & $\begin{array}{l}-0.004 \\
(0.020)\end{array}$ & $\begin{array}{l}-0.014 \\
(0.021)\end{array}$ \\
\hline$N$ & 1122 & 1122 & 080 & & 2184 & 079 \\
\hline \multicolumn{7}{|c|}{ Serious conviction before birth } \\
\hline Son & $\begin{array}{c}-0.316^{* *} \\
(0.150)\end{array}$ & $\begin{array}{c}-0.130^{* * *} \\
(0.050)\end{array}$ & $\begin{array}{l}-0.067 \\
(0.069)\end{array}$ & $\begin{array}{c}0.041 \\
(0.094)\end{array}$ & $\begin{array}{c}0.008 \\
(0.026)\end{array}$ & $\begin{array}{l}-0.023 \\
(0.043)\end{array}$ \\
\hline$N$ & 228 & 228 & 228 & 510 & 510 & 486 \\
\hline \multicolumn{7}{|c|}{$\begin{array}{l}\text { Notes: The table shows the gender related difference (boy vs. girl) based on OLS regressions differentiated by the } \\
\text { Social Deprivation Index. Individuals are assigned into high/low deprived areas at the time of child birth. The } \\
\text { first two columns within each ethnic group provide results of serious convictions } 10 \text { years after birth. Columns } \\
\text { (3) and (6) provides the result of a change in the local deprivation index of the neighborhood } 10 \text { years after child } \\
\text { birth. Each coefficient corresponds to a separate regression. \# conviction refers to the log-transformed accumulated } \\
\text { number of convictions. P(conviction) refers to an indicator variable taking the value of } 1 \text { if number of convictions } \\
\text { are above zero and } 0 \text { otherwise. } \Delta \text { (deprived) refers to an indicator variable taking the value of } 1 \text { if neighborhood } \\
\text { has a deprivation score of } 9 \text { or } 10 \text { and } 0 \text { otherwise. Columns }(1) \text { to }(3) \text { correspond to all NZ Europeans and those } \\
\text { with at least one serious pre-birth conviction. Columns }(4) \text { to }(6) \text { correspond to all Māori and those with at least } \\
\text { one serious pre-birth conviction. Robust standard errors in parentheses, significance level: } * * * \text { p }<0.01, * * \text { p }<0.05, \\
* \text { p }<0.1 \text {. }\end{array}$} \\
\hline
\end{tabular}

for the full sample as well as for young fathers with a serious conviction before birth. One exception are the young Māori fathers with a serious conviction before birth in less deprived areas who have a point estimate comparable to their equivalent NZ European counterparts for few years starting from the third post-birth year onward (column (7) of Table A.10). However, at the extensive margin, the probability of have accumulated serious convictions is close to zero.

Columns (3) and (6) of Table 5 provide evidence on the spatial mobility of the father into better neighbourhoods between the time of birth and 10 years postbirth. Young NZ Europeans who lived in highly deprived areas are less likely to stay in such areas if the first-born child is a boy relative to the first-born being a girl (Appendix Table A.11 shows that findings are stable when looking at the deprivation score). Māori men, on the other hand, are not observed to relocate to better neighbourhoods. This suggests that our key findings are likely to be driven by transitions out of socio-economically deprived neighbourhoods, which eventually reduces individuals' interaction with their criminal peers. However, the post-child birth neighbourhood adjustment of NZ European fathers seems to transpire more gradually compared to adjustments in their criminal behaviour, which can be a 
regarded as a more prompt process.

To test whether our classification of level of deprivation have any implications on our findings, we trial two alternative specifications (tables are available upon request). In the first specification, we additionally include deprivation score 8 to define high deprivation level. In the second specification, we restrict the definition of a highly deprived neighbourhoods to the score of 10 only. For NZ Europeans, the previous findings become further pronounced in the second specification. For example, the accumulated number of convictions drops by, on average, $51 \%$ points for fathers who lived in a highly deprived area and who had a serious conviction before birth - and by $22 \%$ points in non-deprived areas. Moreover, the probability of having a serious conviction drops by $23.5 \%$ points for fathers in highly deprived areas and by $6 \%$ points for relatively less deprived area. Finally, we observe that men who had a son and who resided in a highly deprived area are significantly less likely to be under similar deprived conditions during post-birth period starting from the fourth year onward. This is indicated by persistently significant point estimates. When defining a meshblock with a deprivation score of 8 and higher as highly deprived, the results hardly change compared to Table 5. Also, for Māori males, our results do not qualitatively vary with our findings in Appendix Table A.10 in any of the alternative specifications.

\subsection{Ethnic differences in conviction rates}

Next, we empirically verify whether our findings can be influenced by systematic differences in conviction rates between the two ethnic groups of NZ Europeans and Māori. One potential explanation is that there might be disproportionate ethnic differences in the likelihood of being charged of an offence compared to ethnically motivated disparities in receiving a different outcome for the same offence, e.g., being convicted or acquitted. The MoJ data set contains detailed information on the type of outcome of the charge. To test for systematic ethnic differences in outcome, we estimate the probability of being convicted (relative to being acquitted or dismissed) in the period of two years up to six months prior to child birth. Our finding from this additional analysis is presented in Appendix Table A.12. Column (1) of Table A.12 shows no significant impact of the ethnicity (measured as an indicator of being a Māori) on the likelihood of being convicted. This holds at the baseline as well as at each age category of the young fathers. Columns (2) to (5) of Table A.12 show regressions results of the probability of serious and non-serious convictions differentiated by ethnicity. The variables of interest are the type of crime (e.g. burglary or theft). The table shows that the coefficients are highly comparable 
across the two groups, indicating that for the same type of offence, conviction rates are similar. Reassuringly, as an additional support to the causal interpretation of our main identification strategy, the gender of the child has no impact on the probability of receiving a conviction relative to other possible outcomes.

\section{Labor market performance, education, and mar- riage}

By focusing on criminal convictions, the evidence presented in Section 5 reveals strong gender differences among NZ European fathers. We complement the analysis by examining whether the observed reduction in involvement in crime in substituted by more constructive time engagements. To test such a possibility of resource reallocation, we look at various life events including labor market outcomes measured in terms earnings from wages and salaries and labor market participation, the probability of marriage, and enrollment in tertiary education.

There are several theoretical explanations for why individuals might react differently depending on the gender of the child and how they re-allocate time and resource across alternative activities that may determine the child's upbringing. The model put forward by Dahl and Moretti (2008) highlights the possible channels in an utility maximizing framework to study family formation decisions. This can be applied in a broader context to derive implications on the allocation of time. Fathers might want to become a role model to their newborn, which might be more pronounced if the child is of their preferred gender. As such, young fathers may also derive more utility from spending time with a boy than a girl. If fathers tend to have a strong preference for sons, having a boy may prompt delinquent fathers to allocate time away from criminal activities or lessen interaction with criminal peers. It might also be the case that fathers have a comparative advantage in raising a boy than parenting a daughter.

There is an extensive literature in psychology, sociology, and economics describing the importance of the father on child development or investment decisions. Lamb (1976) provides an overview of the earlier literature in the related space. Empirical evidence supports the view that children raised in traditional family structure (usually refers to a two-parent household where both the biological parents are in a marital relationship) tend to have better developmental outcomes than those brought up by a single parent (McLanahan et al. 2005). Page and Stevens (2004) show that the absence of a father combined with lower levels of income in single-mother households have adverse economic implications for child development (McLanahan 
and Sandefur 2009). Lundberg et al. (2007) observed that fathers are more likely to stay in the household if the child is a boy and therefore in general, supports an interpretation of child gender effects based on parental beliefs about the importance of fathers for the long-term development of sons. In terms of investment decisions, Baker and Milligan (2016) documents that parental preferences (for investing) are not influenced by the gender of the child.

These are possible channels by which young fathers with a boy might reduce their criminal activity compared to young fathers with a girl. We use several outcome variables to provide more detailed insights into the effects found in Section 5. Although, analyzing outcomes such as labor market performance, family formation and educational attainment, are unlikely to provide an exhaustive point of view that could fully explain our main findings, focusing on those outcomes can definitely provide important suggestive evidence that could unfold some of the key mechanisms.

In Table 6 we provide the results using measures of labour market performance (such as accumulated income, mean earnings from wages and salaries, and employment spells) and indicators of being married and being enrolled in a tertiary (or college) education. We present our point estimates for all young fathers (Panels A-1 and A-2) and for young fathers with a serious conviction before birth (Panels B-1 and B-2) spanning over the period of ten years after child birth. Except for the effect on the probability of being married, which is positive and significant for NZ Europeans, we do not find any statistically relevant effects of the first child's gender in the full sample of young fathers.

Young fathers of European descent with a pre-birth serious conviction experience higher accumulated income after the birth of a son (Column (1) of Panel B-1). This effect can be driven by higher wages and/or higher labor market participation rates. Columns (2) to (4) provide results on average wages, months employed, and months receiving benefits. The table documents that the effect on accumulated income is driven by both, higher average wages and longer monthly spells in employment. Both point estimates become visible from the fourth year after birth with the point estimates being around $10 \%$ points for mean wages and $20 \%$ points for months employed (see Appendix Table A.14). Moreover, the table shows that young fathers with pre-birth serious convictions accumulate fewer months in receiving means tested benefits (Column (4) of Panel B-1). This observation might appeal to the role model hypothesis. To be specific, upon having a son, the NZ European fathers in the relevant sample seem to adjust their (labour market) behavior in a way can reveal their child gender preference in favour of sons. However, if raising a son is financially more demanding, socioeconomically vulnerable fathers may decide to supply more 
labour hours.

Table 6: Child-gender related difference in labor market indicators, education, and marriage rates, 10 years after birth

\begin{tabular}{|c|c|c|c|c|c|c|}
\hline & $\begin{array}{l}\text { Accumulated } \\
\text { Income } \\
(1)\end{array}$ & $\begin{array}{l}\text { Mean } \\
\text { wage } \\
(2)\end{array}$ & $\begin{array}{c}\text { Months } \\
\text { employed } \\
\text { (3) }\end{array}$ & $\begin{array}{l}\text { Month } \\
\text { benefits } \\
\text { (4) }\end{array}$ & $\begin{array}{c}\text { Married } \\
\text { (5) }\end{array}$ & $\begin{array}{c}\text { Education } \\
\text { (6) }\end{array}$ \\
\hline \multicolumn{7}{|c|}{ Panel A-1: Total sample NZ Europeans } \\
\hline Son & $\begin{array}{c}0.019 \\
(0.032)\end{array}$ & $\begin{array}{c}0.007 \\
(0.013)\end{array}$ & $\begin{array}{c}0.012 \\
(0.023)\end{array}$ & $\begin{array}{c}0.045 \\
(0.049)\end{array}$ & $\begin{array}{c}0.046^{* * *} \\
(0.017)\end{array}$ & $\begin{array}{l}-0.012 \\
(0.021)\end{array}$ \\
\hline Observations & 4404 & 4404 & 4404 & 4404 & 4404 & 4404 \\
\hline \multicolumn{7}{|c|}{ Panel A-2: Total sample Māori } \\
\hline Son & $\begin{array}{l}-0.001 \\
(0.0344)\end{array}$ & $\begin{array}{c}0.001 \\
(0.017)\end{array}$ & $\begin{array}{c}-0.001 \\
(0.030)\end{array}$ & $\begin{array}{l}-0.019 \\
(0.042)\end{array}$ & $\begin{array}{l}-0.004 \\
(0.011)\end{array}$ & $\begin{array}{c}0.020 \\
(0.023)\end{array}$ \\
\hline Observations & 3681 & 3681 & 3681 & 3681 & 3681 & 3681 \\
\hline \multicolumn{7}{|c|}{ Panel B-1: Pre-birth serious convictions sample NZ Europeans } \\
\hline Son & $\begin{array}{c}0.261^{* *} \\
(0.113)\end{array}$ & $\begin{array}{c}0.083^{* *} \\
(0.042)\end{array}$ & $\begin{array}{c}0.178^{* *} \\
(0.077)\end{array}$ & $\begin{array}{c}-0.179 * * \\
(0.085)\end{array}$ & $\begin{array}{c}0.026 \\
(0.028)\end{array}$ & $\begin{array}{l}-0.026 \\
(0.051)\end{array}$ \\
\hline Observations & 717 & 717 & 717 & 717 & 717 & 717 \\
\hline \multicolumn{7}{|c|}{ Panel B-2: Pre-birth serious convictions sample Māori } \\
\hline Son & $\begin{array}{c}0.026 \\
(0.114)\end{array}$ & $\begin{array}{l}-0.005 \\
(0.041)\end{array}$ & $\begin{array}{c}0.031 \\
(0.080)\end{array}$ & $\begin{array}{l}-0.035 \\
(0.069)\end{array}$ & $\begin{array}{c}0.013 \\
(0.016)\end{array}$ & $\begin{array}{c}0.027 \\
(0.052)\end{array}$ \\
\hline Observations & 807 & 807 & 807 & 807 & 807 & 807 \\
\hline
\end{tabular}

Notes: The table reports the results of the gender of the child on various labor market indicators, the probability of marriage, and enrolled in formal/non-formal tertiary qualifications at government-funded tertiary education organisations differentiated by ethnic group. Each coefficient corresponds to a separate regression. Accumulated income refers to the sum of monthly income from wages and salaries (log transformed). Mean wage refers the mean monthly income from wages and salaries (log transformed). Employed months are based on receiving income from wages and salaries (log transformed). Benefits refers to the number of months having received benefits. Marriage is a binary indicator on being married. Education is a binary indicator on being enrolled at tertiary education since birth of the child (only including individuals who were not enrolled before birth of the child). OLS regressions in columns (1) to (4). Probit regressions in columns (5) to (6). Robust standard errors in parentheses, significance level: ${ }^{* * *} \mathrm{p}<0.01,{ }^{* *} \mathrm{p}<0.05,{ }^{*} \mathrm{p}<0.1$.

Consistent with the above evidence on criminal activity, the effect of the gender of the first-born child on labor market indicators among Māori is overall not statistically significant. Overall, the behavioral adjustment after an exogenous shock again remains specific to certain ethnic groups only. ${ }^{15}$

Recent research on effects of child gender has found evidence that girls are disproportionately more likely to be raised by single-mothers. This might be consistent with the fact that fathers have preference for boys, or a stronger commitment to the well-being of sons (Morgan et al. 1988; Dahl and Moretti 2008). In our setting,

${ }^{15}$ While we could make stipulations about differences in access to resources of familial dynamics in the home, data limitations would impose several obstacles to identify the channels that lead young NZ European fathers to react more strongly to the birth of their first child than Māori fathers. 
Column (5) of Panel A-1 shows that marriage rates for NZ Europeans do adjust for the total sample (see Appendix Table A.13 for all ten years after child birth). However, unlike our findings with regard to criminal behaviour, among individuals with serious convictions before birth, we do not observe any differential marriage rates after child birth (Column (5) of Panel B-1). This may suggest that, pursuant to a reduction in crime of fathers whose first-born is a boy (Panel A-3 of Figure 6), the more economically disadvantaged group of pre-birth criminal offenders are more likely to prioritize financial benefits over marital commitments. However, in the total sample (especially for young fathers with no pre-birth criminal records), which on aggregate tends to have better economic conditions, relevance of marital relationship might be comparatively much larger. As such, for the NZ European fathers, while the behavioral adjustments post-child birth appear to be more pronounced in the pre-birth offenders' labor market engagements, for the broader sample, we find a more significant variation in marital relationships. Importantly, we do not find relevant differences in marriages rates among the group of Māori. ${ }^{16}$

Finally, column (6) of Table 6 provides the results for the effects of child's gender on being enrolled in tertiary education. Independent of the ethnicity, we do not find that the child's gender has any significant impact on the likelihood to be enrolled in tertiary education.

\section{Discussion and Conclusions}

In this paper we argue that ethnicities react very differently to major life events like the birth of a child. This has important implications as we implicitly argue that one-size-fits-all policy conclusion on crime reduction and otherwise are probably misguided. The paper is based on precise administrative data from New Zealand, and exploits a novel identification strategy proposed by Dustmann and Landers $\varnothing$ (2018) by using the random variation of the gender of their first child. We were able to demonstrate a stark ethnic divide in our results. For NZ Europeans, total convictions drop by $5 \%$ points for up to ten years after birth and can be as much as $13 \%$ points for those with any pre-birth criminal record. However, we find that any estimates for the Māori population are close to zero and not statistically significant. We also explore additional effects of the birth of a first child on labor market and social outcomes, again finding that only NZ European fathers experiences higher

\footnotetext{
${ }^{16}$ Marriage rates in New Zealand are relatively lower compared to other countries. One reason is that rules related to property division, maintenance and inheritance are the same for married and unmarried couples (Atkin 2008). The administrative data does not provide information on couples if two individuals are not married.
} 
average wages, more months in employment, and higher accumulated income.

Overall, these results point to differential behavior across ethnic groups with important policy implications. Differential behavior among NZ Europeans may not only imply different role models but comes along with higher financial resources at the household. The total effect of lower crime and higher income might therefore generate differential educational achievements of the child and their siblings. Māori do not react differentially and accumulated about $45 \%$ points more convictions for the ten years after birth. While it might indicate that Māori do not favor boys over girls or do not react as a role model differentially, it points to the fact that both gender (boys and girls of ethnic Māori) face harsher conditions to escape the cycle of criminal records and adverse labor market opportunities. Policies aiming to improve the prospects of children who are born in families with criminal records should take these results into account when designing policy interventions.

Our estimates illustrate the ethnic biases that may occur in research and have important implications for approaches to crime research and economic analysis more generally. There are many examples of implicit racial and gender biases in research and technology. In examining AI-facial analysis programs from major technology companies, Hardesty (2018) found that error rates are with $0.8 \%$ lowest for lightskinned men, but can be as much as $34 \%$ for darker-skinned women. Even recent studies of cutaneous manifestations of COVID-19 show racial biases. Though people of color have tended to be disproportionately impacted by COVID-19 in countries like the USA and UK, articles describing the virus' symptoms on a patient's skin almost exclusively show images from lighter-skinned patients (Lester et al. 2020). As the BLM movement brings these concerns of implicit biases and institutionalized racism to the forefront of social and political dialogue, we argue that economists will also need to do more to prevent potential biases in our own work.

Our results further serve as a warning that economists should be wary of generalizing the results of a majority population on a minority, as these groups may react very differently to a similar exogenous event. Thus, it would be wrong to draw conclusions and suggest policy responses from research that has not yet considered the diversity in a population, as a policy designed around the way a majority group reacts could be ineffective for minority groups, leaving them out from the potential benefits of research. 


\section{References}

Anker, A. S. T., Doleac, J. L. and Landers $\varnothing$, R. (forthcoming), 'The effects of dna databases on the deterrence and detection of offenders', American Economic Journal: Applied Economics .

Atkin, B. (2008), 'The legal world of unmarried couples: Reflections on de facto relationship in recent new zealand legislation', Victoria U. Wellington L. Rev. 39, 793.

Atkinson, J., Salmond, C. and Crampton, P. (2014), 'Nzdep2013 index of deprivation', Wellington: Department of Public Health, University of Otago .

Baker, M. and Milligan, K. (2016), 'Boy-girl differences in parental time investments: Evidence from three countries', Journal of Human Capital 10(4), 399-441.

Becker, G. S. (1968), 'Crime and punishment: An economic approach', Journal of Political Economy 76:2, 169-217.

Bhuller, M., Dahl, G. B., Loken, K. V. and Mogstad, M. (2018), Intergenerational effects of incarceration, in 'AEA Papers and Proceedings', Vol. 108, pp. 234-40.

Bhuller, M., Dahl, G. B., Løken, K. V. and Mogstad, M. (2020), 'Incarceration, recidivism, and employment', Journal of Political Economy 128(4), 1269-1324.

BJS (2019), 'Prisoners in 2017', Bureau of Justice Statistics . Available at: .

Chetty, R. and Hendren, N. (2018), 'The impacts of neighborhoods on intergenerational mobility ii: County-level estimates', The Quarterly Journal of Economics $\mathbf{1 3 3}(3), 1163-1228$.

Chetty, R., Hendren, N. and Katz, L. F. (2016), 'The effects of exposure to better neighborhoods on children: New evidence from the moving to opportunity experiment', American Economic Review 106(4), 855-902.

Corman, H., Noonan, K., Reichman, N. E. and Schwartz-Soicher, O. (2011), 'Life shocks and crime: A test of the "turning point" hypothesis', Demography 48.

Dahl, G. B. and Moretti, E. (2008), 'The demand for sons', The Review of Economic Studies 75, 1085-1120.

Dobbie, W., Grönqvist, H., Niknami, S., Palme, M. and Priks, M. (2018), The intergenerational effects of parental incarceration, Technical report, National Bureau of Economic Research. 
Durie, M. H. (1994), 'Whaiora: Māori health development', Auckland, N.Z: Oxford University Press .

Dustmann, C. and Landers $\varnothing$, R. (2018), 'Child's gender, young fathers' crime, and spillover effects in criminal behavior', Centre for Research and Analysis of Migration (CReAM), CPD 05/18.

Dyall, L. C. T. (1997), 'Pathway to māori mental health and wellness: Hauora o te hinengaro report of the 1997', Paper presented at the Hui Rangahau Hauora Hinengaro. Auckland, New Zealand: Health Research Council of New Zealand. .

Elkington, A. (2017), 'The everyday lives of young māori fathers: An explorative study', Journal of Indigenous Wellbeing 2:3, 3-17.

Farrington, D. P. (1986), Crime and Justice: An Annual Review of Research, Vol. 7, Chicago: University of Chicago Press, chapter Age and Crime, p. 189-250.

Farrington, D. P., Barnes, G. C. and Lambert, S. (1996), 'The concentration of offending in families', Legal and Criminological Psychology 1:1, 47-63.

Grogger, J. (1992), 'Arrests, persistent youth joblessness, and black/white employment differentials', The Review of Economics and Statistics 74:1, 100-106.

Grogger, J. (1995), 'The effect of arrests on the employment and earnings of young men', The Quarterly Journal of Economics 110:1, 51-71.

Groot, S. A. M. (2006), 'Cultural vehicles and the māori print media: what cultural concepts are used to communicate health messages to māori?', Mai Review 1:1, 16.

Hardesty, L. (2018), 'Study finds gender and skin-type bias in commercial artificialintelligence systems', MIT News Office.

URL: $\quad h t t p: / / n e w s . m i t . e d u / 2018 /$ study-finds-gender-skin-type-bias-artificialintelligence-systems-0212

Johnston, P. and Pihama, L. (1994), 'The marginalization of maori women', Hecate $20: 2,83$.

Karena, R. (2012), 'Takitoru: From parallel to partnership', Mai Journal 1(1), 6175.

Katz, L. F., Kling, J. R. and Liebman, J. B. (2001), 'Moving to opportunity in boston: Early results of a randomized mobility experiment', The Quarterly Journal of Economics 116(2), 607-654. 
Kingi, T. (2011), Māori and Social Issues, Vol. 1, Wellington, New Zealand: Ngā Pae o te Māramatanga Huia Publishers, chapter Māori mental health: Past, present and future, p. 89-108.

Kling, J. R., Liebman, J. B. and Katz, L. F. (2007), 'Experimental analysis of neighborhood effects', Econometrica 75(1), 83-119.

Kling, J. R., Ludwig, J. and Katz, L. F. (2005), 'Neighborhood effects on crime for female and male youth: Evidence from a randomized housing voucher experiment', The Quarterly Journal of Economics 120(1), 87-130.

Lamb, M. E. (1976), 'The role of the father: An overview', The role of the father in child development. New York: Wiley pp. 1-63.

Larson, N. C., Hussey, J. M., Gillmore, M. R. and Gilchrist, L. D. (1996), 'What about dad? Fathers of children born to school-age mothers', Families in Society $77: 5,279-289$.

Lester, J., Jia, J., Zhang, L., Okoye, G. and Linos, E. (2020), 'Absence of images of skin of colour in publications of covid-19 skin manifestations', British Journal of Dermatology p. 1-2.

Loeber, R. (2012), The Future of Criminology, Oxford University Press, chapter Does the Study of the Age-crime curve have a future?, p. 11-19.

Ludwig, J., Duncan, G. J., Gennetian, L. A., Katz, L. F., Kessler, R. C., Kling, J. R. and Sanbonmatsu, L. (2012), 'Neighborhood effects on the long-term well-being of low-income adults', Science 337(6101), 1505-1510.

Lundberg, S. (2005), 'Sons, daughters, and parental behaviour', Oxford Review of Economic Policy 21(3), 340-356.

Lundberg, S., McLanahan, S. and Rose, E. (2007), 'Child gender and father involvement in fragile families', Demography 44(1), 79-92.

Mammen, K. (2008), 'The effect of children's gender on living arrangements and child support', American Economic Review 98(2), 408-12.

McIntosh, T. and Workman, K. (2017), The Palgrave handbook of Australian and New Zealand criminology, crime and justice, Palgrave Macmillan, Cham, chapter Māori and prison, pp. 725-735. 
McLanahan, S., Donahue, E. and Haskins, R. (2005), 'Introducing the issue', The Future of Children pp. 3-12.

McLanahan, S. and Sandefur, G. (2009), Growing up with a single parent: What hurts, what helps, Harvard University Press.

MoJ (2020a), 'Children adopted', Ministry of Justice . Available at: https://www.justice.govt.nz/justice-sector-policy/research-data/justicestatistics/data-tables/processes.

MoJ (2020b), 'Children and young people in court', Ministry of Justice. Available at: https://www.justice.govt.nz/assets/Documents/Publications/32n83uChildren-and-young-people-data-notes-and-trends-dec2019-v1.0.pdf.pdf.

Morgan, S. P., Lye, D. N. and Condran, G. A. (1988), 'Sons, daughters, and the risk of marital disruption', American journal of sociology 94(1), 110-129.

Norris, S., Pecenco, M. and Weaver, J. (2020), 'The effects of parental and sibling incarceration: Evidence from ohio', Available at SSRN 3590735.

Page, M. E. and Stevens, A. H. (2004), 'The economic consequences of absent parents', Journal of Human Resources 39(1), 80-107.

Pihama, L., Reynolds, P., Smith, C., Reid, J., Smith, L. T. and Nana, R. T. (2014), 'Positioning historical trauma theory within aotearoa new zealand', AlterNative: An International Journal of Indigenous Peoples 10(3), 248-262.

Popper, K. (2013), Realism and the aim of science: From the postscript to the logic of scientific discovery, Routledge.

Pratt, J. (2006), 'The dark side of paradise: Explaining new zealand's history of high imprisonment', The British Journal of Criminology 46:4, 541-560.

Quince, K. (2007), The New Zealand criminal justice system, Auckland, New Zealand: LexisNexis, chapter Māori and the criminal justice system in New Zealand, p. 333-358.

Roberts, J. V. (2003), 'Sentencing reform in new zealand: an analysis of the sentencing act 2002', Australian \& New Zealand Journal of Criminology 36(3), 249-271.

Sampson, R. J. and Laub, J. H. (1990), 'Crime and deviance over the life course: The salience of adult social bonds', American Sociological Review 55:6, 609-627. 
StatsNZ (2019), 'New zealand's population reflects growing diversity', New Zealand Government . Available at: https://www.stats.govt.nz/news/new-zealandspopulation-reflects-growing-diversity.

StatsNZ (2020), 'Births and deaths: Year ended december 2010', New Zealand Government . Available at: http://archive.stats.govt.nz/browse_for_stats/population/births/BirthsAndDeaths_HOTPYeDec10/Commentary.aspxgsc.tab=0.

Wall, M. (1997), 'Stereotypical constructions of the maori 'race' in the media', New Zealand Geographer 53:2, 40-45.

Weinman, M. L., Smith, P. B. and Buzi, R. S. (2002), 'Young father: An analysis of risk behaviors and service needs', Child and Adolescent Social Work Journal 19:6, 437-453.

Weinmann, C. M., Agurcia, C. A., Rickert, V. I., Berenson, A. B. and Volk, R. J. (2006), 'Child and adolescent social work journal', Child and Adolescent Social Work Journal 23:5-6, 617-634.

Western, B., Kling, J. R. and F, W. D. (2001), 'The labor market consequences of incarceration', Crime and Delinquency 47:3, 410-426.

Worthen, M. G. (2011), 'Gender differences in parent-child bonding: implications for understanding the gender gap in delinquency', Journal of Crime and Justice $34: 1,2-23$. 


\section{Supplementary Appendix}

\section{A Data Addendum}

Table A.1: The gender of the child

\begin{tabular}{|c|c|c|c|}
\hline & Total Sample & Māori & NZ European \\
\hline NZ European & $\begin{array}{r}0.00700 \\
(0.0147)\end{array}$ & & \\
\hline \multicolumn{4}{|c|}{ Birthyear (reference: 2005) } \\
\hline 2006 & $\begin{array}{r}-0.0168 \\
(0.0139)\end{array}$ & $\begin{array}{l}0.00146 \\
(0.0382)\end{array}$ & $\begin{array}{l}-0.0200 \\
(0.0150)\end{array}$ \\
\hline 2007 & $\begin{array}{c}-0.00274 \\
(0.0138)\end{array}$ & $\begin{array}{c}0.0109 \\
(0.0378)\end{array}$ & $\begin{array}{r}-0.00495 \\
(0.0149)\end{array}$ \\
\hline 2008 & $\begin{array}{l}0.00531 \\
(0.0139)\end{array}$ & $\begin{array}{l}0.00604 \\
(0.0381)\end{array}$ & $\begin{array}{l}0.00519 \\
(0.0150)\end{array}$ \\
\hline 2009 & $\begin{array}{c}0.0231 \\
(0.0179)\end{array}$ & $\begin{array}{c}0.0268 \\
(0.0491)\end{array}$ & $\begin{array}{c}0.0217 \\
(0.0192)\end{array}$ \\
\hline \multicolumn{4}{|c|}{ Birthmonth (reference: January) } \\
\hline February & $\begin{array}{l}-0.0211 \\
(0.0215)\end{array}$ & $\begin{array}{c}0.0341 \\
(0.0595)\end{array}$ & $\begin{array}{l}-0.0296 \\
(0.0231)\end{array}$ \\
\hline March & $\begin{array}{l}-0.00193 \\
(0.0211)\end{array}$ & $\begin{array}{c}0.0220 \\
(0.0584)\end{array}$ & $\begin{array}{l}-0.00567 \\
(0.0226)\end{array}$ \\
\hline April & $\begin{array}{l}-0.00800 \\
(0.0213)\end{array}$ & $\begin{array}{l}-0.0304 \\
(0.0578)\end{array}$ & $\begin{array}{l}-0.00382 \\
(0.0230)\end{array}$ \\
\hline May & $\begin{array}{c}0.0176 \\
(0.0212)\end{array}$ & $\begin{array}{l}0.00262 \\
(0.0578)\end{array}$ & $\begin{array}{c}0.0205 \\
(0.0227)\end{array}$ \\
\hline June & $\begin{array}{l}-0.0176 \\
(0.0214)\end{array}$ & $\begin{array}{c}0.0271 \\
(0.0593)\end{array}$ & $\begin{array}{l}-0.0246 \\
(0.0230)\end{array}$ \\
\hline July & $\begin{array}{l}0.00697 \\
(0.0228)\end{array}$ & $\begin{array}{c}0.0569 \\
(0.0621)\end{array}$ & $\begin{array}{l}-0.00150 \\
(0.0245)\end{array}$ \\
\hline August & $\begin{array}{c}0.0368 \\
(0.0228)\end{array}$ & $\begin{array}{c}0.000834 \\
(0.0617)\end{array}$ & $\begin{array}{l}0.0433^{*} \\
(0.0246)\end{array}$ \\
\hline September & $\begin{array}{c}0.0474^{* *} \\
(0.0228)\end{array}$ & $\begin{array}{c}0.0290 \\
(0.0623)\end{array}$ & $\begin{array}{c}0.0503^{* *} \\
(0.0245)\end{array}$ \\
\hline October & $\begin{array}{l}0.00839 \\
(0.0227)\end{array}$ & $\begin{array}{c}0.0496 \\
(0.0625)\end{array}$ & $\begin{array}{l}0.00168 \\
(0.0244)\end{array}$ \\
\hline November & 0.0126 & 0.0719 & 0.00339 \\
\hline
\end{tabular}


Table A.1 - continued from previous page

\begin{tabular}{|c|c|c|c|}
\hline Variable & Total Sample & Māori & NZ European \\
\hline & $(0.0228)$ & $(0.0626)$ & $(0.0245)$ \\
\hline \multirow[t]{2}{*}{ December } & 0.00641 & $0.110^{*}$ & -0.00989 \\
\hline & $(0.0228)$ & $(0.0625)$ & $(0.0245)$ \\
\hline \multicolumn{4}{|c|}{ Age of father (reference: 18 years old) } \\
\hline \multirow[t]{2}{*}{19} & 0.0427 & 0.0417 & 0.0451 \\
\hline & $(0.0434)$ & $(0.0590)$ & $(0.0647)$ \\
\hline \multirow[t]{2}{*}{20} & 0.0177 & 0.0112 & 0.0226 \\
\hline & $(0.0423)$ & $(0.0591)$ & $(0.0617)$ \\
\hline \multirow[t]{2}{*}{21} & -0.00498 & -0.0463 & 0.0199 \\
\hline & $(0.0419)$ & $(0.0605)$ & $(0.0603)$ \\
\hline \multirow[t]{2}{*}{22} & -0.0318 & -0.000993 & -0.0443 \\
\hline & $(0.0421)$ & $(0.0631)$ & $(0.0598)$ \\
\hline \multirow[t]{2}{*}{23} & -0.0118 & -0.0333 & -0.00103 \\
\hline & $(0.0419)$ & $(0.0640)$ & $(0.0592)$ \\
\hline \multirow[t]{2}{*}{24} & -0.0424 & -0.0218 & -0.0472 \\
\hline & $(0.0417)$ & $(0.0670)$ & $(0.0585)$ \\
\hline \multirow[t]{2}{*}{25} & -0.0122 & $0.115^{*}$ & -0.0423 \\
\hline & $(0.0412)$ & $(0.0695)$ & $(0.0576)$ \\
\hline \multirow[t]{2}{*}{26} & 0.00199 & 0.0246 & -0.000368 \\
\hline & $(0.0411)$ & $(0.0743)$ & $(0.0571)$ \\
\hline \multirow[t]{2}{*}{27} & $-0.0670^{*}$ & -0.0576 & -0.0665 \\
\hline & $(0.0404)$ & $(0.0742)$ & $(0.0563)$ \\
\hline \multirow[t]{2}{*}{28} & -0.0486 & $-0.154^{*}$ & -0.0347 \\
\hline & $(0.0398)$ & $(0.0795)$ & $(0.0556)$ \\
\hline \multirow[t]{2}{*}{29} & -0.0420 & -0.0500 & -0.0393 \\
\hline & $(0.0393)$ & $(0.0797)$ & $(0.0551)$ \\
\hline \multirow[t]{2}{*}{30} & 0.0186 & 0.0167 & 0.0208 \\
\hline & $(0.0390)$ & $(0.0861)$ & $(0.0547)$ \\
\hline \multirow[t]{2}{*}{31} & -0.0157 & -0.0255 & -0.0130 \\
\hline & $(0.0387)$ & $(0.0890)$ & $(0.0544)$ \\
\hline \multirow[t]{2}{*}{32} & -0.00807 & -0.0253 & -0.00507 \\
\hline & $(0.0385)$ & $(0.0928)$ & $(0.0543)$ \\
\hline \multirow[t]{2}{*}{33} & -0.00217 & -0.0175 & 0.000620 \\
\hline & $(0.0386)$ & $(0.0943)$ & $(0.0543)$ \\
\hline \multirow[t]{2}{*}{34} & -0.0226 & -0.137 & -0.0150 \\
\hline & $(0.0391)$ & $(0.103)$ & $(0.0547)$ \\
\hline
\end{tabular}


Table A.1 - continued from previous page

\begin{tabular}{|c|c|c|c|}
\hline Variable & Total Sample & Māori & NZ European \\
\hline \multirow[t]{2}{*}{35} & -0.0555 & -0.126 & -0.0497 \\
\hline & $(0.0393)$ & $(0.105)$ & $(0.0548)$ \\
\hline \multirow[t]{2}{*}{36} & -0.0367 & $-0.191^{*}$ & -0.0270 \\
\hline & $(0.0398)$ & $(0.107)$ & $(0.0552)$ \\
\hline \multirow[t]{2}{*}{37} & -0.0383 & 0.107 & -0.0435 \\
\hline & $(0.0411)$ & $(0.116)$ & $(0.0562)$ \\
\hline \multirow[t]{2}{*}{38} & -0.00260 & 0.0604 & -0.00363 \\
\hline & $(0.0425)$ & $(0.127)$ & $(0.0572)$ \\
\hline \multirow[t]{2}{*}{39} & $-0.0946^{* *}$ & -0.0620 & -0.0944 \\
\hline & $(0.0439)$ & $(0.132)$ & $(0.0584)$ \\
\hline \multirow[t]{2}{*}{40} & 0.00129 & 0.0860 & -0.000401 \\
\hline & $(0.0462)$ & $(0.155)$ & $(0.0602)$ \\
\hline \multirow[t]{2}{*}{41} & -0.0347 & 0.0702 & -0.0367 \\
\hline & $(0.0490)$ & $(0.181)$ & $(0.0624)$ \\
\hline \multirow[t]{2}{*}{42} & 0.0478 & -0.161 & 0.0596 \\
\hline & $(0.0516)$ & $(0.187)$ & $(0.0646)$ \\
\hline \multirow[t]{2}{*}{43} & 0.0414 & 0.0134 & 0.0454 \\
\hline & $(0.0566)$ & $(0.208)$ & $(0.0690)$ \\
\hline \multirow[t]{2}{*}{44} & -0.0649 & -0.158 & -0.0567 \\
\hline & $(0.0613)$ & $(0.206)$ & $(0.0734)$ \\
\hline \multirow[t]{2}{*}{ Constant } & 0.0487 & 0.0214 & 0.0582 \\
\hline & $(0.0377)$ & $(0.0639)$ & $(0.0542)$ \\
\hline
\end{tabular}

Notes: The table shows probit regression results (marginal effects) of the gender of the child on the years of birth, month of birth, and the age of the father. Column (1) refers to the full sample. Column (2) refers to the ethnic group of Māori. Column (3) refers to the ethnic group of NZ Europeans. Significance level: ${ }^{* * *} \mathrm{p}<0.01,{ }^{* *} \mathrm{p}<0.05,{ }^{*} \mathrm{p}<0.1$. 
Table A.2: Distribution of convictions

\begin{tabular}{|c|c|c|c|c|c|c|}
\hline \multirow[t]{2}{*}{ Years to birth } & \multicolumn{3}{|c|}{ NZ European } & \multicolumn{3}{|c|}{ Māori } \\
\hline & $\begin{array}{c}\text { daughter } \\
\text { (1) }\end{array}$ & $\begin{array}{l}\text { son } \\
(2)\end{array}$ & $\begin{array}{c}p \text {-value } \\
(3)\end{array}$ & $\begin{array}{c}\text { daughter } \\
\text { (4) }\end{array}$ & $\begin{array}{l}\text { son } \\
(5)\end{array}$ & $\begin{array}{c}p \text {-value } \\
(6)\end{array}$ \\
\hline \multicolumn{7}{|c|}{ Panel A: All convictions } \\
\hline pre-birth & $\begin{array}{c}0.428 \\
(0.697)\end{array}$ & $\begin{array}{c}0.407 \\
(0.672)\end{array}$ & 0.319 & $\begin{array}{c}0.487 \\
(0.705)\end{array}$ & $\begin{array}{c}0.502 \\
(0.722)\end{array}$ & 0.539 \\
\hline 1 & $\begin{array}{c}0.265 \\
(0.553)\end{array}$ & $\begin{array}{c}0.217 \\
(0.482)\end{array}$ & 0.002 & $\begin{array}{c}0.395 \\
(0.641)\end{array}$ & $\begin{array}{c}0.385 \\
(0.636)\end{array}$ & 0.647 \\
\hline 2 & $\begin{array}{l}0.427 \\
(0.72)\end{array}$ & $\begin{array}{l}0.361 \\
(0.65)\end{array}$ & 0.001 & $\begin{array}{c}0.634 \\
(0.815)\end{array}$ & $\begin{array}{c}0.624 \\
(0.793)\end{array}$ & 0.726 \\
\hline 3 & $\begin{array}{c}0.539 \\
(0.821)\end{array}$ & $\begin{array}{c}0.48 \\
(0.76)\end{array}$ & 0.013 & $\begin{array}{c}0.809 \\
(0.912)\end{array}$ & $\begin{array}{c}0.789 \\
(0.896)\end{array}$ & 0.501 \\
\hline 4 & $\begin{array}{c}0.618 \\
(0.893)\end{array}$ & $\begin{array}{c}0.56 \\
(0.826)\end{array}$ & 0.025 & $\begin{array}{c}0.93 \\
(0.976)\end{array}$ & $\begin{array}{c}0.907 \\
(0.957)\end{array}$ & 0.488 \\
\hline 5 & $\begin{array}{c}0.681 \\
(0.945)\end{array}$ & $\begin{array}{c}0.62 \\
(0.876)\end{array}$ & 0.028 & $\begin{array}{c}1.026 \\
(1.027)\end{array}$ & $\begin{array}{c}1.009 \\
(1.005)\end{array}$ & 0.628 \\
\hline 6 & $\begin{array}{c}0.728 \\
(0.986)\end{array}$ & $\begin{array}{c}0.672 \\
(0.916)\end{array}$ & 0.051 & $\begin{array}{c}1.096 \\
(1.068)\end{array}$ & $\begin{array}{c}1.096 \\
(1.044)\end{array}$ & 0.982 \\
\hline 7 & $\begin{array}{c}0.764 \\
(1.015)\end{array}$ & $\begin{array}{c}0.709 \\
(0.944)\end{array}$ & 0.069 & $\begin{array}{c}1.161 \\
(1.103)\end{array}$ & $\begin{array}{c}1.166 \\
(1.076)\end{array}$ & 0.88 \\
\hline 8 & $\begin{array}{c}0.794 \\
(1.039)\end{array}$ & $\begin{array}{c}0.74 \\
(0.967)\end{array}$ & 0.076 & $\begin{array}{c}1.216 \\
(1.136)\end{array}$ & $\begin{array}{c}1.226 \\
(1.104)\end{array}$ & 0.78 \\
\hline 9 & $\begin{array}{c}0.819 \\
(1.062)\end{array}$ & $\begin{array}{c}0.766 \\
(0.991)\end{array}$ & 0.094 & $\begin{array}{c}1.271 \\
(1.163)\end{array}$ & $\begin{array}{c}1.276 \\
(1.128)\end{array}$ & 0.908 \\
\hline 10 & $\begin{array}{c}0.846 \\
(1.082)\end{array}$ & $\begin{array}{l}0.785 \\
(1.01)\end{array}$ & 0.058 & $\begin{array}{c}1.32 \\
(1.191)\end{array}$ & $\begin{array}{c}1.321 \\
(1.157)\end{array}$ & 0.992 \\
\hline Panel B: Ser & ious sent & nce con & ictions & & & \\
\hline pre-birth & $\begin{array}{c}0.232 \\
(0.573)\end{array}$ & $\begin{array}{l}0.213 \\
(0.55)\end{array}$ & 0.265 & $\begin{array}{c}0.29 \\
(0.605)\end{array}$ & $\begin{array}{l}0.291 \\
(0.62)\end{array}$ & 0.958 \\
\hline 1 & $\begin{array}{c}0.171 \\
(0.475)\end{array}$ & $\begin{array}{c}0.125 \\
(0.391)\end{array}$ & 0 & $\begin{array}{c}0.266 \\
(0.571)\end{array}$ & $\begin{array}{c}0.267 \\
(0.569)\end{array}$ & 0.918 \\
\hline 2 & $\begin{array}{c}0.276 \\
(0.628)\end{array}$ & $\begin{array}{c}0.217 \\
(0.541)\end{array}$ & 0.001 & $\begin{array}{c}0.444 \\
(0.741)\end{array}$ & $\begin{array}{c}0.433 \\
(0.73)\end{array}$ & 0.645 \\
\hline 3 & $\begin{array}{c}0.359 \\
(0.721)\end{array}$ & $\begin{array}{l}0.295 \\
(0.65)\end{array}$ & 0.002 & $\begin{array}{c}0.574 \\
(0.853)\end{array}$ & $\begin{array}{c}0.562 \\
(0.841)\end{array}$ & 0.665 \\
\hline
\end{tabular}

Continued on next page 
Table A.2 - continued from previous page

\begin{tabular}{lcccccc}
\hline \multirow{2}{*}{ Years to birth } & \multicolumn{3}{c}{ NZ European } & \multicolumn{3}{c}{ Māori } \\
\cline { 2 - 7 } & daughter & son & $p$-value & daughter & son & $p$-value \\
& $(1)$ & $(2)$ & $(3)$ & $(4)$ & $(5)$ & $(6)$ \\
\hline 4 & 0.425 & 0.354 & 0.002 & 0.678 & 0.657 & 0.508 \\
& $(0.796)$ & $(0.72)$ & & $(0.924)$ & $(0.909)$ & \\
5 & 0.477 & 0.4 & 0.002 & 0.758 & 0.743 & 0.648 \\
& $(0.853)$ & $(0.773)$ & & $(0.985)$ & $(0.965)$ & \\
6 & 0.516 & 0.441 & 0.004 & 0.822 & 0.819 & 0.928 \\
& $(0.897)$ & $(0.815)$ & & $(1.032)$ & $(1.012)$ & \\
7 & 0.548 & 0.466 & 0.003 & 0.883 & 0.878 & 0.905 \\
& $(0.929)$ & $(0.846)$ & & $(1.071)$ & $(1.052)$ & \\
& 0.574 & 0.491 & 0.003 & 0.931 & 0.934 & 0.943 \\
9 & $(0.955)$ & $(0.873)$ & & $(1.111)$ & $(1.085)$ & \\
& 0.596 & 0.515 & 0.005 & 0.979 & 0.979 & 0.993 \\
\multirow{4}{*}{10} & $(0.982)$ & $(0.899)$ & & $(1.145)$ & $(1.112)$ & \\
& 0.616 & 0.532 & 0.004 & 1.026 & 1.025 & 0.975 \\
& $(1.003)$ & $(0.919)$ & & $(1.176)$ & $(1.143)$ &
\end{tabular}

\section{Panel C: Non-serious sentence convictions}

\begin{tabular}{lcccccc} 
pre-birth & 0.261 & 0.251 & 0.436 & 0.264 & 0.284 & 0.198 \\
& $(0.468)$ & $(0.456)$ & & $(0.455)$ & $(0.466)$ & \\
1 & 0.124 & 0.113 & 0.25 & 0.169 & 0.161 & 0.468 \\
\multirow{4}{*}{2} & $(0.317)$ & $(0.306)$ & & $(0.363)$ & $(0.352)$ & \\
& 0.218 & 0.196 & 0.092 & 0.297 & 0.288 & 0.541 \\
3 & $(0.43)$ & $(0.416)$ & & $(0.477)$ & $(0.46)$ & \\
& 0.285 & 0.268 & 0.269 & 0.397 & 0.377 & 0.246 \\
4 & $(0.503)$ & $(0.481)$ & & $(0.539)$ & $(0.523)$ & \\
& 0.329 & 0.316 & 0.399 & 0.466 & 0.444 & 0.234 \\
5 & $(0.545)$ & $(0.52)$ & & $(0.581)$ & $(0.565)$ & \\
& 0.366 & 0.353 & 0.474 & 0.524 & 0.502 & 0.282 \\
6 & $(0.572)$ & $(0.551)$ & & $(0.611)$ & $(0.598)$ & \\
& 0.396 & 0.386 & 0.581 & 0.565 & 0.551 & 0.522 \\
7 & $(0.593)$ & $(0.575)$ & & $(0.634)$ & $(0.622)$ & \\
& 0.418 & 0.414 & 0.801 & 0.602 & 0.596 & 0.778 \\
8 & $(0.609)$ & $(0.594)$ & & $(0.653)$ & $(0.641)$ & \\
& 0.435 & 0.432 & 0.857 & 0.636 & 0.632 & 0.866 \\
& $(0.621)$ & $(0.605)$ & & $(0.669)$ & $(0.657)$ & \\
\hline
\end{tabular}


Table A.2 - continued from previous page

\begin{tabular}{lcccccc}
\hline Years to birth & \multicolumn{3}{c}{ NZ European } & \multicolumn{3}{c}{ Māori } \\
\cline { 2 - 7 } & daughter & son & $p$-value & daughter & son & $p$-value \\
& $(1)$ & $(2)$ & $(3)$ & $(4)$ & $(5)$ & $(6)$ \\
\hline 9 & 0.449 & 0.447 & 0.914 & 0.672 & 0.665 & 0.779 \\
& $(0.634)$ & $(0.618)$ & & $(0.684)$ & $(0.675)$ & \\
10 & 0.471 & 0.46 & 0.589 & 0.701 & 0.693 & 0.743 \\
& $(0.648)$ & $(0.63)$ & & $(0.697)$ & $(0.688)$ & \\
Observations & \multicolumn{3}{c}{4404} & \multicolumn{3}{c}{3681} \\
\hline
\end{tabular}

Notes: The table shows log-transformed accumulated numbers of convictions $(+1)$ for individuals who fathers a girl (columns (1) and (4)) and who father a boy (column (2) and (5)), differentiated by ethnic group. The $p$-values in columns (3) and (6) corresponds to a standard $t$-test. Panel A to C differentiate convictions type. Panel A refers to all convictions. Panel B refers to serious convictions. Panel $\mathrm{C}$ refers to non-serious conviction. Standard errors in parentheses. Significance level: *** $\mathrm{p}<0.01,{ }^{* *} \mathrm{p}<0.05,{ }^{*} \mathrm{p}<0.1$. 
Table A.3: Distribution of convictions for different pre-birth ranks

\begin{tabular}{|c|c|c|c|c|c|c|}
\hline \multirow[t]{2}{*}{ Years to birth } & \multicolumn{3}{|c|}{ NZ European } & \multicolumn{3}{|c|}{ Māori } \\
\hline & $\begin{array}{c}\text { daughter } \\
\text { (1) }\end{array}$ & $\begin{array}{l}\text { son } \\
(2)\end{array}$ & $\begin{array}{c}p \text {-value } \\
(3)\end{array}$ & $\begin{array}{c}\text { daughter } \\
\text { (4) }\end{array}$ & $\begin{array}{l}\text { son } \\
(5)\end{array}$ & $\begin{array}{c}p \text {-value } \\
(6)\end{array}$ \\
\hline \multicolumn{7}{|c|}{ Panel A: conviction before birth } \\
\hline pre-birth & $\begin{array}{c}1.272 \\
(0.608)\end{array}$ & $\begin{array}{c}1.221 \\
(0.599)\end{array}$ & 0.105 & $\begin{array}{l}1.256 \\
(0.56)\end{array}$ & $\begin{array}{c}1.266 \\
(0.588)\end{array}$ & 0.743 \\
\hline 1 & $\begin{array}{c}0.562 \\
(0.732)\end{array}$ & $\begin{array}{c}0.446 \\
(0.643)\end{array}$ & 0.001 & $\begin{array}{c}0.683 \\
(0.742)\end{array}$ & $\begin{array}{c}0.661 \\
(0.761)\end{array}$ & 0.577 \\
\hline 2 & $\begin{array}{c}0.861 \\
(0.885)\end{array}$ & $\begin{array}{c}0.712 \\
(0.819)\end{array}$ & 0.001 & $\begin{array}{c}1.086 \\
(0.863)\end{array}$ & $\begin{array}{c}1.022 \\
(0.885)\end{array}$ & 0.165 \\
\hline 3 & $\begin{array}{c}1.055 \\
(0.976)\end{array}$ & $\begin{array}{c}0.922 \\
(0.914)\end{array}$ & 0.007 & $\begin{array}{c}1.353 \\
(0.913)\end{array}$ & $\begin{array}{c}1.258 \\
(0.957)\end{array}$ & 0.056 \\
\hline 4 & $\begin{array}{c}1.202 \\
(1.034)\end{array}$ & $\begin{array}{c}1.066 \\
(0.969)\end{array}$ & 0.01 & $\begin{array}{c}1.519 \\
(0.948)\end{array}$ & $\begin{array}{c}1.432 \\
(0.994)\end{array}$ & 0.093 \\
\hline 5 & $\begin{array}{c}1.305 \\
(1.074)\end{array}$ & $\begin{array}{c}1.167 \\
(1.016)\end{array}$ & 0.012 & $\begin{array}{l}1.643 \\
(0.98)\end{array}$ & $\begin{array}{l}1.569 \\
(1.01)\end{array}$ & 0.167 \\
\hline 6 & $\begin{array}{c}1.382 \\
(1.108)\end{array}$ & $\begin{array}{c}1.252 \\
(1.049)\end{array}$ & 0.022 & $\begin{array}{c}1.742 \\
(1.004)\end{array}$ & $\begin{array}{c}1.681 \\
(1.021)\end{array}$ & 0.261 \\
\hline 7 & $\begin{array}{c}1.449 \\
(1.125)\end{array}$ & $\begin{array}{c}1.309 \\
(1.077)\end{array}$ & 0.016 & $\begin{array}{c}1.839 \\
(1.024)\end{array}$ & $\begin{array}{c}1.776 \\
(1.039)\end{array}$ & 0.254 \\
\hline 8 & $\begin{array}{c}1.496 \\
(1.145)\end{array}$ & $\begin{array}{c}1.354 \\
(1.095)\end{array}$ & 0.016 & $\begin{array}{c}1.923 \\
(1.054)\end{array}$ & $\begin{array}{c}1.853 \\
(1.055)\end{array}$ & 0.216 \\
\hline 9 & $\begin{array}{l}1.538 \\
(1.17)\end{array}$ & $\begin{array}{c}1.395 \\
(1.113)\end{array}$ & 0.019 & $\begin{array}{c}1.999 \\
(1.075)\end{array}$ & $\begin{array}{c}1.915 \\
(1.074)\end{array}$ & 0.143 \\
\hline 10 & $\begin{array}{c}1.581 \\
(1.183)\end{array}$ & $\begin{array}{c}1.424 \\
(1.135)\end{array}$ & 0.011 & $\begin{array}{c}2.065 \\
(1.093)\end{array}$ & $\begin{array}{c}1.973 \\
(1.103)\end{array}$ & 0.121 \\
\hline Panel B: pre & birth seri & ous sent & ence con & victions & & \\
\hline pre-birth & $\begin{array}{c}1.639 \\
(0.606)\end{array}$ & $\begin{array}{c}1.58 \\
(0.63)\end{array}$ & 0.205 & $\begin{array}{c}1.527 \\
(0.561)\end{array}$ & $\begin{array}{c}1.573 \\
(0.588)\end{array}$ & 0.252 \\
\hline 1 & $\begin{array}{c}0.833 \\
(0.806)\end{array}$ & $\begin{array}{c}0.636 \\
(0.707)\end{array}$ & 0.001 & $\begin{array}{c}0.837 \\
(0.769)\end{array}$ & $\begin{array}{c}0.837 \\
(0.811)\end{array}$ & 0.989 \\
\hline 2 & $\begin{array}{c}1.216 \\
(0.925)\end{array}$ & $\begin{array}{c}0.986 \\
(0.876)\end{array}$ & 0.001 & $\begin{array}{c}1.277 \\
(0.869)\end{array}$ & $\begin{array}{c}1.23 \\
(0.918)\end{array}$ & 0.457 \\
\hline 3 & $\begin{array}{c}1.448 \\
(0.979)\end{array}$ & $\begin{array}{c}1.244 \\
(0.937)\end{array}$ & 0.005 & $\begin{array}{c}1.587 \\
(0.887)\end{array}$ & $\begin{array}{c}1.511 \\
(0.971)\end{array}$ & 0.251 \\
\hline
\end{tabular}

Continued on next page 
Table A.3 - continued from previous page

\begin{tabular}{lcccccc}
\hline \multirow{2}{*}{ Years to birth } & \multicolumn{3}{c}{ NZ European } & \multicolumn{3}{c}{ Māori } \\
\cline { 2 - 7 } & daughter & son & $p$-value & daughter & son & $p$-value \\
& $(1)$ & $(2)$ & $(3)$ & $(4)$ & $(5)$ & $(6)$ \\
\hline 4 & 1.63 & 1.415 & 0.004 & 1.774 & 1.692 & 0.225 \\
& $(1.012)$ & $(0.968)$ & & $(0.902)$ & $(0.992)$ & \\
5 & 1.748 & 1.553 & 0.011 & 1.931 & 1.838 & 0.171 \\
& $(1.042)$ & $(0.999)$ & & $(0.904)$ & $(0.99)$ & \\
6 & 1.834 & 1.647 & 0.02 & 2.033 & 1.96 & 0.287 \\
& $(1.074)$ & $(1.037)$ & & $(0.932)$ & $(0.99)$ & \\
7 & 1.909 & 1.716 & 0.017 & 2.138 & 2.079 & 0.394 \\
& $(1.083)$ & $(1.065)$ & & $(0.943)$ & $(0.993)$ & \\
& 1.965 & 1.764 & 0.015 & 2.227 & 2.17 & 0.422 \\
9 & $(1.101)$ & $(1.077)$ & & $(0.967)$ & $(1.007)$ & \\
& 2.009 & 1.805 & 0.015 & 2.312 & 2.238 & 0.3 \\
\multirow{4}{*}{10} & $(1.122)$ & $(1.099)$ & & $(0.978)$ & $(1.025)$ & \\
& 2.056 & 1.843 & 0.013 & 2.395 & 2.304 & 0.221 \\
& $(1.139)$ & $(1.118)$ & & $(0.988)$ & $(1.052)$ &
\end{tabular}

Panel C: pre-birth non-serious sentence convictions

\begin{tabular}{lcccccc} 
pre-birth & 0.903 & 0.895 & 0.718 & 0.893 & 0.898 & 0.841 \\
& $(0.318)$ & $(0.319)$ & & $(0.287)$ & $(0.312)$ & \\
1 & 0.289 & 0.274 & 0.702 & 0.474 & 0.449 & 0.63 \\
2 & $(0.522)$ & $(0.522)$ & & $(0.647)$ & $(0.634)$ & \\
& 0.506 & 0.463 & 0.39 & 0.828 & 0.773 & 0.379 \\
3 & $(0.678)$ & $(0.674)$ & & $(0.786)$ & $(0.776)$ & \\
& 0.663 & 0.63 & 0.571 & 1.035 & 0.957 & 0.249 \\
4 & $(0.799)$ & $(0.786)$ & & $(0.851)$ & $(0.848)$ & \\
& 0.778 & 0.75 & 0.66 & 1.171 & 1.121 & 0.492 \\
5 & $(0.869)$ & $(0.856)$ & & $(0.899)$ & $(0.904)$ & \\
& 0.869 & 0.818 & 0.438 & 1.25 & 1.247 & 0.966 \\
6 & $(0.916)$ & $(0.9)$ & & $(0.943)$ & $(0.939)$ & \\
& 0.937 & 0.894 & 0.529 & 1.341 & 1.347 & 0.94 \\
7 & $(0.952)$ & $(0.926)$ & & $(0.963)$ & $(0.955)$ & \\
& 0.993 & 0.938 & 0.439 & 1.432 & 1.42 & 0.878 \\
8 & $(0.972)$ & $(0.946)$ & & $(0.989)$ & $(0.977)$ & \\
& 1.028 & 0.981 & 0.51 & 1.506 & 1.479 & 0.737 \\
& $(0.988)$ & $(0.972)$ & & $(1.027)$ & $(0.987)$ & \\
\hline
\end{tabular}

Continued on next page 
Table A.3 - continued from previous page

\begin{tabular}{|c|c|c|c|c|c|c|}
\hline \multirow[t]{2}{*}{ Years to birth } & \multicolumn{3}{|c|}{ NZ European } & \multicolumn{3}{|c|}{ Māori } \\
\hline & $\begin{array}{c}\text { daughter } \\
\text { (1) }\end{array}$ & $\begin{array}{l}\text { son } \\
(2)\end{array}$ & $\begin{array}{c}p \text {-value } \\
(3)\end{array}$ & $\begin{array}{c}\text { daughter } \\
(4)\end{array}$ & $\begin{array}{l}\text { son } \\
(5)\end{array}$ & $\begin{array}{c}p \text {-value } \\
(6)\end{array}$ \\
\hline 9 & $\begin{array}{c}1.064 \\
(1.017)\end{array}$ & $\begin{array}{c}1.022 \\
(0.989)\end{array}$ & 0.578 & $\begin{array}{c}1.572 \\
(1.055)\end{array}$ & $\begin{array}{c}1.536 \\
(1.005)\end{array}$ & 0.665 \\
\hline 10 & $\begin{array}{c}1.103 \\
(1.025)\end{array}$ & $\begin{array}{c}1.042 \\
(1.009)\end{array}$ & 0.421 & $\begin{array}{l}1.617 \\
(1.07)\end{array}$ & $\begin{array}{c}1.583 \\
(1.034)\end{array}$ & 0.684 \\
\hline \multicolumn{7}{|c|}{ Panel D: no conviction before birth } \\
\hline 1 & $\begin{array}{c}0.114 \\
(0.348)\end{array}$ & $\begin{array}{c}0.101 \\
(0.319)\end{array}$ & 0.278 & $\begin{array}{c}0.209 \\
(0.484)\end{array}$ & $\begin{array}{c}0.203 \\
(0.455)\end{array}$ & 0.77 \\
\hline 2 & $\begin{array}{c}0.208 \\
(0.492)\end{array}$ & $\begin{array}{c}0.185 \\
(0.452)\end{array}$ & 0.182 & $\begin{array}{c}0.345 \\
(0.632)\end{array}$ & $\begin{array}{c}0.36 \\
(0.593)\end{array}$ & 0.556 \\
\hline 3 & $\begin{array}{c}0.279 \\
(0.576)\end{array}$ & $\begin{array}{c}0.256 \\
(0.546)\end{array}$ & 0.277 & $\begin{array}{c}0.461 \\
(0.722)\end{array}$ & $\begin{array}{c}0.476 \\
(0.695)\end{array}$ & 0.618 \\
\hline 4 & $\begin{array}{c}0.322 \\
(0.633)\end{array}$ & $\begin{array}{c}0.303 \\
(0.597)\end{array}$ & 0.399 & $\begin{array}{l}0.553 \\
(0.79)\end{array}$ & $\begin{array}{l}0.559 \\
(0.75)\end{array}$ & 0.855 \\
\hline 5 & $\begin{array}{c}0.366 \\
(0.683)\end{array}$ & $\begin{array}{c}0.343 \\
(0.636)\end{array}$ & 0.356 & $\begin{array}{c}0.63 \\
(0.847)\end{array}$ & $\begin{array}{c}0.638 \\
(0.811)\end{array}$ & 0.82 \\
\hline 6 & $\begin{array}{c}0.397 \\
(0.719)\end{array}$ & $\begin{array}{c}0.377 \\
(0.669)\end{array}$ & 0.436 & $\begin{array}{c}0.683 \\
(0.888)\end{array}$ & $\begin{array}{c}0.71 \\
(0.864)\end{array}$ & 0.465 \\
\hline 7 & $\begin{array}{c}0.419 \\
(0.746)\end{array}$ & $\begin{array}{c}0.406 \\
(0.693)\end{array}$ & 0.606 & $\begin{array}{c}0.726 \\
(0.917)\end{array}$ & $\begin{array}{c}0.766 \\
(0.897)\end{array}$ & 0.311 \\
\hline 8 & $\begin{array}{c}0.442 \\
(0.769)\end{array}$ & $\begin{array}{c}0.429 \\
(0.719)\end{array}$ & 0.644 & $\begin{array}{l}0.764 \\
(0.94)\end{array}$ & $\begin{array}{c}0.813 \\
(0.927)\end{array}$ & 0.222 \\
\hline 9 & $\begin{array}{c}0.459 \\
(0.788)\end{array}$ & $\begin{array}{c}0.448 \\
(0.743)\end{array}$ & 0.714 & $\begin{array}{c}0.805 \\
(0.962)\end{array}$ & $\begin{array}{c}0.853 \\
(0.95)\end{array}$ & 0.248 \\
\hline 10 & $\begin{array}{c}0.477 \\
(0.805)\end{array}$ & $\begin{array}{l}0.464 \\
(0.76)\end{array}$ & 0.638 & $\begin{array}{c}0.847 \\
(0.992)\end{array}$ & $\begin{array}{c}0.888 \\
(0.974)\end{array}$ & 0.333 \\
\hline Observations & 44 & & & 368 & & \\
\hline
\end{tabular}

Notes: The table shows log-transformed accumulated numbers of convictions $(+1)$ for individuals who fathers a girl (columns (1) and (4)) and who father a boy (column (2) and (5)), differentiated by ethnic group. The $p$-values in columns (3) and (6) corresponds to a standard $t$-test. Panel A to $\mathrm{D}$ differentiate by pre-birth convictions. Panel A refers to individuals with at least one conviction before birth. Panel B refers to individuals with at least one serious conviction before birth. Panel C refers to individuals with at least one non-serious conviction before birth. Panel D refers to individuals with no conviction before birth. Standard errors in parentheses. Significance level: $* * * \mathrm{p}<0.01,{ }^{* *} \mathrm{p}<0.05, * \mathrm{p}<0.1$. 
Table A.4: The effect of child gender on father's crime (pooled sample)

\begin{tabular}{|c|c|c|c|c|c|c|c|c|}
\hline \multirow{3}{*}{$\begin{array}{l}\text { Years } \\
\text { to } \\
\text { birth }\end{array}$} & \multicolumn{4}{|c|}{ Pooled sample } & \multicolumn{4}{|c|}{ Convicted before birth } \\
\hline & \multicolumn{2}{|c|}{ total } & \multicolumn{2}{|c|}{ serious } & \multicolumn{2}{|c|}{ total } & \multicolumn{2}{|c|}{ serious } \\
\hline & $\begin{array}{c}\operatorname{count}^{\dagger} \\
(1)\end{array}$ & $\begin{array}{l}\text { binary }{ }^{\ddagger} \\
(2)\end{array}$ & $\begin{array}{c}\operatorname{count}^{\dagger} \\
(3)\end{array}$ & $\begin{array}{c}\text { binary }^{\ddagger} \\
(4)\end{array}$ & $\begin{array}{c}\operatorname{count}^{\dagger} \\
(5)\end{array}$ & $\begin{array}{c}\text { binary }^{\ddagger} \\
(6)\end{array}$ & $\begin{array}{c}\text { count }^{\dagger} \\
(7)\end{array}$ & $\begin{array}{c}\text { binary }^{\ddagger} \\
(8)\end{array}$ \\
\hline $\begin{array}{l}\text { pre- } \\
\text { birth }\end{array}$ & $\begin{array}{c}-0.006 \\
(0.016)\end{array}$ & $\begin{array}{c}0.001 \\
(0.011)\end{array}$ & $\begin{array}{l}-0.011 \\
(0.013)\end{array}$ & $\begin{array}{l}-0.009 \\
(0.009)\end{array}$ & $\begin{array}{l}-0.023 \\
(0.022)\end{array}$ & - & $\begin{array}{c}-0.033 \\
(0.03)\end{array}$ & $\begin{array}{c}-0.026 \\
(0.019)\end{array}$ \\
\hline 1 & $\begin{array}{c}-0.030^{* * *} \\
(0.012)\end{array}$ & $\begin{array}{l}-0.015^{*} \\
(0.009)\end{array}$ & $\begin{array}{c}-0.024^{* *} \\
(0.01)\end{array}$ & $\begin{array}{l}-0.011 \\
(0.007)\end{array}$ & $\begin{array}{c}-0.053^{* *} \\
(0.025)\end{array}$ & $\begin{array}{c}-0.041^{* *} \\
(0.018)\end{array}$ & $\begin{array}{l}-0.028 \\
(0.023)\end{array}$ & $\begin{array}{l}-0.013 \\
(0.016)\end{array}$ \\
\hline 2 & $\begin{array}{c}-0.041^{* * *} \\
(0.014)\end{array}$ & $\begin{array}{r}-0.011 \\
(0.01)\end{array}$ & $\begin{array}{c}-0.038^{* * *} \\
(0.013)\end{array}$ & $\begin{array}{l}-0.014 \\
(0.008)\end{array}$ & $\begin{array}{c}-0.086^{* * *} \\
(0.03)\end{array}$ & $\begin{array}{c}-0.046^{* * *} \\
(0.017)\end{array}$ & $\begin{array}{c}-0.059^{* *} \\
(0.029)\end{array}$ & $\begin{array}{l}-0.03 \\
(0.017)\end{array}$ \\
\hline 3 & $\begin{array}{c}-0.043^{* * *} \\
(0.016)\end{array}$ & $\begin{array}{l}-0.012 \\
(0.01)\end{array}$ & $\begin{array}{c}-0.042^{* * *} \\
(0.015)\end{array}$ & $\begin{array}{l}-0.015^{*} \\
(0.009)\end{array}$ & $\begin{array}{c}-0.092^{* * *} \\
(0.032)\end{array}$ & $\begin{array}{c}-0.034^{* *} \\
(0.016)\end{array}$ & $\begin{array}{c}-0.079^{* *} \\
(0.032)\end{array}$ & $\begin{array}{l}-0.037 \\
(0.017)\end{array}$ \\
\hline 4 & $\begin{array}{c}-0.044^{* *} \\
(0.017)\end{array}$ & $\begin{array}{r}-0.008 \\
(0.01)\end{array}$ & $\begin{array}{c}-0.049^{* * *} \\
(0.016)\end{array}$ & $\begin{array}{c}-0.016^{*} \\
(0.009)\end{array}$ & $\begin{array}{c}-0.088^{* * *} \\
(0.034)\end{array}$ & $\begin{array}{c}-0.033^{* *} \\
(0.015)\end{array}$ & $\begin{array}{c}-0.076^{* *} \\
(0.034)\end{array}$ & $\begin{array}{c}-0.02 \\
(0.017)\end{array}$ \\
\hline 5 & $\begin{array}{c}-0.043^{* *} \\
(0.018)\end{array}$ & $\begin{array}{l}-0.005 \\
(0.01)\end{array}$ & $\begin{array}{c}-0.051^{* * *} \\
(0.017)\end{array}$ & $\begin{array}{l}-0.015 \\
(0.009)\end{array}$ & $\begin{array}{c}-0.085^{* *} \\
(0.035)\end{array}$ & $\begin{array}{c}-0.028^{*} \\
(0.015)\end{array}$ & $\begin{array}{c}-0.075^{* *} \\
(0.035)\end{array}$ & $\begin{array}{c}-0.02 \\
(0.017)\end{array}$ \\
\hline 6 & $\begin{array}{c}-0.033^{*} \\
(0.019)\end{array}$ & $\begin{array}{l}0.001 \\
(0.01)\end{array}$ & $\begin{array}{c}-0.045^{* *} \\
(0.018)\end{array}$ & $\begin{array}{l}-0.007 \\
(0.01)\end{array}$ & $\begin{array}{c}-0.074^{* *} \\
(0.036)\end{array}$ & $\begin{array}{l}-0.020 \\
(0.015)\end{array}$ & $\begin{array}{c}-0.066^{*} \\
(0.037)\end{array}$ & $\begin{array}{l}-0.009 \\
(0.017)\end{array}$ \\
\hline 7 & $\begin{array}{l}-0.030 \\
(0.02)\end{array}$ & $\begin{array}{l}0.006 \\
(0.01)\end{array}$ & $\begin{array}{c}-0.049^{* * *} \\
(0.019)\end{array}$ & $\begin{array}{l}-0.012 \\
(0.01)\end{array}$ & $\begin{array}{c}-0.081^{* *} \\
(0.036)\end{array}$ & $\begin{array}{l}-0.023 \\
(0.014)\end{array}$ & $\begin{array}{c}-0.081^{* *} \\
(0.038)\end{array}$ & $\begin{array}{l}-0.023 \\
(0.017)\end{array}$ \\
\hline 8 & $\begin{array}{l}-0.028 \\
(0.02)\end{array}$ & $\begin{array}{l}0.007 \\
(0.01)\end{array}$ & $\begin{array}{c}-0.047^{* *} \\
(0.019)\end{array}$ & $\begin{array}{l}-0.009 \\
(0.01)\end{array}$ & $\begin{array}{c}-0.083^{* *} \\
(0.037)\end{array}$ & $\begin{array}{l}-0.018 \\
(0.014)\end{array}$ & $\begin{array}{c}-0.088^{* *} \\
(0.039)\end{array}$ & $\begin{array}{l}-0.021 \\
(0.016)\end{array}$ \\
\hline 9 & $\begin{array}{l}-0.029 \\
(0.021)\end{array}$ & $\begin{array}{l}0.006 \\
(0.01)\end{array}$ & $\begin{array}{c}-0.046^{* *} \\
(0.02)\end{array}$ & $\begin{array}{l}-0.006 \\
(0.01)\end{array}$ & $\begin{array}{c}-0.089^{* *} \\
(0.038)\end{array}$ & $\begin{array}{l}-0.013 \\
(0.014)\end{array}$ & $\begin{array}{c}-0.096^{* *} \\
(0.04)\end{array}$ & $\begin{array}{l}-0.021 \\
(0.016)\end{array}$ \\
\hline 10 & $\begin{array}{l}-0.036^{*} \\
(0.021)\end{array}$ & $\begin{array}{l}0.003 \\
(0.01)\end{array}$ & $\begin{array}{c}-0.049^{* *} \\
(0.02)\end{array}$ & $\begin{array}{l}-0.007 \\
(0.01)\end{array}$ & $\begin{array}{c}-0.097^{* *} \\
(0.039)\end{array}$ & $\begin{array}{l}-0.020 \\
(0.014)\end{array}$ & $\begin{array}{c}-0.098^{* *} \\
(0.041)\end{array}$ & $\begin{array}{l}-0.022 \\
(0.016)\end{array}$ \\
\hline
\end{tabular}

Notes: The table shows the child-gender related difference (boy vs. girl) based on OLS regressions of total convictions and serious convictions before and after child birth. Each coefficient corresponds to a separate regression. ${ }^{\dagger}$ Count refers to the log-transformed accumulated number of convictions $(+1)$. ${ }^{\ddagger}$ Binary refers to an indicator variable taking the value of 1 if number of convictions are above zero and 0 otherwise. Columns (1) to (4) correspond to all individuals pooling NZ Europeans and Māori. Columns (5) to (8) correspond to all individuals with any conviction before child birth and pooling NZ Europeans and Māori. The pre-birth period refers to the time period between two year and up to six months before birth, which is the time when the gender of the child can first be identified. Robust standard errors in parentheses, significance level: ${ }^{* * *} \mathrm{p}<0.01,{ }^{* *} \mathrm{p}<0.05,{ }^{*} \mathrm{p}<0.1$. 
Table A.5: The effect of child gender on father's crime (full sample)

\begin{tabular}{|c|c|c|c|c|c|c|c|c|}
\hline \multirow{3}{*}{$\begin{array}{l}\text { Years } \\
\text { to } \\
\text { birth }\end{array}$} & \multicolumn{4}{|c|}{ NZ European } & \multicolumn{4}{|c|}{ Māori } \\
\hline & \multicolumn{2}{|c|}{ total } & \multicolumn{2}{|c|}{ serious } & \multicolumn{2}{|c|}{ total } & \multicolumn{2}{|c|}{ serious } \\
\hline & $\begin{array}{c}\operatorname{count}^{\dagger} \\
(1)\end{array}$ & $\begin{array}{c}\text { binary }^{\ddagger} \\
(2)\end{array}$ & $\begin{array}{c}\operatorname{count}^{\dagger} \\
(3)\end{array}$ & $\begin{array}{c}\text { binary }{ }^{\ddagger} \\
(4)\end{array}$ & $\operatorname{count}^{\dagger}$ & $\begin{array}{c}\text { binary }^{\ddagger} \\
(6)\end{array}$ & $\begin{array}{c}\operatorname{count}^{\dagger} \\
(7)\end{array}$ & $\begin{array}{c}\text { binary } \\
(8)\end{array}$ \\
\hline pre-birth & $\begin{array}{c}-0.021 \\
(0.021)\end{array}$ & $\begin{array}{l}-0.003 \\
(0.014)\end{array}$ & $\begin{array}{l}-0.019 \\
(0.017)\end{array}$ & $\begin{array}{c}-0.010 \\
(0.011)\end{array}$ & $\begin{array}{c}0.013 \\
(0.023)\end{array}$ & $\begin{array}{c}0.006 \\
(0.016)\end{array}$ & $\begin{array}{l}0.001 \\
(0.02)\end{array}$ & $\begin{array}{l}-0.007 \\
(0.014)\end{array}$ \\
\hline 1 & $\begin{array}{c}-0.044^{* * *} \\
(0.014)\end{array}$ & $\begin{array}{c}-0.021^{*} \\
(0.011)\end{array}$ & $\begin{array}{c}-0.043^{* * *} \\
(0.012)\end{array}$ & $\begin{array}{c}-0.024^{* * *} \\
(0.009)\end{array}$ & $\begin{array}{l}-0.012 \\
(0.019)\end{array}$ & $\begin{array}{l}-0.007 \\
(0.014)\end{array}$ & $\begin{array}{c}0.001 \\
(0.017)\end{array}$ & $\begin{array}{c}0.006 \\
(0.012)\end{array}$ \\
\hline 2 & $\begin{array}{c}-0.059 * * * \\
(0.018)\end{array}$ & $\begin{array}{c}-0.028^{* *} \\
(0.012)\end{array}$ & $\begin{array}{c}-0.054^{* * * *} \\
(0.015)\end{array}$ & $\begin{array}{c}-0.023^{* *} \\
(0.01)\end{array}$ & $\begin{array}{l}-0.017 \\
(0.023)\end{array}$ & $\begin{array}{c}0.009 \\
(0.015)\end{array}$ & $\begin{array}{l}-0.016 \\
(0.021)\end{array}$ & $\begin{array}{l}-0.001 \\
(0.014)\end{array}$ \\
\hline 3 & $\begin{array}{c}-0.053^{* * *} \\
(0.02)\end{array}$ & $\begin{array}{l}-0.018 \\
(0.013)\end{array}$ & $\begin{array}{c}-0.059 * * * \\
(0.018)\end{array}$ & $\begin{array}{c}-0.029^{* * * *} \\
(0.011)\end{array}$ & $\begin{array}{l}-0.029 \\
(0.026)\end{array}$ & $\begin{array}{l}-0.003 \\
(0.015)\end{array}$ & $\begin{array}{l}-0.018 \\
(0.024)\end{array}$ & $\begin{array}{c}0.004 \\
(0.014)\end{array}$ \\
\hline 4 & $\begin{array}{c}-0.051^{* *} \\
(0.022)\end{array}$ & $\begin{array}{l}-0.009 \\
(0.013)\end{array}$ & $\begin{array}{c}-0.065^{* * *} \\
(0.019)\end{array}$ & $\begin{array}{c}-0.029^{* *} \\
(0.011)\end{array}$ & $\begin{array}{l}-0.031 \\
(0.027)\end{array}$ & $\begin{array}{l}-0.004 \\
(0.015)\end{array}$ & $\begin{array}{l}-0.027 \\
(0.026)\end{array}$ & $\begin{array}{c}0.003 \\
(0.015)\end{array}$ \\
\hline 5 & $\begin{array}{c}-0.055^{* *} \\
(0.023)\end{array}$ & $\begin{array}{l}-0.008 \\
(0.013)\end{array}$ & $\begin{array}{c}-0.072^{* * *} \\
(0.021)\end{array}$ & $\begin{array}{c}-0.029^{* *} \\
(0.012)\end{array}$ & $\begin{array}{l}-0.025 \\
(0.029)\end{array}$ & $\begin{array}{c}0.002 \\
(0.015)\end{array}$ & $\begin{array}{l}-0.022 \\
(0.028)\end{array}$ & $\begin{array}{c}0.006 \\
(0.015)\end{array}$ \\
\hline 6 & $\begin{array}{c}-0.051^{* *} \\
(0.024)\end{array}$ & $\begin{array}{l}-0.003 \\
(0.014)\end{array}$ & $\begin{array}{c}-0.071^{* * *} \\
(0.022)\end{array}$ & $\begin{array}{c}-0.023^{*} \\
(0.012)\end{array}$ & $\begin{array}{l}-0.008 \\
(0.03)\end{array}$ & $\begin{array}{c}0.009 \\
(0.015)\end{array}$ & $\begin{array}{l}-0.010 \\
(0.029)\end{array}$ & $\begin{array}{c}0.015 \\
(0.015)\end{array}$ \\
\hline 7 & $\begin{array}{c}-0.049^{* *} \\
(0.025)\end{array}$ & $\begin{array}{c}0.001 \\
(0.014)\end{array}$ & $\begin{array}{c}-0.077^{* * *} \\
(0.022)\end{array}$ & $\begin{array}{c}-0.026^{* *} \\
(0.012)\end{array}$ & $\begin{array}{l}-0.003 \\
(0.031)\end{array}$ & $\begin{array}{l}0.015 \\
(0.015)\end{array}$ & $\begin{array}{c}-0.010 \\
(0.03)\end{array}$ & $\begin{array}{c}0.009 \\
(0.015)\end{array}$ \\
\hline 8 & $\begin{array}{c}-0.047^{*} \\
(0.025)\end{array}$ & $\begin{array}{c}0.000 \\
(0.014)\end{array}$ & $\begin{array}{c}-0.078^{* * *} * \\
(0.023)\end{array}$ & $\begin{array}{c}-0.029^{* *} \\
(0.012)\end{array}$ & $\begin{array}{c}0.001 \\
(0.032)\end{array}$ & $\begin{array}{l}0.019 \\
(0.015)\end{array}$ & $\begin{array}{l}-0.005 \\
(0.031)\end{array}$ & $\begin{array}{c}0.019 \\
(0.015)\end{array}$ \\
\hline 9 & $\begin{array}{c}-0.045^{*} \\
(0.026)\end{array}$ & $\begin{array}{c}0.001 \\
(0.014)\end{array}$ & $\begin{array}{c}-0.075^{* * *} \\
(0.024)\end{array}$ & $\begin{array}{c}-0.024^{* *} \\
(0.012)\end{array}$ & $\begin{array}{l}-0.006 \\
(0.032)\end{array}$ & $\begin{array}{c}0.015 \\
(0.015)\end{array}$ & $\begin{array}{l}-0.009 \\
(0.032)\end{array}$ & $\begin{array}{c}0.018 \\
(0.015)\end{array}$ \\
\hline 10 & $\begin{array}{c}-0.052^{* *} \\
(0.026)\end{array}$ & $\begin{array}{l}-0.003 \\
(0.014)\end{array}$ & $\begin{array}{c}-0.076^{* * *} \\
(0.024)\end{array}$ & $\begin{array}{c}-0.024^{*} \\
(0.013)\end{array}$ & $\begin{array}{l}-0.011 \\
(0.033)\end{array}$ & $\begin{array}{c}0.013 \\
(0.015)\end{array}$ & $\begin{array}{l}-0.012 \\
(0.033)\end{array}$ & $\begin{array}{c}0.016 \\
(0.015)\end{array}$ \\
\hline$N$ & & & & & & & & \\
\hline
\end{tabular}

Notes: The table shows the child-gender related difference (boy vs. girl) based on OLS regressions of total convictions and serious convictions before and after child birth. Each coefficient corresponds to a separate regression. ${ }^{\dagger}$ Count refers to the log-transformed accumulated number of convictions $(+1)$. ${ }^{\ddagger}$ Binary refers to an indicator variable taking the value of 1 if number of convictions are above zero and 0 otherwise. Columns (1) to (4) correspond to all NZ Europeans. Columns (5) to (8) correspond to all Māori. The pre-birth period refers to the time period between two year and up to six months before birth, which is the time when the gender of the child can first be identified. Robust standard errors in parentheses, significance level: ${ }^{* * *} \mathrm{p}<0.01,{ }^{*} * \mathrm{p}<0.05,{ }^{*} \mathrm{p}<0.1$. 
Table A.6: The effect of child gender on father's crime (any conviction before birth)

\begin{tabular}{|c|c|c|c|c|c|c|c|c|}
\hline \multirow{3}{*}{$\begin{array}{l}\text { Years } \\
\text { to } \\
\text { birth }\end{array}$} & \multicolumn{4}{|c|}{ NZ European } & \multicolumn{4}{|c|}{ Māori } \\
\hline & \multicolumn{2}{|c|}{ total } & \multicolumn{2}{|c|}{ serious } & \multicolumn{2}{|c|}{ total } & \multicolumn{2}{|c|}{ serious } \\
\hline & $\begin{array}{c}\text { count }^{\dagger} \\
(1)\end{array}$ & $\begin{array}{l}\text { binary } \ddagger \\
(2)\end{array}$ & $\begin{array}{c}\operatorname{count}^{\dagger} \\
(3)\end{array}$ & $\begin{array}{c}\text { binary }{ }^{\ddagger} \\
(4)\end{array}$ & $\begin{array}{c}\text { count }^{\dagger} \\
(5)\end{array}$ & $\begin{array}{l}\text { binary }{ }^{\ddagger} \\
(6)\end{array}$ & $\begin{array}{c}\operatorname{count}^{\dagger} \\
(7)\end{array}$ & $\begin{array}{c}\text { binary } \\
(8)\end{array}$ \\
\hline $\begin{array}{l}\text { pre- } \\
\text { birth }\end{array}$ & $\begin{array}{l}-0.048 \\
(0.032)\end{array}$ & - & $\begin{array}{l}-0.045 \\
(0.043)\end{array}$ & $\begin{array}{c}-0.021 \\
(0.026)\end{array}$ & $\begin{array}{l}0.007 \\
(0.03)\end{array}$ & - & $\begin{array}{l}-0.014 \\
(0.042)\end{array}$ & $\begin{array}{l}-0.028 \\
(0.026)\end{array}$ \\
\hline 1 & $\begin{array}{c}-0.089^{* * *} \\
(0.033)\end{array}$ & $\begin{array}{c}-0.050^{* *} \\
(0.024)\end{array}$ & $\begin{array}{c}-0.082^{* * *} \\
(0.03)\end{array}$ & $\begin{array}{c}-0.045^{* *} \\
(0.022)\end{array}$ & $\begin{array}{l}-0.016 \\
(0.038)\end{array}$ & $\begin{array}{l}-0.029 \\
(0.025)\end{array}$ & $\begin{array}{c}0.027 \\
(0.036)\end{array}$ & $\begin{array}{c}0.022 \\
(0.025)\end{array}$ \\
\hline 2 & $\begin{array}{c}-0.117^{* * *} \\
(0.04)\end{array}$ & $\begin{array}{c}-0.054^{* *} \\
(0.024)\end{array}$ & $\begin{array}{c}-0.102^{* * *} \\
(0.038)\end{array}$ & $\begin{array}{c}-0.044^{*} \\
(0.024)\end{array}$ & $\begin{array}{l}-0.050 \\
(0.043)\end{array}$ & $\begin{array}{l}-0.035 \\
(0.023)\end{array}$ & $\begin{array}{l}-0.012 \\
(0.043)\end{array}$ & $\begin{array}{l}-0.015 \\
(0.025)\end{array}$ \\
\hline 3 & $\begin{array}{c}-0.099^{* *} \\
(0.044)\end{array}$ & $\begin{array}{c}-0.021 \\
(0.024)\end{array}$ & $\begin{array}{c}-0.116^{* * *} \\
(0.042)\end{array}$ & $\begin{array}{c}-0.055^{* *} \\
(0.024)\end{array}$ & $\begin{array}{l}-0.078^{*} \\
(0.046)\end{array}$ & $\begin{array}{c}-0.044^{* *} \\
(0.021)\end{array}$ & $\begin{array}{l}-0.036 \\
(0.047)\end{array}$ & $\begin{array}{l}-0.017 \\
(0.024)\end{array}$ \\
\hline 4 & $\begin{array}{c}-0.105^{* *} \\
(0.046)\end{array}$ & $\begin{array}{l}-0.025 \\
(0.023)\end{array}$ & $\begin{array}{c}-0.116^{* *} \\
(0.045)\end{array}$ & $\begin{array}{l}-0.037 \\
(0.024)\end{array}$ & $\begin{array}{l}-0.066 \\
(0.048)\end{array}$ & $\begin{array}{c}-0.040^{* *} \\
(0.02)\end{array}$ & $\begin{array}{l}-0.030 \\
(0.05)\end{array}$ & $\begin{array}{l}-0.003 \\
(0.024)\end{array}$ \\
\hline 5 & $\begin{array}{c}-0.112^{* *} \\
(0.049)\end{array}$ & $\begin{array}{l}-0.028 \\
(0.023)\end{array}$ & $\begin{array}{c}-0.128^{* * *} \\
(0.048)\end{array}$ & $\begin{array}{l}-0.042^{*} \\
(0.024)\end{array}$ & $\begin{array}{l}-0.052 \\
(0.048)\end{array}$ & $\begin{array}{l}-0.026 \\
(0.018)\end{array}$ & $\begin{array}{l}-0.018 \\
(0.051)\end{array}$ & $\begin{array}{c}0.003 \\
(0.023)\end{array}$ \\
\hline 6 & $\begin{array}{c}-0.105^{* *} \\
(0.05)\end{array}$ & $\begin{array}{l}-0.019 \\
(0.022)\end{array}$ & $\begin{array}{c}-0.117^{* *} \\
(0.05)\end{array}$ & $\begin{array}{l}-0.029 \\
(0.024)\end{array}$ & $\begin{array}{l}-0.037 \\
(0.049)\end{array}$ & $\begin{array}{l}-0.020 \\
(0.018)\end{array}$ & $\begin{array}{l}-0.010 \\
(0.052)\end{array}$ & $\begin{array}{c}0.011 \\
(0.022)\end{array}$ \\
\hline 7 & $\begin{array}{c}-0.114^{* *} \\
(0.051)\end{array}$ & $\begin{array}{l}-0.027 \\
(0.022)\end{array}$ & $\begin{array}{c}-0.131^{* *} \\
(0.051)\end{array}$ & $\begin{array}{l}-0.042^{*} \\
(0.024)\end{array}$ & $\begin{array}{l}-0.040 \\
(0.05)\end{array}$ & $\begin{array}{l}-0.018 \\
(0.017)\end{array}$ & $\begin{array}{l}-0.023 \\
(0.054)\end{array}$ & $\begin{array}{l}-0.002 \\
(0.022)\end{array}$ \\
\hline 8 & $\begin{array}{c}-0.113^{* *} \\
(0.052)\end{array}$ & $\begin{array}{l}-0.027 \\
(0.022)\end{array}$ & $\begin{array}{c}-0.135^{* * *} \\
(0.052)\end{array}$ & $\begin{array}{l}-0.046^{*} \\
(0.024)\end{array}$ & $\begin{array}{l}-0.046 \\
(0.052)\end{array}$ & $\begin{array}{l}-0.009 \\
(0.017)\end{array}$ & $\begin{array}{l}-0.031 \\
(0.055)\end{array}$ & $\begin{array}{c}0.007 \\
(0.022)\end{array}$ \\
\hline 9 & $\begin{array}{c}-0.114^{* *} \\
(0.053)\end{array}$ & $\begin{array}{l}-0.019 \\
(0.022)\end{array}$ & $\begin{array}{c}-0.140^{* * *} \\
(0.054)\end{array}$ & $\begin{array}{l}-0.045^{*} \\
(0.024)\end{array}$ & $\begin{array}{l}-0.059 \\
(0.053)\end{array}$ & $\begin{array}{l}-0.008 \\
(0.016)\end{array}$ & $\begin{array}{l}-0.046 \\
(0.056)\end{array}$ & $\begin{array}{c}0.003 \\
(0.021)\end{array}$ \\
\hline 10 & $\begin{array}{c}-0.129^{* *} \\
(0.054)\end{array}$ & $\begin{array}{l}-0.028 \\
(0.022)\end{array}$ & $\begin{array}{c}-0.146^{* * *} \\
(0.055)\end{array}$ & $\begin{array}{l}-0.045^{*} \\
(0.024)\end{array}$ & $\begin{array}{l}-0.064 \\
(0.054)\end{array}$ & $\begin{array}{l}-0.013 \\
(0.016)\end{array}$ & $\begin{array}{l}-0.048 \\
(0.058)\end{array}$ & $\begin{array}{c}0 \\
(0.021)\end{array}$ \\
\hline
\end{tabular}

N 1473

1443

Notes: The table shows the child-gender related difference (boy vs. girl) based on OLS regressions of total convictions and serious convictions before and after child birth. Each coefficient corresponds to a separate regression. ${ }^{\dagger}$ Count refers to the log-transformed accumulated number of convictions $(+1)$. ${ }^{\ddagger}$ Binary refers to an indicator variable taking the value of 1 if number of convictions are above zero and 0 otherwise. Columns (1) to (4) correspond to all NZ Europeans with at least one pre-birth conviction of any type. Columns (5) to (8) correspond to all Māori with at least one pre-birth conviction of any type. The pre-birth period refers to the time period between two year and up to six months before birth, which is the time when the gender of the child can first be identified. Robust standard errors in parentheses, significance level: ${ }^{* * *} \mathrm{p}<0.01,{ }^{*} * \mathrm{p}<0.05,{ }^{*} \mathrm{p}<0.1$. 
Table A.7: The effect of child gender on father's crime (serious conviction before birth)

\begin{tabular}{|c|c|c|c|c|c|c|c|c|}
\hline \multirow{3}{*}{$\begin{array}{l}\text { Years } \\
\text { to } \\
\text { birth }\end{array}$} & \multicolumn{4}{|c|}{ NZ European } & \multicolumn{4}{|c|}{ Māori } \\
\hline & \multicolumn{2}{|c|}{ total } & \multicolumn{2}{|c|}{ serious } & \multicolumn{2}{|c|}{ total } & \multicolumn{2}{|c|}{ serious } \\
\hline & $\begin{array}{c}\operatorname{count}^{\dagger} \\
(1)\end{array}$ & $\begin{array}{c}\text { binary }{ }^{\ddagger} \\
(2)\end{array}$ & $\begin{array}{c}\text { count }^{\dagger} \\
(3)\end{array}$ & $\begin{array}{c}\text { binary }^{\ddagger} \\
(4)\end{array}$ & $\begin{array}{c}\operatorname{count}^{\dagger} \\
(5)\end{array}$ & $\begin{array}{c}\text { binary }^{\ddagger} \\
(6)\end{array}$ & $\begin{array}{c}\operatorname{count}^{\dagger} \\
(7)\end{array}$ & $\begin{array}{c}\text { binary } \\
(8)\end{array}$ \\
\hline $\begin{array}{l}\text { pre- } \\
\text { birth }\end{array}$ & & - & & - & & - & & - \\
\hline 1 & $\begin{array}{c}-0.192^{* * *} \\
(0.055)\end{array}$ & $\begin{array}{c}-0.093^{* * *} \\
(0.036)\end{array}$ & $\begin{array}{c}-0.179^{* * *} \\
(0.053)\end{array}$ & $\begin{array}{c}-0.088^{* *} \\
(0.036)\end{array}$ & $\begin{array}{l}-0.002 \\
(0.055)\end{array}$ & $\begin{array}{l}-0.036 \\
(0.034)\end{array}$ & $\begin{array}{c}0.045 \\
(0.054)\end{array}$ & $\begin{array}{c}0.03 \\
(0.034)\end{array}$ \\
\hline 2 & $\begin{array}{c}-0.224^{* * *} \\
(0.064)\end{array}$ & $\begin{array}{c}-0.095^{* * *} \\
(0.032)\end{array}$ & $\begin{array}{c}-0.221^{* * *} \\
(0.064)\end{array}$ & $\begin{array}{c}-0.095^{* * *} \\
(0.036)\end{array}$ & $\begin{array}{l}-0.045 \\
(0.061)\end{array}$ & $\begin{array}{c}-0.047^{*} \\
(0.028)\end{array}$ & $\begin{array}{c}0.002 \\
(0.061)\end{array}$ & $\begin{array}{l}-0.005 \\
(0.032)\end{array}$ \\
\hline 3 & $\begin{array}{c}-0.205^{* * *} \\
(0.067)\end{array}$ & $\begin{array}{c}-0.055^{*} \\
(0.03)\end{array}$ & $\begin{array}{c}-0.221^{* * *} \\
(0.068)\end{array}$ & $\begin{array}{c}-0.088^{* * *} \\
(0.034)\end{array}$ & $\begin{array}{l}-0.073 \\
(0.063)\end{array}$ & $\begin{array}{c}-0.054^{* *} \\
(0.024)\end{array}$ & $\begin{array}{l}-0.033 \\
(0.067)\end{array}$ & $\begin{array}{r}-0.027 \\
(0.03)\end{array}$ \\
\hline 4 & $\begin{array}{c}-0.223^{* * *} \\
(0.069)\end{array}$ & $\begin{array}{l}-0.053^{*} \\
(0.027)\end{array}$ & $\begin{array}{c}-0.235^{* * *} \\
(0.071)\end{array}$ & $\begin{array}{c}-0.066^{* *} \\
(0.032)\end{array}$ & $\begin{array}{l}-0.076 \\
(0.064)\end{array}$ & $\begin{array}{c}-0.049^{* *} \\
(0.021)\end{array}$ & $\begin{array}{l}-0.041 \\
(0.069)\end{array}$ & $\begin{array}{c}-0.02 \\
(0.028)\end{array}$ \\
\hline 5 & $\begin{array}{c}-0.210^{* * *} \\
(0.071)\end{array}$ & $\begin{array}{l}-0.041 \\
(0.026)\end{array}$ & $\begin{array}{c}-0.238^{* * *} \\
(0.074)\end{array}$ & $\begin{array}{c}-0.068^{* *} \\
(0.031)\end{array}$ & $\begin{array}{l}-0.087 \\
(0.064)\end{array}$ & $\begin{array}{c}-0.047^{* *} \\
(0.021)\end{array}$ & $\begin{array}{l}-0.048 \\
(0.07)\end{array}$ & $\begin{array}{l}-0.007 \\
(0.026)\end{array}$ \\
\hline 6 & $\begin{array}{c}-0.207^{* * *} \\
(0.073)\end{array}$ & $\begin{array}{l}-0.037 \\
(0.025)\end{array}$ & $\begin{array}{c}-0.219^{* * *} \\
(0.076)\end{array}$ & $\begin{array}{c}-0.058^{*} \\
(0.031)\end{array}$ & $\begin{array}{l}-0.068 \\
(0.064)\end{array}$ & $\begin{array}{c}-0.034^{*} \\
(0.019)\end{array}$ & $\begin{array}{r}-0.046 \\
(0.07)\end{array}$ & $\begin{array}{c}0.005 \\
(0.025)\end{array}$ \\
\hline 7 & $\begin{array}{c}-0.219^{* * *} \\
(0.074)\end{array}$ & $\begin{array}{l}-0.047^{*} \\
(0.024)\end{array}$ & $\begin{array}{c}-0.240^{* * *} \\
(0.077)\end{array}$ & $\begin{array}{c}-0.078^{* * *} \\
(0.03)\end{array}$ & $\begin{array}{l}-0.059 \\
(0.066)\end{array}$ & $\begin{array}{l}-0.030 \\
(0.019)\end{array}$ & $\begin{array}{l}-0.048 \\
(0.072)\end{array}$ & $\begin{array}{l}-0.004 \\
(0.024)\end{array}$ \\
\hline 8 & $\begin{array}{c}-0.229^{* * *} \\
(0.075)\end{array}$ & $\begin{array}{l}-0.045^{*} \\
(0.024)\end{array}$ & $\begin{array}{c}-0.253^{* * *} \\
(0.078)\end{array}$ & $\begin{array}{c}-0.087^{* * *} \\
(0.03)\end{array}$ & $\begin{array}{l}-0.059 \\
(0.067)\end{array}$ & $\begin{array}{l}-0.026 \\
(0.018)\end{array}$ & $\begin{array}{c}-0.042 \\
(0.074)\end{array}$ & $\begin{array}{c}0 \\
(0.023)\end{array}$ \\
\hline 9 & $\begin{array}{c}-0.236^{* * *} \\
(0.076)\end{array}$ & $\begin{array}{l}-0.041^{*} \\
(0.024)\end{array}$ & $\begin{array}{c}-0.262^{* * *} \\
(0.08)\end{array}$ & $\begin{array}{c}-0.086^{* * *} \\
(0.03)\end{array}$ & $\begin{array}{l}-0.075 \\
(0.068)\end{array}$ & $\begin{array}{l}-0.025 \\
(0.017)\end{array}$ & $\begin{array}{l}-0.055 \\
(0.075)\end{array}$ & $\begin{array}{c}0.003 \\
(0.023)\end{array}$ \\
\hline 10 & $\begin{array}{c}-0.245^{* * *} \\
(0.077)\end{array}$ & $\begin{array}{c}-0.043^{*} \\
(0.023)\end{array}$ & $\begin{array}{c}-0.265^{* * *} \\
(0.081)\end{array}$ & $\begin{array}{c}-0.087^{* * *} \\
(0.03)\end{array}$ & $\begin{array}{l}-0.084 \\
(0.07)\end{array}$ & $\begin{array}{c}-0.029^{*} \\
(0.017)\end{array}$ & $\begin{array}{l}-0.063 \\
(0.077)\end{array}$ & $\begin{array}{l}-0.009 \\
(0.022)\end{array}$ \\
\hline
\end{tabular}

Notes: The table shows the child-gender related difference (boy vs. girl) based on OLS regressions of total convictions and serious convictions before and after child birth. Each coefficient corresponds to a separate regression. ${ }^{\dagger}$ Count refers to the log-transformed accumulated number of convictions $(+1)$. ${ }^{\ddagger}$ Binary refers to an indicator variable taking the value of 1 if number of convictions are above zero and 0 otherwise. Columns (1) to (4) correspond to all NZ Europeans with at least one serious pre-birth conviction. Columns (5) to (8) correspond to all Māori with at least one serious pre-birth conviction. The pre-birth period refers to the time period between two year and up to six months before birth, which is the time when the gender of the child can first be identified. Robust standard errors in parentheses, significance level: $* * * \mathrm{p}<0.01,{ }^{*} \mathrm{p}<0.05,{ }^{*} \mathrm{p}<0.1$. 
Table A.8: The effect of child gender on father's crime (non-serious conviction before birth)

\begin{tabular}{|c|c|c|c|c|c|c|c|c|}
\hline \multirow{3}{*}{$\begin{array}{l}\text { Years } \\
\text { to } \\
\text { birth }\end{array}$} & \multicolumn{4}{|c|}{ NZ European } & \multicolumn{4}{|c|}{ Māori } \\
\hline & \multicolumn{2}{|c|}{ total } & \multicolumn{2}{|c|}{ serious } & \multicolumn{2}{|c|}{ total } & \multicolumn{2}{|c|}{ serious } \\
\hline & $\begin{array}{c}\text { count }^{\dagger} \\
(1)\end{array}$ & $\begin{array}{c}\text { binary } \\
\quad(2)\end{array}$ & $\begin{array}{c}\text { count }^{\dagger} \\
(3)\end{array}$ & $\begin{array}{c}\text { binary } \\
(4)\end{array}$ & count $^{\dagger}$ & $\begin{array}{c}\text { binary } \\
(6)\end{array}$ & $\begin{array}{c}\text { count }^{\dagger} \\
(7)\end{array}$ & binary $^{\ddagger}$ \\
\hline pre- & -0.005 & - & - & - & 0.000 & - & - & - \\
\hline birth & $(0.023)$ & & & & $(0.024)$ & & & \\
\hline \multirow[t]{2}{*}{1} & 0.000 & -0.016 & 0.004 & -0.007 & -0.019 & -0.012 & 0.016 & 0.023 \\
\hline & $(0.037)$ & $(0.031)$ & $(0.03)$ & $(0.024)$ & $(0.051)$ & $(0.038)$ & $(0.044)$ & $(0.033)$ \\
\hline \multirow[t]{2}{*}{2} & -0.021 & -0.022 & 0.007 & 0.001 & -0.052 & -0.021 & -0.021 & -0.021 \\
\hline & $(0.048)$ & $(0.035)$ & $(0.04)$ & $(0.029)$ & $(0.061)$ & $(0.038)$ & $(0.057)$ & $(0.038)$ \\
\hline \multirow[t]{2}{*}{3} & -0.006 & 0.003 & -0.018 & -0.025 & -0.081 & -0.032 & -0.030 & 0.004 \\
\hline & $(0.057)$ & $(0.036)$ & $(0.049)$ & $(0.032)$ & $(0.066)$ & $(0.036)$ & $(0.065)$ & $(0.039)$ \\
\hline \multirow[t]{2}{*}{4} & 0.000 & -0.004 & -0.003 & -0.009 & -0.052 & -0.030 & -0.008 & 0.023 \\
\hline & $(0.062)$ & $(0.036)$ & $(0.056)$ & $(0.033)$ & $(0.07)$ & $(0.034)$ & $(0.07)$ & $(0.04)$ \\
\hline \multirow[t]{2}{*}{5} & -0.024 & -0.020 & -0.024 & -0.018 & -0.007 & -0.006 & 0.030 & 0.02 \\
\hline & $(0.065)$ & $(0.036)$ & $(0.06)$ & $(0.034)$ & $(0.073)$ & $(0.034)$ & $(0.074)$ & $(0.039)$ \\
\hline \multirow[t]{2}{*}{6} & -0.015 & -0.006 & -0.023 & -0.002 & 0.002 & -0.009 & 0.045 & 0.021 \\
\hline & $(0.067)$ & $(0.036)$ & $(0.063)$ & $(0.035)$ & $(0.075)$ & $(0.032)$ & $(0.077)$ & $(0.039)$ \\
\hline \multirow[t]{2}{*}{7} & -0.020 & -0.012 & -0.030 & -0.009 & -0.014 & -0.004 & 0.019 & 0.006 \\
\hline & $(0.069)$ & $(0.035)$ & $(0.065)$ & $(0.035)$ & $(0.077)$ & $(0.031)$ & $(0.08)$ & $(0.038)$ \\
\hline \multirow[t]{2}{*}{8} & -0.011 & -0.014 & -0.027 & -0.009 & -0.027 & 0.013 & -0.008 & 0.02 \\
\hline & $(0.07)$ & $(0.035)$ & $(0.067)$ & $(0.035)$ & $(0.079)$ & $(0.031)$ & $(0.082)$ & $(0.038)$ \\
\hline \multirow[t]{2}{*}{9} & -0.004 & -0.001 & -0.025 & -0.005 & -0.037 & 0.010 & -0.025 & 0.008 \\
\hline & $(0.072)$ & $(0.035)$ & $(0.07)$ & $(0.036)$ & $(0.08)$ & $(0.03)$ & $(0.084)$ & $(0.038)$ \\
\hline \multirow[t]{2}{*}{10} & -0.024 & -0.016 & -0.033 & -0.005 & -0.036 & 0.002 & -0.011 & 0.019 \\
\hline & $(0.073)$ & $(0.035)$ & $(0.071)$ & $(0.036)$ & $(0.083)$ & $(0.03)$ & $(0.087)$ & $(0.038)$ \\
\hline
\end{tabular}

Notes: The table shows the child-gender related difference (boy vs. girl) based on OLS regressions of total convictions and serious convictions before and after child birth. Each coefficient corresponds to a separate regression. ${ }^{\dagger}$ Count refers to the log-transformed accumulated number of convictions $(+1)$. ${ }^{\ddagger}$ Binary refers to an indicator variable taking the value of 1 if number of convictions are above zero and 0 otherwise. Columns (1) to (4) correspond to all NZ Europeans with at least one non-serious pre-birth conviction. Columns (5) to (8) correspond to all Māori with at least one non-serious pre-birth conviction. The pre-birth period refers to the time period between two year and up to six months before birth, which is the time when the gender of the child can first be identified. Robust standard errors in parentheses, significance level: *** $\mathrm{p}<0.01, * * \mathrm{p}<0.05, * \mathrm{p}<0.1$. 
Table A.9: The effect of child gender on father's crime (no conviction before birth)

\begin{tabular}{|c|c|c|c|c|c|c|c|c|}
\hline \multirow{3}{*}{$\begin{array}{l}\text { Years } \\
\text { to } \\
\text { birth }\end{array}$} & \multicolumn{4}{|c|}{ NZ European } & \multicolumn{4}{|c|}{ Māori } \\
\hline & \multicolumn{2}{|c|}{ total } & \multicolumn{2}{|c|}{ serious } & \multicolumn{2}{|c|}{ total } & \multicolumn{2}{|c|}{ serious } \\
\hline & $\begin{array}{c}\operatorname{count}^{\dagger} \\
(1)\end{array}$ & $\begin{array}{l}\text { binary }{ }^{\ddagger} \\
(2)\end{array}$ & $\begin{array}{c}\text { count }^{\dagger} \\
(3)\end{array}$ & $\begin{array}{l}\text { binary }{ }^{\ddagger} \\
(4)\end{array}$ & $\begin{array}{c}\operatorname{count}^{\dagger} \\
(5)\end{array}$ & $\begin{array}{l}\text { binary }{ }^{\ddagger} \\
(6)\end{array}$ & $\begin{array}{c}\operatorname{count}^{\dagger} \\
(7)\end{array}$ & $\begin{array}{c}\text { binary }^{\ddagger} \\
(8)\end{array}$ \\
\hline \multirow[t]{2}{*}{1} & -0.016 & -0.008 & $-0.018^{* *}$ & $-0.015^{* *}$ & -0.010 & 0.006 & -0.018 & -0.003 \\
\hline & $(0.012)$ & $(0.012)$ & $(0.009)$ & $(0.007$ & $(0.02)$ & $(0.017)$ & $(0.017)$ & $(0.013)$ \\
\hline \multirow[t]{2}{*}{2} & -0.028 & -0.018 & $-0.027^{* *}$ & -0.016 & 0.009 & $0.039^{* *}$ & -0.017 & 0.008 \\
\hline & $(0.017)$ & $(0.014)$ & $(0.013)$ & $(0.01)$ & $(0.026)$ & $(0.019)$ & $(0.022)$ & $(0.015)$ \\
\hline \multirow[t]{2}{*}{3} & -0.028 & -0.018 & $-0.028^{*}$ & $-0.020^{*}$ & 0.007 & 0.026 & -0.003 & 0.018 \\
\hline & $(0.021)$ & $(0.015)$ & $(0.016)$ & $(0.011)$ & $(0.03)$ & $(0.021)$ & $(0.026)$ & $(0.017)$ \\
\hline \multirow[t]{2}{*}{4} & -0.025 & -0.003 & $-0.038^{* *}$ & $-0.027^{* *}$ & -0.004 & 0.022 & -0.019 & 0.007 \\
\hline & $(0.023)$ & $(0.016)$ & $(0.018)$ & $(0.012)$ & $(0.033)$ & $(0.021)$ & $(0.028)$ & $(0.018)$ \\
\hline \multirow[t]{2}{*}{5} & -0.028 & 0.000 & $-0.044^{* *}$ & $-0.026^{* *}$ & -0.003 & 0.024 & -0.020 & 0.008 \\
\hline & $(0.024)$ & $(0.016)$ & $(0.02)$ & $(0.013)$ & $(0.035)$ & $(0.021)$ & $(0.031)$ & $(0.019)$ \\
\hline \multirow[t]{2}{*}{6} & -0.026 & 0.002 & $-0.048^{* *}$ & $-0.024^{*}$ & 0.017 & 0.032 & -0.004 & 0.018 \\
\hline & $(0.026)$ & $(0.017)$ & $(0.021)$ & $(0.013)$ & $(0.037)$ & $(0.021)$ & $(0.033)$ & $(0.02)$ \\
\hline \multirow[t]{2}{*}{7} & -0.020 & 0.013 & $-0.051^{* *}$ & $-0.023^{*}$ & 0.027 & $0.040^{*}$ & 0.004 & 0.017 \\
\hline & $(0.027)$ & $(0.017)$ & $(0.022)$ & & $(0.039)$ & $(0.021)$ & $(0.035)$ & $(0.02)$ \\
\hline \multirow[t]{2}{*}{8} & -0.019 & 0.010 & $-0.051^{* *}$ & $-0.024^{*}$ & 0.038 & $0.041^{*}$ & 0.018 & 0.028 \\
\hline & $(0.028)$ & $(0.017)$ & $(0.023)$ & & $(0.04)$ & $(0.021)$ & $(0.036)$ & $(0.02)$ \\
\hline \multirow[t]{2}{*}{9} & -0.016 & 0.007 & $-0.045^{*}$ & -0.019 & 0.035 & 0.035 & 0.021 & 0.029 \\
\hline & $(0.028)$ & $(0.017)$ & & $(0.014)$ & $(0.041)$ & $(0.021)$ & $(0.038)$ & $(0.02)$ \\
\hline \multirow[t]{2}{*}{10} & -0.020 & 0.005 & $-0.044^{*}$ & -0.019 & 0.029 & $0.035^{*}$ & 0.017 & 0.027 \\
\hline & $(0.029)$ & $(0.017)$ & $(0.024)$ & $(0.014)$ & $(0.042)$ & $(0.022)$ & $(0.039)$ & $(0.021)$ \\
\hline
\end{tabular}

Notes: The table shows the child-gender related difference (boy vs. girl) based on OLS regressions of total convictions and serious convictions before and after child birth. Each coefficient corresponds to a separate regression. ${ }^{\dagger}$ Count refers to the log-transformed accumulated number of convictions $(+1)$. ${ }^{\ddagger}$ Binary refers to an indicator variable taking the value of 1 if number of convictions are above zero and 0 otherwise. Columns (1) to (4) correspond to all NZ Europeans with no pre-birth conviction. Columns (5) to (8) correspond to all Māori with no pre-birth conviction. The pre-birth period refers to the time period between two year and up to six months before birth, which is the time when the gender of the child can first be identified. Robust standard errors in parentheses, significance level: $* * * \mathrm{p}<0.01,{ }^{* *} \mathrm{p}<0.05,{ }^{*} \mathrm{p}<0.1$. 
Table A.10: Child-gender related difference in serious conviction rates by ethnicity and pre-birth convictions, differentiated according to the 2006 Social Deprivation Index

\begin{tabular}{|c|c|c|c|c|c|c|c|c|}
\hline \multirow{3}{*}{$\begin{array}{l}\text { Years } \\
\text { to } \\
\text { birth }\end{array}$} & \multicolumn{4}{|c|}{$\begin{array}{c}\text { highly deprived areas } \\
\text { (deprivation score: } 9 \text { or } 10 \text { ) }\end{array}$} & \multicolumn{4}{|c|}{$\begin{array}{c}\text { less deprived areas } \\
\text { (deprivation score of } 8 \text { and less) }\end{array}$} \\
\hline & \multicolumn{2}{|c|}{ NZ European } & \multicolumn{2}{|c|}{ Māori } & \multicolumn{2}{|c|}{ NZ European } & \multicolumn{2}{|c|}{ Māori } \\
\hline & $\begin{array}{c}\operatorname{count}^{\dagger} \\
(1)\end{array}$ & $\begin{array}{l}\text { binary }^{\ddagger} \\
(2)\end{array}$ & $\begin{array}{c}\operatorname{count}^{\dagger} \\
(3)\end{array}$ & $\begin{array}{l}\text { binary } \\
(4)\end{array}$ & $\operatorname{count}^{\dagger}$ & $\begin{array}{l}\text { binary }^{\ddagger} \\
(6)\end{array}$ & $\begin{array}{c}\operatorname{count}^{\dagger} \\
(7)\end{array}$ & $\begin{array}{c}\operatorname{binary}^{\ddagger} \\
(8)\end{array}$ \\
\hline \multicolumn{9}{|c|}{ Panel A: Full sample } \\
\hline 1 & $\begin{array}{c}-0.065^{* *} \\
(0.027)\end{array}$ & $\begin{array}{r}-0.035^{*} \\
(0.019)\end{array}$ & $\begin{array}{c}0.005 \\
(0.022)\end{array}$ & $\begin{array}{c}0.002 \\
(0.016)\end{array}$ & $\begin{array}{c}-0.034^{* *} \\
(0.013)\end{array}$ & $\begin{array}{c}-0.018^{*} \\
(0.01)\end{array}$ & $\begin{array}{l}-0.007 \\
(0.027)\end{array}$ & $\begin{array}{c}0.009 \\
(0.019)\end{array}$ \\
\hline 2 & $\begin{array}{l}-0.058^{*} \\
(0.034)\end{array}$ & $\begin{array}{l}-0.031 \\
(0.022)\end{array}$ & $\begin{array}{l}-0.017 \\
(0.028)\end{array}$ & $\begin{array}{l}-0.005 \\
(0.018)\end{array}$ & $\begin{array}{c}-0.051^{* * *} \\
(0.017)\end{array}$ & $\begin{array}{l}-0.019^{*} \\
(0.012)\end{array}$ & $\begin{array}{l}-0.023 \\
(0.034)\end{array}$ & $\begin{array}{c}0.002 \\
(0.021)\end{array}$ \\
\hline 3 & $\begin{array}{c}-0.077^{* *} \\
(0.039)\end{array}$ & $\begin{array}{c}-0.051^{* *} \\
(0.024)\end{array}$ & $\begin{array}{l}-0.013 \\
(0.031)\end{array}$ & $\begin{array}{c}0.005 \\
(0.018)\end{array}$ & $\begin{array}{c}-0.05^{* *} \\
(0.02)\end{array}$ & $\begin{array}{l}-0.019 \\
(0.012)\end{array}$ & $\begin{array}{l}-0.036 \\
(0.038)\end{array}$ & $\begin{array}{c}0.001 \\
(0.023)\end{array}$ \\
\hline 4 & $\begin{array}{c}-0.085^{* *} \\
(0.042)\end{array}$ & $\begin{array}{c}-0.049^{* *} \\
(0.024)\end{array}$ & $\begin{array}{l}-0.031 \\
(0.034)\end{array}$ & $\begin{array}{l}-0.008 \\
(0.019)\end{array}$ & $\begin{array}{c}-0.055^{* *} \\
(0.022)\end{array}$ & $\begin{array}{l}-0.019 \\
(0.013)\end{array}$ & $\begin{array}{c}-0.027 \\
(0.042)\end{array}$ & $\begin{array}{c}0.015 \\
(0.023)\end{array}$ \\
\hline 5 & $\begin{array}{c}-0.100^{* *} \\
(0.045)\end{array}$ & $\begin{array}{c}-0.049^{* *} \\
(0.025)\end{array}$ & $\begin{array}{c}-0.031 \\
(0.036)\end{array}$ & $\begin{array}{l}-0.007 \\
(0.019)\end{array}$ & $\begin{array}{c}-0.059^{* *} \\
(0.023)\end{array}$ & $\begin{array}{c}-0.020 \\
(0.013)\end{array}$ & $\begin{array}{l}-0.016 \\
(0.044)\end{array}$ & $\begin{array}{c}0.022 \\
(0.023)\end{array}$ \\
\hline 6 & $\begin{array}{c}-0.094^{* *} \\
(0.047)\end{array}$ & $\begin{array}{c}-0.043^{*} \\
(0.025)\end{array}$ & $\begin{array}{l}-0.020 \\
(0.037)\end{array}$ & $\begin{array}{c}-0.002 \\
(0.019)\end{array}$ & $\begin{array}{c}-0.059^{* *} \\
(0.025)\end{array}$ & $\begin{array}{l}-0.013 \\
(0.014)\end{array}$ & $\begin{array}{l}-0.001 \\
(0.046)\end{array}$ & $\begin{array}{c}0.037 \\
(0.024)\end{array}$ \\
\hline 7 & $\begin{array}{c}-0.091^{*} \\
(0.049)\end{array}$ & $\begin{array}{c}-0.04 \\
(0.025)\end{array}$ & $\begin{array}{c}-0.026 \\
(0.039)\end{array}$ & $\begin{array}{l}-0.015 \\
(0.019)\end{array}$ & $\begin{array}{c}-0.069^{* * *} \\
(0.025)\end{array}$ & $\begin{array}{l}-0.019 \\
(0.014)\end{array}$ & $\begin{array}{c}0.009 \\
(0.048)\end{array}$ & $\begin{array}{c}0.042 \\
(0.024)\end{array}$ \\
\hline 8 & $\begin{array}{c}-0.099^{* *} \\
(0.050)\end{array}$ & $\begin{array}{c}-0.047^{*} \\
(0.026)\end{array}$ & $\begin{array}{c}-0.024 \\
(0.040)\end{array}$ & $\begin{array}{c}-0.003 \\
(0.019)\end{array}$ & $\begin{array}{c}-0.066^{* *} \\
(0.026)\end{array}$ & $\begin{array}{l}-0.019 \\
(0.014)\end{array}$ & $\begin{array}{c}0.019 \\
(0.049)\end{array}$ & $\begin{array}{c}0.05 \\
(0.024)\end{array}$ \\
\hline 9 & $\begin{array}{c}-0.110^{* *} \\
(0.052)\end{array}$ & $\begin{array}{c}-0.047^{*} \\
(0.026)\end{array}$ & $\begin{array}{c}-0.027 \\
(0.041)\end{array}$ & $\begin{array}{c}0.000 \\
(0.019)\end{array}$ & $\begin{array}{c}-0.058^{* *} \\
(0.027)\end{array}$ & $\begin{array}{c}-0.014 \\
(0.014)\end{array}$ & $\begin{array}{c}0.015 \\
(0.051)\end{array}$ & $\begin{array}{c}0.044 \\
(0.024)\end{array}$ \\
\hline 10 & $\begin{array}{c}-0.112^{* *} \\
(0.053)\end{array}$ & $\begin{array}{l}-0.041 \\
(0.026)\end{array}$ & $\begin{array}{c}-0.031 \\
(0.042)\end{array}$ & $\begin{array}{c}-0.004 \\
(0.02)\end{array}$ & $\begin{array}{c}-0.058^{* *} \\
(0.028)\end{array}$ & $\begin{array}{l}-0.015 \\
(0.014)\end{array}$ & $\begin{array}{c}0.015 \\
(0.053)\end{array}$ & $\begin{array}{c}0.044 \\
(0.024)\end{array}$ \\
\hline$N$ & \multicolumn{2}{|c|}{1122} & \multicolumn{2}{|c|}{2184} & \multicolumn{2}{|c|}{3228} & \multicolumn{2}{|c|}{1464} \\
\hline \multicolumn{9}{|c|}{ Panel B: Serious conviction before birth ${ }^{\diamond}$} \\
\hline 1 & $\begin{array}{c}-0.244^{* *} \\
(0.104)\end{array}$ & $\begin{array}{c}-0.138^{* *} \\
(0.067)\end{array}$ & $\begin{array}{c}0.103 \\
(0.067)\end{array}$ & $\begin{array}{c}0.055 \\
(0.043)\end{array}$ & $\begin{array}{c}-0.137^{* *} \\
(0.063)\end{array}$ & $\begin{array}{c}-0.057 \\
(0.043)\end{array}$ & $\begin{array}{l}-0.057 \\
(0.093)\end{array}$ & $\begin{array}{l}-0.015 \\
(0.056)\end{array}$ \\
\hline 2 & $\begin{array}{c}-0.228^{*} \\
(0.121)\end{array}$ & $\begin{array}{c}-0.118^{*} \\
(0.064)\end{array}$ & $\begin{array}{c}0.063 \\
(0.077)\end{array}$ & $\begin{array}{l}0.038 \\
(0.04)\end{array}$ & $\begin{array}{c}-0.213^{* * *} \\
(0.079)\end{array}$ & $\begin{array}{c}-0.089^{* *} \\
(0.044)\end{array}$ & $\begin{array}{l}-0.111 \\
(0.105)\end{array}$ & $\begin{array}{l}-0.083 \\
(0.052)\end{array}$ \\
\hline 3 & $\begin{array}{c}-0.316^{* *} \\
(0.127)\end{array}$ & $\begin{array}{c}-0.176^{* * *} \\
(0.058)\end{array}$ & $\begin{array}{c}0.058 \\
(0.082)\end{array}$ & $\begin{array}{c}0.01 \\
(0.036)\end{array}$ & $\begin{array}{c}-0.191^{* *} \\
(0.085)\end{array}$ & $\begin{array}{c}-0.056 \\
(0.042)\end{array}$ & $\begin{array}{c}-0.183 \\
(0.117)\end{array}$ & $\begin{array}{c}-0.083 \\
(0.05)\end{array}$ \\
\hline 4 & $\begin{array}{c}-0.332^{* *} \\
(0.13)\end{array}$ & $\begin{array}{c}-0.136^{* *} \\
(0.054)\end{array}$ & $\begin{array}{c}0.055 \\
(0.086)\end{array}$ & $\begin{array}{c}0.015 \\
(0.034)\end{array}$ & $\begin{array}{c}-0.209^{* *} \\
(0.089)\end{array}$ & $\begin{array}{l}-0.043 \\
(0.04)\end{array}$ & $\begin{array}{c}-0.207^{*} \\
(0.119)\end{array}$ & $\begin{array}{l}-0.085 \\
(0.046)\end{array}$ \\
\hline 5 & $\begin{array}{c}-0.318^{* *} \\
(0.133)\end{array}$ & $\begin{array}{c}-0.106^{* *} \\
(0.052)\end{array}$ & $\begin{array}{c}0.068 \\
(0.086)\end{array}$ & $\begin{array}{c}0.019 \\
(0.031)\end{array}$ & $\begin{array}{c}-0.224^{* *} \\
(0.092)\end{array}$ & $\begin{array}{l}-0.051 \\
(0.039)\end{array}$ & $\begin{array}{c}-0.246^{* *} \\
(0.122)\end{array}$ & $\begin{array}{l}-0.062 \\
(0.043)\end{array}$ \\
\hline 6 & $\begin{array}{c}-0.281^{* *} \\
(0.139)\end{array}$ & $\begin{array}{c}-0.108^{* *} \\
(0.051)\end{array}$ & $\begin{array}{c}0.075 \\
(0.087)\end{array}$ & $\begin{array}{l}0.025 \\
(0.03)\end{array}$ & $\begin{array}{c}-0.21^{* *} \\
(0.096)\end{array}$ & $\begin{array}{l}-0.034 \\
(0.039)\end{array}$ & $\begin{array}{c}-0.249^{* *} \\
(0.123)\end{array}$ & $\begin{array}{l}-0.037 \\
(0.041)\end{array}$ \\
\hline 7 & $\begin{array}{c}-0.264^{*} \\
(0.142)\end{array}$ & $\begin{array}{c}-0.103^{* *} \\
(0.051)\end{array}$ & $\begin{array}{c}0.047 \\
(0.088)\end{array}$ & $\begin{array}{l}-0.001 \\
(0.029)\end{array}$ & $\begin{array}{c}-0.247^{* *} \\
(0.097)\end{array}$ & $\begin{array}{c}-0.065^{*} \\
(0.037)\end{array}$ & $\begin{array}{c}-0.204 \\
(0.127)\end{array}$ & $\begin{array}{l}-0.022 \\
(0.04)\end{array}$ \\
\hline 8 & $\begin{array}{c}-0.275^{*} \\
(0.144)\end{array}$ & $\begin{array}{c}-0.117^{* *} \\
(0.05)\end{array}$ & $\begin{array}{c}0.036 \\
(0.091)\end{array}$ & $\begin{array}{l}-0.005 \\
(0.028)\end{array}$ & $\begin{array}{c}-0.259^{* * *} \\
(0.099)\end{array}$ & $\begin{array}{c}-0.069^{*} \\
(0.037)\end{array}$ & $\begin{array}{c}-0.161 \\
(0.13)\end{array}$ & $\begin{array}{l}-0.005 \\
(0.04)\end{array}$ \\
\hline 9 & $\begin{array}{c}-0.292^{* *} \\
(0.148)\end{array}$ & $\begin{array}{c}-0.122^{* *} \\
(0.051)\end{array}$ & $\begin{array}{c}0.038 \\
(0.092)\end{array}$ & $\begin{array}{c}0.013 \\
(0.027)\end{array}$ & $\begin{array}{c}-0.257^{* *} \\
(0.101)\end{array}$ & $\begin{array}{c}-0.067^{*} \\
(0.037)\end{array}$ & $\begin{array}{l}-0.202 \\
(0.134)\end{array}$ & $\begin{array}{l}-0.025 \\
(0.039)\end{array}$ \\
\hline 10 & $\begin{array}{c}-0.316^{* *} \\
(0.15)\end{array}$ & $\begin{array}{c}-0.13^{* * *} \\
(0.05)\end{array}$ & $\begin{array}{c}0.041 \\
(0.094)\end{array}$ & $\begin{array}{c}0.008 \\
(0.026)\end{array}$ & $\begin{array}{c}-0.250^{* *} \\
(0.102)\end{array}$ & $\begin{array}{c}-0.067^{*} \\
(0.037)\end{array}$ & $\begin{array}{c}-0.238^{*} \\
(0.138)\end{array}$ & $\begin{array}{c}-0.05 \\
(0.038)\end{array}$ \\
\hline
\end{tabular}

Notes: The table shows the child-gender related difference (boy vs. girl) of serious convictions up to 10 years after birth based on OLS regressions differentiated by the Social Deprivation Index. Individuals are assigned into high/low deprived areas at the time of child birth. Each coefficient corresponds to a separate regression. ${ }^{\dagger}$ Count refers to the log-transformed accumulated number of convictions $(+1) .{ }^{\ddagger}$ Binary refers to an indicator variable taking the value of 1 if number of convictions are above zero and 0 otherwise. ${ }^{\diamond}$ correspond to all NZ Europeans / Māori with at least one serious pre-birth conviction. Robust standard errors in parentheses, significance level: $* * * \mathrm{p}<0.01, * * \mathrm{p}<0.05$, * $\mathrm{p}<0.1$. 
Table A.11: Child-gender related difference in neighborhood deprivation by ethnicity and pre-birth convictions, differentiated according to the 2006 Social Deprivation Index

\begin{tabular}{|c|c|c|c|c|c|c|c|c|}
\hline \multirow{3}{*}{$\begin{array}{l}\text { Years } \\
\text { to } \\
\text { birth }\end{array}$} & \multicolumn{4}{|c|}{$\begin{array}{c}\text { highly deprived areas } \\
\text { (deprivation score: } 9 \text { or } 10 \text { ) }\end{array}$} & \multicolumn{4}{|c|}{$\begin{array}{c}\text { less deprived areas } \\
\text { (deprivation score of } 8 \text { and less) }\end{array}$} \\
\hline & \multicolumn{2}{|c|}{ NZ European } & \multicolumn{2}{|c|}{ Māori } & \multicolumn{2}{|c|}{ NZ European } & \multicolumn{2}{|c|}{ Māori } \\
\hline & $\begin{array}{c}\Delta(\text { deprived }) \\
(1)\end{array}$ & $\begin{array}{c}\text { Score }^{\dagger} \\
(2)\end{array}$ & $\begin{array}{c}\Delta(\text { deprived }) \\
(3)\end{array}$ & $\begin{array}{c}\text { Score }^{\dagger} \\
(4)\end{array}$ & $\Delta($ deprived $)$ & $\begin{array}{l}\text { Score }^{\dagger} \\
(6)\end{array}$ & $\begin{array}{c}\Delta(\text { deprived }) \\
(7)\end{array}$ & $\begin{array}{l}\text { Score }^{\dagger} \\
(8)\end{array}$ \\
\hline \multicolumn{9}{|c|}{ Panel A: Full sample } \\
\hline 1 & $\begin{array}{l}-0.028 \\
(0.031)\end{array}$ & $\begin{array}{l}-2.892 \\
(6.638)\end{array}$ & $\begin{array}{l}-0.001 \\
(0.018)\end{array}$ & $\begin{array}{c}0.513 \\
(4.953)\end{array}$ & $\begin{array}{c}0.021 \\
(0.014)\end{array}$ & $\begin{array}{l}4.854^{*} \\
(2.802)\end{array}$ & $\begin{array}{c}0.007 \\
(0.026)\end{array}$ & $\begin{array}{c}3.411 \\
(5.513)\end{array}$ \\
\hline 2 & $\begin{array}{r}-0.017 \\
(0.03)\end{array}$ & $\begin{array}{l}-2.967 \\
(6.325)\end{array}$ & $\begin{array}{c}0.028 \\
(0.019)\end{array}$ & $\begin{array}{c}5.112 \\
(5.154)\end{array}$ & $\begin{array}{c}0.018 \\
(0.014)\end{array}$ & $\begin{array}{l}3.151 \\
(2.882)\end{array}$ & $\begin{array}{l}-0.038 \\
(0.026)\end{array}$ & $\begin{array}{l}-6.903 \\
(5.659)\end{array}$ \\
\hline 3 & $\begin{array}{l}-0.028 \\
(0.03)\end{array}$ & $\begin{array}{l}-7.636 \\
(6.081)\end{array}$ & $\begin{array}{l}0.032^{*} \\
(0.019)\end{array}$ & $\begin{array}{l}8.506^{*} \\
(5.092)\end{array}$ & $\begin{array}{c}0.002 \\
(0.014)\end{array}$ & $\begin{array}{l}2.996 \\
(3.034)\end{array}$ & $\begin{array}{l}-0.033 \\
(0.026)\end{array}$ & $\begin{array}{l}-6.847 \\
(5.669)\end{array}$ \\
\hline 4 & $\begin{array}{l}-0.026 \\
(0.03)\end{array}$ & $\begin{array}{l}-9.493 \\
(6.226)\end{array}$ & $\begin{array}{l}0.034^{*} \\
(0.019)\end{array}$ & $\begin{array}{l}9.333^{*} \\
(5.189)\end{array}$ & $\begin{array}{l}0.026^{*} \\
(0.014)\end{array}$ & $\begin{array}{l}5.386^{*} \\
(2.953)\end{array}$ & $\begin{array}{l}-0.002 \\
(0.027)\end{array}$ & $\begin{array}{l}-1.693 \\
(5.629)\end{array}$ \\
\hline 5 & $\begin{array}{c}0.01 \\
(0.03)\end{array}$ & $\begin{array}{l}-3.326 \\
(5.911)\end{array}$ & $\begin{array}{l}0.032 \\
(0.02)\end{array}$ & $\begin{array}{c}5.499 \\
(5.123)\end{array}$ & $\begin{array}{c}0.01 \\
(0.014)\end{array}$ & $\begin{array}{c}3.588 \\
(3.067)\end{array}$ & $\begin{array}{l}-0.015 \\
(0.027)\end{array}$ & $\begin{array}{l}-1.899 \\
(5.848)\end{array}$ \\
\hline 6 & $\begin{array}{l}-0.025 \\
(0.03)\end{array}$ & $\begin{array}{l}-9.71 \\
(6.17)\end{array}$ & $\begin{array}{c}0.01 \\
(0.02)\end{array}$ & $\begin{array}{c}1.453 \\
(5.147)\end{array}$ & $\begin{array}{c}0.016 \\
(0.014)\end{array}$ & $\begin{array}{c}3.47 \\
(2.95)\end{array}$ & $\begin{array}{l}-0.019 \\
(0.027)\end{array}$ & $\begin{array}{c}0.862 \\
(5.784)\end{array}$ \\
\hline 7 & $\begin{array}{l}-0.008 \\
(0.03)\end{array}$ & $\begin{array}{l}-4.329 \\
(6.276)\end{array}$ & $\begin{array}{c}0.02 \\
(0.02)\end{array}$ & $\begin{array}{c}4.632 \\
(5.188)\end{array}$ & $\begin{array}{c}0.035^{* * *} \\
(0.014)\end{array}$ & $\begin{array}{l}7.33^{* *} \\
(2.921)\end{array}$ & $\begin{array}{l}-0.017 \\
(0.027)\end{array}$ & $\begin{array}{l}-0.272 \\
(5.797)\end{array}$ \\
\hline 8 & $\begin{array}{l}-0.045 \\
(0.029)\end{array}$ & $\begin{array}{c}-13.737^{* *} \\
(6.185)\end{array}$ & $\begin{array}{l}-0.01 \\
(0.02)\end{array}$ & $\begin{array}{l}-2.292 \\
(5.227)\end{array}$ & $\begin{array}{c}0.021 \\
(0.014)\end{array}$ & $\begin{array}{c}2.285 \\
(3.031)\end{array}$ & $\begin{array}{l}-0.009 \\
(0.027)\end{array}$ & $\begin{array}{l}0.755 \\
(5.843)\end{array}$ \\
\hline 9 & $\begin{array}{l}-0.018 \\
(0.029)\end{array}$ & $\begin{array}{c}-10.992^{*} \\
(6.292)\end{array}$ & $\begin{array}{l}-0.02 \\
(0.02)\end{array}$ & $\begin{array}{l}-3.226 \\
(5.174)\end{array}$ & $\begin{array}{c}0.014 \\
(0.014)\end{array}$ & $\begin{array}{c}4.087 \\
(3.027)\end{array}$ & $\begin{array}{l}-0.028 \\
(0.027)\end{array}$ & $\begin{array}{l}-5.728 \\
(5.835)\end{array}$ \\
\hline 10 & $\begin{array}{c}-0.073^{* *} \\
(0.029)\end{array}$ & $\begin{array}{c}-17.177^{* * *} \\
(6.492)\end{array}$ & $\begin{array}{l}-0.014 \\
(0.021)\end{array}$ & $\begin{array}{l}0.114 \\
(5.21)\end{array}$ & $\begin{array}{c}0.017 \\
(0.014)\end{array}$ & $\begin{array}{l}5.295^{*} \\
(3.006)\end{array}$ & $\begin{array}{l}-0.007 \\
(0.027)\end{array}$ & $\begin{array}{c}0.451 \\
(6.025)\end{array}$ \\
\hline$N$ & \multicolumn{2}{|c|}{1080} & \multicolumn{2}{|c|}{2079} & \multicolumn{2}{|l|}{3126} & \multicolumn{2}{|c|}{1392} \\
\hline \multicolumn{9}{|c|}{ Panel B: Serious conviction before birth ${ }^{\diamond}$} \\
\hline 1 & $\begin{array}{c}0.093 \\
(0.069)\end{array}$ & $\begin{array}{c}16.626 \\
(16.359)\end{array}$ & $\begin{array}{c}-0.026 \\
(0.038)\end{array}$ & $\begin{array}{c}2.485 \\
(10.603)\end{array}$ & $\begin{array}{l}-0.005 \\
(0.041)\end{array}$ & $\begin{array}{c}4.781 \\
(9.073)\end{array}$ & $\begin{array}{l}-0.031 \\
(0.058)\end{array}$ & $\begin{array}{c}-1.948 \\
(14.735)\end{array}$ \\
\hline 2 & $\begin{array}{c}0.071 \\
(0.069)\end{array}$ & $\begin{array}{c}15.87 \\
(13.507)\end{array}$ & $\begin{array}{c}0.039 \\
(0.038)\end{array}$ & $\begin{array}{c}7.044 \\
(10.969)\end{array}$ & $\begin{array}{l}-0.009 \\
(0.04)\end{array}$ & $\begin{array}{l}-0.408 \\
(8.253)\end{array}$ & $\begin{array}{c}-0.142^{* *} \\
(0.059)\end{array}$ & $\begin{array}{l}-24.861^{*} \\
(14.286)\end{array}$ \\
\hline 3 & $\begin{array}{c}0.084 \\
(0.068)\end{array}$ & $\begin{array}{c}10.611 \\
(13.093)\end{array}$ & $\begin{array}{l}-0.011 \\
(0.04)\end{array}$ & $\begin{array}{c}-0.843 \\
(10.926)\end{array}$ & $\begin{array}{l}-0.036 \\
(0.041)\end{array}$ & $\begin{array}{l}-6.882 \\
(8.277)\end{array}$ & $\begin{array}{c}-0.133^{* *} \\
(0.058)\end{array}$ & $\begin{array}{l}-22.107 \\
(14.849)\end{array}$ \\
\hline 4 & $\begin{array}{l}0.064 \\
(0.07)\end{array}$ & $\begin{array}{c}0.152 \\
(15.885)\end{array}$ & $\begin{array}{l}-0.005 \\
(0.041)\end{array}$ & $\begin{array}{c}2.52 \\
(11.39)\end{array}$ & $\begin{array}{l}-0.028 \\
(0.04)\end{array}$ & $\begin{array}{l}-3.776 \\
(8.396)\end{array}$ & $\begin{array}{c}0.017 \\
(0.059)\end{array}$ & $\begin{array}{c}1.163 \\
(14.792)\end{array}$ \\
\hline 5 & $\begin{array}{r}-0.001 \\
(0.07)\end{array}$ & $\begin{array}{c}-6.125 \\
(13.636)\end{array}$ & $\begin{array}{c}0.05 \\
(0.04)\end{array}$ & $\begin{array}{c}-1.846 \\
(10.758)\end{array}$ & $\begin{array}{l}-0.014 \\
(0.041)\end{array}$ & $\begin{array}{l}1.309 \\
(9.634)\end{array}$ & $\begin{array}{l}-0.051 \\
(0.058)\end{array}$ & $\begin{array}{c}-11.093 \\
(14.183)\end{array}$ \\
\hline 6 & $\begin{array}{c}0.011 \\
(0.066)\end{array}$ & $\begin{array}{c}-6.387 \\
(14.293)\end{array}$ & $\begin{array}{l}-0.003 \\
(0.039)\end{array}$ & $\begin{array}{c}-6.346 \\
(10.912)\end{array}$ & $\begin{array}{l}-0.016 \\
(0.041)\end{array}$ & $\begin{array}{c}-2.024 \\
(8.7)\end{array}$ & $\begin{array}{l}-0.068 \\
(0.058)\end{array}$ & $\begin{array}{c}-6.295 \\
(14.042)\end{array}$ \\
\hline 7 & $\begin{array}{c}0.044 \\
(0.068)\end{array}$ & $\begin{array}{c}-0.384 \\
(15.379)\end{array}$ & $\begin{array}{c}-0.01 \\
(0.039)\end{array}$ & $\begin{array}{c}-2.304 \\
(11.408)\end{array}$ & $\begin{array}{c}0.025 \\
(0.039)\end{array}$ & $\begin{array}{l}12.777 \\
(8.405)\end{array}$ & $\begin{array}{l}0.016 \\
(0.06)\end{array}$ & $\begin{array}{c}5.311 \\
(14.014)\end{array}$ \\
\hline 8 & $\begin{array}{c}0.017 \\
(0.068)\end{array}$ & $\begin{array}{c}-4.158 \\
(13.972)\end{array}$ & $\begin{array}{l}-0.07^{*} \\
(0.042)\end{array}$ & $\begin{array}{c}-14.06 \\
(11.858)\end{array}$ & $\begin{array}{c}0.006 \\
(0.041)\end{array}$ & $\begin{array}{l}1.713 \\
(8.496)\end{array}$ & $\begin{array}{c}0.018 \\
(0.059)\end{array}$ & $\begin{array}{c}4.367 \\
(14.337)\end{array}$ \\
\hline 9 & $\begin{array}{l}-0.044 \\
(0.065)\end{array}$ & $\begin{array}{l}-15.538 \\
(13.814)\end{array}$ & $\begin{array}{l}-0.057 \\
(0.043)\end{array}$ & $\begin{array}{c}-11.67 \\
(11.584)\end{array}$ & $\begin{array}{c}-0.069^{*} \\
(0.04)\end{array}$ & $\begin{array}{l}-6.929 \\
(8.731)\end{array}$ & $\begin{array}{l}-0.051 \\
(0.058)\end{array}$ & $\begin{array}{l}-18.864 \\
(14.042)\end{array}$ \\
\hline 10 & $\begin{array}{l}-0.067 \\
(0.069)\end{array}$ & $\begin{array}{c}-15.148 \\
(14.794)\end{array}$ & $\begin{array}{l}-0.023 \\
(0.043)\end{array}$ & $\begin{array}{c}0.348 \\
(11.317)\end{array}$ & $\begin{array}{c}-0.03 \\
(0.041)\end{array}$ & $\begin{array}{c}3.751 \\
(8.329)\end{array}$ & $\begin{array}{l}-0.041 \\
(0.059)\end{array}$ & $\begin{array}{c}-2.831 \\
(14.473)\end{array}$ \\
\hline$N$ & 22 & & 486 & & 474 & & 279 & \\
\hline
\end{tabular}

Notes: The table shows the child-gender related difference (boy vs. girl) in neighborhood deprivation up to 10 years after birth based on probit/OLS regressions differentiated by the Social Deprivation Index. Individuals are assigned into high/low deprived areas at the time of child birth. Each coefficient corresponds to a separate regression. $\Delta$ (deprived $)$ refers to an indicator variable taking the value of 1 if neighborhood has a deprivation scale of 9 or 10 and 0 otherwise. ${ }^{\dagger}$ refers to the social deprivation score with a mean of 1000 index points and a standard deviation 100 index points. ${ }^{\diamond}$ correspond to all NZ Europeans / Māori with at least one serious pre-birth conviction. Robust standard errors in parentheses, significance level: ${ }^{* * *} \mathrm{p}<0.01,{ }^{* *} \mathrm{p}<0.05,{ }^{*} \mathrm{p}<0.1$. 
Table A.12: Probability to receive a conviction as outcome of a charge in the period of two years up to six months before birth of the first child

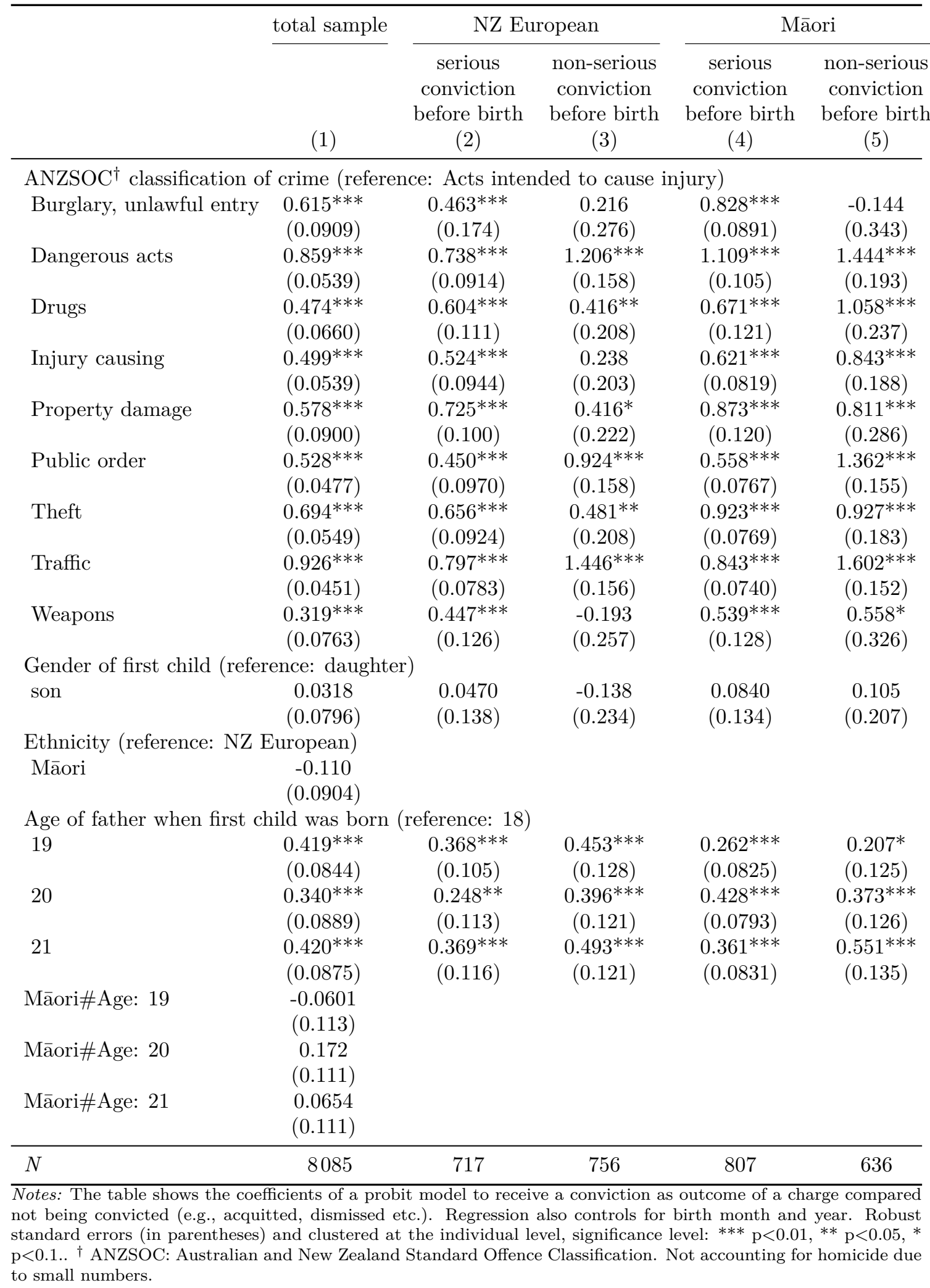


Table A.13: Labour market effects of child gender, marginal effects (total sample)

\begin{tabular}{|c|c|c|c|c|c|c|c|c|c|c|c|c|c|c|}
\hline \multirow{2}{*}{$\begin{array}{l}\text { Years } \\
\text { to birth }\end{array}$} & \multicolumn{7}{|c|}{ NZ European } & \multicolumn{7}{|c|}{ Māori } \\
\hline & (1) & $(2)$ & $(3)$ & $(4)$ & $(5)$ & (6) & (7) & (1) & $(2)$ & (3) & (4) & $(5)$ & (6) & (7) \\
\hline \multirow[t]{2}{*}{1} & -0.019 & -0.008 & -0.012 & 0.004 & -0.001 & 0.044 & -0.011 & 0.000 & -0.005 & 0.005 & -0.010 & -0.004 & -0.016 & 0.019 \\
\hline & $(0.030)$ & $(0.016)$ & $(0.017)$ & $(0.013)$ & $(0.005)$ & $(0.045)$ & $(0.014)$ & $(0.043)$ & $(0.022)$ & $(0.025)$ & $(0.016)$ & $(0.003)$ & $(0.040)$ & $(0.016)$ \\
\hline \multirow[t]{2}{*}{2} & -0.005 & 0 & -0.005 & -0.001 & -0.004 & -0.007 & -0.004 & -0.013 & -0.011 & -0.002 & -0.016 & -0.004 & -0.042 & 0.008 \\
\hline & $(0.031)$ & $(0.015)$ & $(0.019)$ & $(0.014)$ & $(0.008)$ & $(0.046)$ & $(0.017)$ & $(0.044)$ & $(0.020)$ & $(0.027)$ & $(0.016)$ & $(0.004)$ & $(0.039)$ & $(0.019)$ \\
\hline \multirow[t]{2}{*}{3} & 0.030 & 0.020 & 0.010 & -0.002 & -0.003 & 0.000 & 0.004 & 0.008 & -0.009 & 0.017 & -0.022 & -0.001 & -0.044 & -0.003 \\
\hline & $(0.031)$ & $(0.014)$ & $(0.020)$ & $(0.014)$ & $(0.009)$ & $(0.045)$ & $(0.018)$ & $(0.044)$ & $(0.020)$ & $(0.028)$ & $(0.016)$ & $(0.005)$ & $(0.039)$ & $(0.021)$ \\
\hline \multirow[t]{2}{*}{4} & 0.050 & $0.026^{*}$ & 0.024 & 0.003 & -0.001 & -0.013 & -0.002 & -0.006 & -0.009 & 0.003 & $-0.028^{*}$ & -0.003 & -0.030 & -0.007 \\
\hline & $(0.032)$ & $(0.014)$ & $(0.021)$ & $(0.014)$ & $(0.011)$ & $(0.046)$ & $(0.019)$ & $(0.044)$ & $(0.019)$ & $(0.029)$ & $(0.015)$ & $(0.006)$ & $(0.039)$ & $(0.021)$ \\
\hline \multirow[t]{2}{*}{5} & 0.040 & 0.020 & 0.020 & 0.001 & 0.015 & 0.021 & -0.005 & -0.007 & -0.006 & -0.001 & -0.014 & -0.002 & -0.041 & 0.004 \\
\hline & $(0.032)$ & $(0.014)$ & $(0.021)$ & $(0.014)$ & $(0.012)$ & $(0.046)$ & $(0.019)$ & $(0.044)$ & $(0.018)$ & $(0.029)$ & $(0.015)$ & $(0.007)$ & $(0.039)$ & $(0.022)$ \\
\hline \multirow[t]{2}{*}{6} & 0.045 & 0.019 & 0.026 & -0.002 & $0.027^{* *}$ & 0.026 & -0.007 & 0.003 & 0.005 & -0.002 & -0.012 & -0.004 & -0.019 & 0.009 \\
\hline & $(0.032)$ & $(0.014)$ & $(0.022)$ & $(0.014)$ & $(0.013)$ & $(0.046)$ & $(0.020)$ & $(0.044)$ & $(0.018)$ & $(0.029)$ & $(0.014)$ & $(0.008)$ & $(0.040)$ & $(0.022)$ \\
\hline \multirow[t]{2}{*}{7} & 0.033 & 0.014 & 0.019 & 0.001 & $0.035^{* *}$ & 0.006 & -0.004 & -0.002 & -0.001 & -0.002 & -0.009 & 0.000 & -0.021 & 0.011 \\
\hline & $(0.032)$ & $(0.013)$ & $(0.022)$ & $(0.014)$ & $(0.014)$ & $(0.047)$ & $(0.020)$ & $(0.044)$ & $(0.017)$ & $(0.030)$ & $(0.014)$ & $(0.009)$ & $(0.041)$ & $(0.023)$ \\
\hline \multirow[t]{2}{*}{8} & 0.028 & 0.012 & 0.017 & 0.003 & $0.047 * * *$ & 0.016 & -0.012 & -0.017 & -0.008 & -0.010 & -0.011 & 0.001 & -0.012 & 0.015 \\
\hline & $(0.032)$ & $(0.013)$ & $(0.022)$ & $(0.014)$ & $(0.015)$ & $(0.048)$ & $(0.021)$ & $(0.044)$ & $(0.017)$ & $(0.030)$ & $(0.014)$ & $(0.009)$ & $(0.041)$ & $(0.023)$ \\
\hline \multirow[t]{2}{*}{9} & 0.030 & 0.011 & 0.019 & -0.001 & $0.046^{* * *}$ & 0.037 & -0.009 & -0.014 & -0.005 & -0.009 & -0.007 & -0.004 & -0.021 & 0.015 \\
\hline & $(0.032)$ & $(0.013)$ & $(0.022)$ & $(0.014)$ & $(0.016)$ & $(0.049)$ & $(0.021)$ & $(0.044)$ & $(0.017)$ & $(0.030)$ & $(0.014)$ & $(0.011)$ & $(0.042)$ & $(0.023)$ \\
\hline \multirow[t]{2}{*}{10} & 0.019 & 0.007 & 0.012 & -0.004 & $0.046^{* * *}$ & 0.045 & -0.012 & -0.001 & 0.001 & -0.001 & -0.007 & -0.004 & -0.019 & 0.020 \\
\hline & $(0.032)$ & $(0.013)$ & $(0.023)$ & $(0.014)$ & $(0.017)$ & $(0.049)$ & $(0.021)$ & $(0.044)$ & $(0.017)$ & $(0.030)$ & $(0.013)$ & $(0.011)$ & $(0.042)$ & $(0.023)$ \\
\hline$N$ & & & & 4404 & & & & & & & 3681 & & & \\
\hline
\end{tabular}

Notes: The table reports the results of the gender of the child on various labor market indicators, the probability of marriage, and enrolled in formal/non-formal tertiary qualifications at government-funded tertiary education organisations differentiated by ethnic group. Each coefficient corresponds to a separate regression. Column (1) shows the sum of monthly income from wages and salaries (log transformed). Column (2) shows the mean monthly income from wages and salaries (log transformed). Column (3) shows the number of employed months receiving income from wages and salaries (log transformed). Column (4) shows the binary indicator on having received benefits at all. Column (5) shows the binary indicator on being married. Column (6) shows the number of months receiving benefits (log transformed). Column (7) shows the binary indicator on being enrolled at tertiary education since birth of the child (only including individuals who were not enrolled before birth of the child). OLS/probit regressions with robust standard errors in parentheses, significance level: ${ }^{* * *} \mathrm{p}<0.01,{ }^{* *} \mathrm{p}<0.05,{ }^{*} \mathrm{p}<0.1$. 
Table A.14: Labour market effects of child gender, marginal effects (serious conviction before birth)

\begin{tabular}{|c|c|c|c|c|c|c|c|c|c|c|c|c|c|c|}
\hline \multirow{2}{*}{$\begin{array}{l}\text { Years } \\
\text { to birth }\end{array}$} & \multicolumn{7}{|c|}{ NZ European } & \multicolumn{7}{|c|}{ Māori } \\
\hline & (1) & $(2)$ & (3) & (4) & $(5)$ & (6) & $(7)$ & (1) & $(2)$ & (3) & (4) & $(5)$ & $(6)$ & (7) \\
\hline \multirow[t]{2}{*}{1} & 0.038 & 0.002 & 0.036 & -0.018 & -0.045 & -0.046 & -0.031 & -0.083 & -0.065 & -0.017 & 0.001 & -0.083 & -0.015 & 0.028 \\
\hline & $(0.097)$ & $(0.051)$ & $(0.056)$ & $(0.036)$ & $(0.047)$ & $(0.068)$ & $(0.035)$ & $(0.107)$ & $(0.054)$ & $(0.063)$ & $(0.034)$ & $(0.057)$ & $(0.067)$ & $(0.035)$ \\
\hline \multirow[t]{2}{*}{2} & 0.080 & 0.018 & 0.063 & -0.024 & 0.004 & -0.110 & 0.018 & -0.055 & -0.031 & -0.023 & -0.019 & 0.004 & -0.031 & 0.011 \\
\hline & $(0.101)$ & $(0.048)$ & $(0.062)$ & $(0.033)$ & $(0.023)$ & $(0.074)$ & $(0.042)$ & $(0.105)$ & $(0.049)$ & $(0.067)$ & $(0.031)$ & $(0.019)$ & $(0.066)$ & $(0.040)$ \\
\hline \multirow[t]{2}{*}{3} & $0.175^{*}$ & 0.068 & $0.107^{*}$ & -0.025 & -0.009 & $-0.144^{*}$ & 0.002 & 0.024 & -0.001 & 0.025 & -0.040 & $0.029^{*}$ & -0.061 & -0.029 \\
\hline & $(0.101)$ & $(0.044)$ & $(0.064)$ & $(0.03)$ & $(0.025)$ & $(0.075)$ & $(0.045)$ & $(0.110)$ & $(0.048)$ & $(0.071)$ & $(0.028)$ & $(0.016)$ & $(0.067)$ & $(0.045)$ \\
\hline \multirow[t]{2}{*}{4} & $0.256^{* *}$ & $0.103^{* *}$ & $0.153^{* *}$ & -0.015 & 0.008 & $-0.166^{* *}$ & 0.006 & 0.029 & 0.005 & 0.024 & -0.027 & $0.031^{* *}$ & -0.049 & -0.046 \\
\hline & $(0.108)$ & $(0.045)$ & $(0.071)$ & $(0.027)$ & $(0.019)$ & $(0.079)$ & $(0.047)$ & $(0.113)$ & $(0.046)$ & $(0.076)$ & $(0.025)$ & $(0.014)$ & $(0.067)$ & $(0.047)$ \\
\hline \multirow[t]{2}{*}{5} & $0.287^{* *}$ & $0.100^{* *}$ & $0.187^{* *}$ & -0.002 & 0.006 & $-0.161^{* *}$ & -0.006 & 0.025 & 0.008 & 0.017 & -0.012 & $0.031^{* *}$ & -0.019 & -0.044 \\
\hline & $(0.113)$ & $(0.046)$ & $(0.075)$ & $(0.025)$ & $(0.016)$ & $(0.079)$ & $(0.048)$ & $(0.111)$ & $(0.044)$ & $(0.076)$ & $(0.023)$ & $(0.014)$ & $(0.064)$ & $(0.048)$ \\
\hline \multirow[t]{2}{*}{6} & $0.322^{* * *}$ & $0.105^{* *}$ & $0.217^{* * *} *$ & -0.006 & 0.012 & $-0.166^{* *}$ & -0.006 & 0.028 & 0.007 & 0.021 & -0.010 & 0.021 & -0.006 & 0.000 \\
\hline & $(0.113)$ & $(0.045)$ & $(0.075)$ & $(0.025)$ & $(0.018)$ & $(0.080)$ & $(0.049)$ & $(0.113)$ & $(0.044)$ & $(0.078)$ & $(0.021)$ & $(0.014)$ & $(0.064)$ & $(0.050)$ \\
\hline \multirow[t]{2}{*}{7} & $0.308^{* * *}$ & $0.100^{* *}$ & $0.208^{* * *}$ & -0.004 & 0.008 & $-0.193^{* *}$ & -0.011 & -0.013 & -0.016 & 0.002 & 0.010 & 0.017 & -0.040 & -0.003 \\
\hline & $(0.112)$ & $(0.043)$ & $(0.075)$ & $(0.024)$ & $(0.020)$ & $(0.082)$ & $(0.051)$ & $(0.114)$ & $(0.044)$ & $(0.079)$ & $(0.020)$ & $(0.015)$ & $(0.066)$ & $(0.052)$ \\
\hline \multirow[t]{2}{*}{8} & $0.337^{* * *}$ & $0.110^{* *}$ & $0.227^{* * *}$ & -0.004 & 0.019 & $-0.199 * *$ & -0.024 & -0.014 & -0.020 & 0.006 & 0.003 & 0.015 & -0.049 & 0.018 \\
\hline & $(0.115)$ & $(0.044)$ & $(0.078)$ & $(0.024)$ & $(0.022)$ & $(0.083)$ & $(0.050)$ & $(0.115)$ & $(0.044)$ & $(0.080)$ & $(0.019)$ & $(0.016)$ & $(0.065)$ & $(0.052)$ \\
\hline \multirow[t]{2}{*}{9} & $0.316^{* * *}$ & $0.102^{* *}$ & $0.214^{* * *}$ & -0.015 & 0.037 & $-0.168^{* *}$ & -0.008 & 0.001 & -0.013 & 0.014 & 0.004 & 0.010 & -0.051 & 0.027 \\
\hline & $(0.114)$ & $(0.043)$ & $(0.077)$ & $(0.023)$ & $(0.026)$ & $(0.085)$ & $(0.051)$ & $(0.112)$ & $(0.042)$ & $(0.079)$ & $(0.018)$ & $(0.015)$ & $(0.066)$ & $(0.052)$ \\
\hline \multirow[t]{2}{*}{10} & $0.261^{* *}$ & $0.083^{* *}$ & $0.178^{* *}$ & -0.016 & 0.026 & $-0.179 * *$ & -0.026 & 0.026 & -0.005 & 0.031 & -0.003 & 0.013 & -0.035 & 0.027 \\
\hline & $(0.113)$ & $(0.042)$ & $(0.077)$ & $(0.023)$ & $(0.028)$ & $(0.085)$ & $(0.051)$ & $(0.114)$ & $(0.041)$ & $(0.08)$ & $(0.017)$ & $(0.016)$ & $(0.069)$ & $(0.052)$ \\
\hline$N$ & & & & 717 & & & & & & & 807 & & & \\
\hline
\end{tabular}

Notes: The table reports the results of the gender of the child on various labor market indicators, the probability of marriage, and enrolled in formal/non-formal tertiary qualifications at government-funded tertiary education organisations differentiated by ethnic group. Each coefficient corresponds to a separate regression. Column (1) shows the sum of monthly income from wages and salaries (log transformed). Column (2) shows the mean monthly income from wages and salaries (log transformed). Column (3) shows the number of employed months receiving income from wages and salaries (log transformed). Column (4) shows the binary indicator on having received benefits at all. Column (5) shows the binary indicator on being married. Column (6) shows the number of months receiving benefits (log transformed). Column (7) shows the binary indicator on being enrolled at tertiary education since birth of the child (only including individuals who were not enrolled before birth of the child). OLS/probit regressions with robust standard errors in parentheses, significance level: ${ }^{* * *} \mathrm{p}<0.01,{ }^{* *} \mathrm{p}<0.05,{ }^{*} \mathrm{p}<0.1$. 


\section{B Disclaimer}

The results in this paper are not official statistics, they have been created for research purposes from the Integrated Data Infrastructure (IDI), managed by Statistics New Zealand. The opinions, findings, recommendations, and conclusions expressed in this paper are those of the authors, not Statistics NZ.

The results are based in part on tax data supplied by Inland Revenue to Statistics NZ under the Tax Administration Act 1994. This tax data must be used only for statistical purposes, and no individual information may be published or disclosed in any other form, or provided to Inland Revenue for administrative or regulatory purposes. Any person who has had access to the unit record data has certified that they have been shown, have read, and have understood section 81 of the Tax Administration Act 1994, which relates to secrecy. Any discussion of data limitations or weaknesses is in the context of using the IDI for statistical purposes, and is not related to the data's ability to support Inland Revenue's core operational requirements.

Access to the anonymised data used in this study was provided by Statistics NZ in accordance with security and confidentiality provisions of the Statistics Act 1975. Only people authorised by the Statistics Act 1975 are allowed to see data about a particular person, household, business, or organisation, and the results in this paper have been confidentialised to protect these groups from identification. Careful consideration has been given to the privacy, security, and confidentiality issues associated with using administrative and survey data in the IDI.

Further detail can be found in the Privacy impact assessment for the Integrated Data Infrastructure available from www.stats.govt.nz. 
CENTRE FOR ECONOMIC PERFORMANCE

Recent Discussion Papers

\begin{tabular}{|c|c|c|}
\hline 1731 & $\begin{array}{l}\text { Andreas Diemer } \\
\text { Tanner Regan }\end{array}$ & $\begin{array}{l}\text { No inventor is an island: social connectedness } \\
\text { and the geography of knowledge flows in the } \\
\text { US }\end{array}$ \\
\hline 1730 & $\begin{array}{l}\text { Hanming Fang } \\
\text { Chunmian Ge } \\
\text { Hanwei Huang } \\
\text { Hongbin Li }\end{array}$ & $\begin{array}{l}\text { Pandemics, global supply chains, and local } \\
\text { labor demand: evidence from } 100 \text { million } \\
\text { posted jobs in China }\end{array}$ \\
\hline 1729 & $\begin{array}{l}\text { Ria Ivandić } \\
\text { Tom Kirchmaier } \\
\text { Ben Linton }\end{array}$ & $\begin{array}{l}\text { Changing patterns of domestic abuse during } \\
\text { COVID-19 lockdown }\end{array}$ \\
\hline 1728 & $\begin{array}{l}\text { Jonathan Colmer } \\
\text { Ralf Martin } \\
\text { Mirabelle Muûls } \\
\text { Ulrich J. Wagner }\end{array}$ & $\begin{array}{l}\text { Does pricing carbon mitigate climate change? } \\
\text { Firm-level evidence from the European Union } \\
\text { emissions trading scheme }\end{array}$ \\
\hline 1727 & $\begin{array}{l}\text { Tony Beatton } \\
\text { Michael P. Kidd } \\
\text { Matteo Sandi }\end{array}$ & School indiscipline and crime \\
\hline 1726 & $\begin{array}{l}\text { Maximilian v. Ehrlich } \\
\text { Henry G. Overman }\end{array}$ & $\begin{array}{l}\text { Place-based policies and spatial disparities } \\
\text { across European cities }\end{array}$ \\
\hline 1725 & $\begin{array}{l}\text { Gabriel M. Ahlfeldt } \\
\text { Thilo N. H. Albers } \\
\text { Kristian Behrens }\end{array}$ & Prime Locations \\
\hline 1724 & $\begin{array}{l}\text { Benjamin Handel } \\
\text { Jonathan Kolstad } \\
\text { Thomas Minten } \\
\text { Johannes Spinnewijn }\end{array}$ & $\begin{array}{l}\text { The Social Determinants of Choice Quality: } \\
\text { Evidence from Health Insurance in the } \\
\text { Netherlands }\end{array}$ \\
\hline 1723 & $\begin{array}{l}\text { Claudia Hupkau } \\
\text { Barbara Petrongolo }\end{array}$ & $\begin{array}{l}\text { Work, Care and Gender During the Covid-19 } \\
\text { Crisis }\end{array}$ \\
\hline
\end{tabular}




\begin{tabular}{|c|c|c|}
\hline 1722 & $\begin{array}{l}\text { Ross Levine } \\
\text { Yona Rubinstein }\end{array}$ & $\begin{array}{l}\text { Selection Into Entrepreneurship and Self- } \\
\text { Employment }\end{array}$ \\
\hline 1721 & Sandra McNally & $\begin{array}{l}\text { Gender Differences in Tertiary Education: } \\
\text { What Explains STEM Participation? }\end{array}$ \\
\hline 1720 & $\begin{array}{l}\text { Edoardo di Porto } \\
\text { Paolo Naticchioni } \\
\text { Vincenzo Scrutinio }\end{array}$ & $\begin{array}{l}\text { Partial Lockdown and the Spread of Covid- } \\
\text { 19: Lessons From the Italian Case }\end{array}$ \\
\hline 1719 & $\begin{array}{l}\text { Swati Dhingra } \\
\text { Stephen Machin }\end{array}$ & The Crisis and Job Guarantees in Urban India \\
\hline 1718 & Stephen J. Redding & Trade and Geography \\
\hline 1717 & $\begin{array}{l}\text { Arun Advani } \\
\text { Felix Koenig } \\
\text { Lorenzo Pessina } \\
\text { Andy Summers }\end{array}$ & $\begin{array}{l}\text { Importing Inequality: Immigration and the } \\
\text { Top } 1 \text { Percent }\end{array}$ \\
\hline 1716 & $\begin{array}{l}\text { Pol Antràs } \\
\text { Stephen J. Redding } \\
\text { Esteban Rossi-Hansberg }\end{array}$ & Globalization and Pandemics \\
\hline 1715 & $\begin{array}{l}\text { Davin Chor } \\
\text { Kalina Manova } \\
\text { Zhihong Yu }\end{array}$ & $\begin{array}{l}\text { Growing Like China: Firm Performance and } \\
\text { Global Production Line Position }\end{array}$ \\
\hline 1714 & $\begin{array}{l}\text { Luna Bellani } \\
\text { Anselm Hager } \\
\text { Stephan E. Maurer }\end{array}$ & $\begin{array}{l}\text { The Long Shadow of Slavery: The Persistence } \\
\text { of Slave Owners in Southern Law-Making }\end{array}$ \\
\hline 1713 & $\begin{array}{l}\text { Mathias Huebener } \\
\text { Nico A. Siegel } \\
\text { C. Katharina Spiess } \\
\text { Gert G. Wagner } \\
\text { Sevrin Waights }\end{array}$ & $\begin{array}{l}\text { Parental Well-Being in Times of Covid-19 in } \\
\text { Germany }\end{array}$ \\
\hline
\end{tabular}

The Centre for Economic Performance Publications Unit

Tel: +44 (0)2079557673 Email info@cep.lse.ac.uk

Website: http://cep.lse.ac.uk Twitter: @CEP_LSE 